\title{
PENGARUH KEBERADAAN POHON PELINDUNG TERHADAP KONSENTRASI CO DI UDARA AMBIEN ROADSIDE
}

\section{TUGAS AKHIR}

Sebagai salah satu syarat untuk menyelesaikan

Program Strata -1 pada

UNurusan Teknik Lingkungan $4 S$

Fakultas Teknik Universitas Andalas

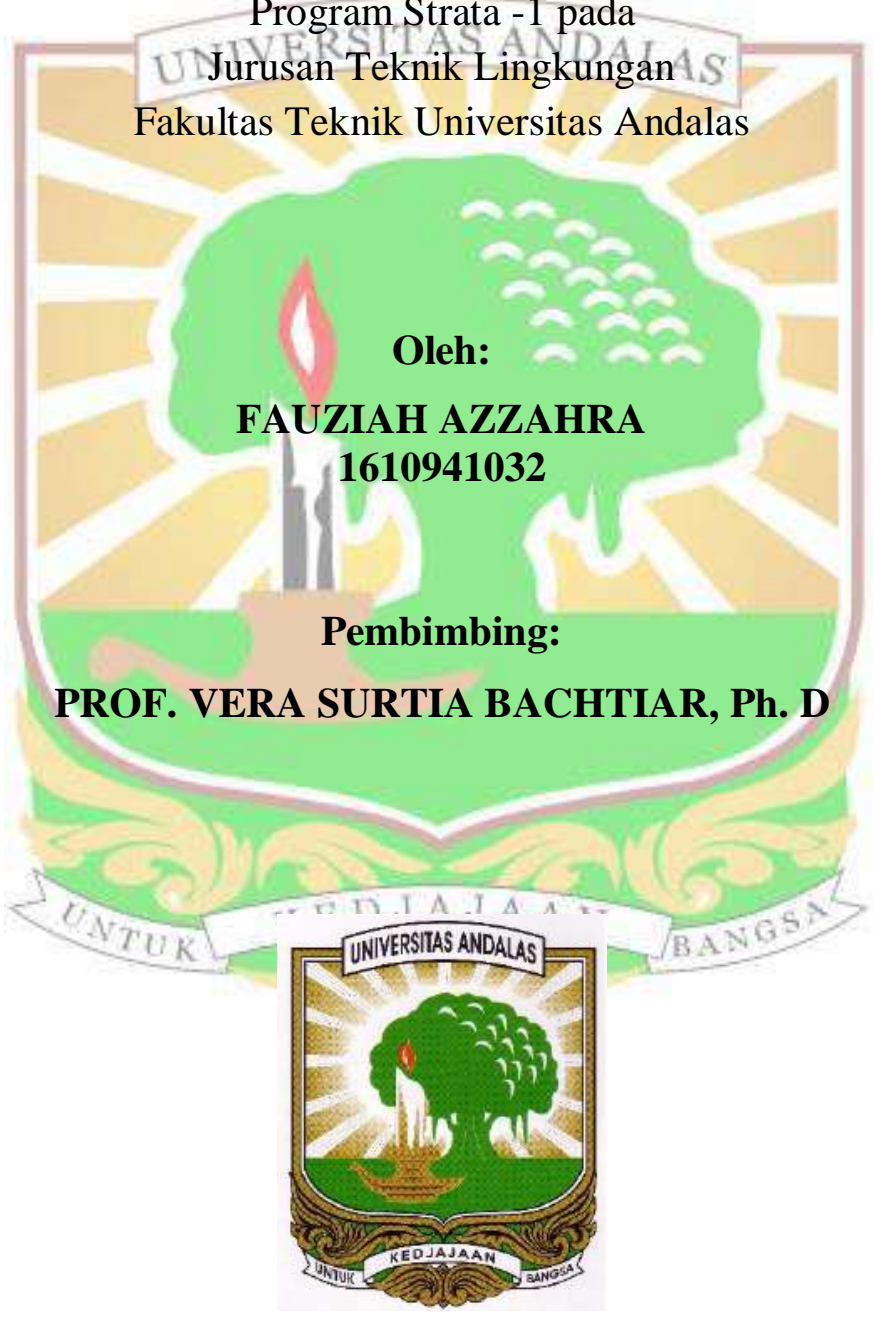

JURUSAN TEKNIK LINGKUNGAN

FAKULTAS TEKNIK-UNIVERSITAS ANDALAS

PADANG

2020 


\section{PERNYATAAN KEASLIAN TUGAS AKHIR}

Dengan ini menyatakan bahwa skripsi yang ditulis dengan judul Pengaruh Keberadaan Pohon Pelindung terhadap Konsentrasi Gas CO di Udara Ambien Roadside adalah benar hasil kerja/karya sendiri dan bukan merupakan tiruan hasil kerja/karya orang lain. Kecuali kutipan pustaka yang subernya dicantumkan. Jika dikemudian hari pernyataan ini tidak benar, maka status kelulusan dan gelar yag saya peroleh menjadi batal dengan sendirinya.

Padang, Agustus 2020

Yang membuat pernyataan

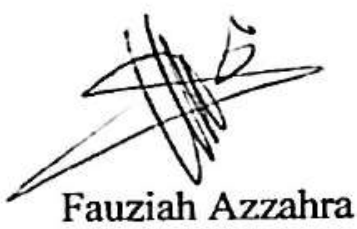




\title{
LEMBAR PENGESAHAN
}

\section{PENGARUH KEBERADAAN POHON PELINDUNG TERHADAP KONSENTRASI CO DI UDARA AMBIEN ROADSIDE}

\author{
Nama : Fauziah Azzahra \\ NIM : 1610941032
}

Lulus Sidang Tugas Akhir tanggal: 6 Agustus 2020

Disetujui oleh:

Pembimbing,

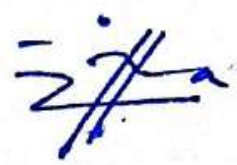

Prof. Vera Surtia Bachtiar, Ph.D

NIP.197108081999032001

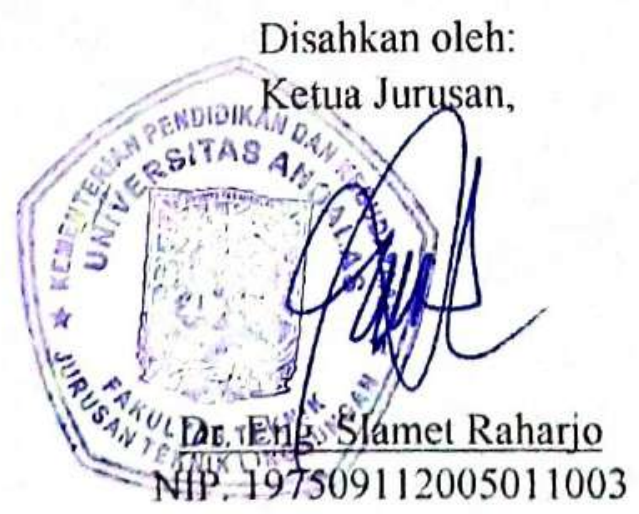




\title{
PENGARUH KEBERADAAN POHON PELINDUNG TERHADAP KONSENTRASI KARBON MONOKSIDA (CO) DI UDARA AMBIEN ROADSIDE
}

\author{
Fauziah Azzahra ${ }^{1}$ Prof. Vera Surtia Bachtiar, Ph.D ${ }^{2}$ \\ ${ }^{1}$ Mahasiswa Jurusan Teknik Lingkungan Universitas Andalas, Padang \\ ${ }^{2}$ Dosen Jurusan Teknik Lingkungan Universitas Andalas, Padang \\ *Email: fauziah.azzahra1707@gmail.com
}

\begin{abstract}
ABSTRAK
Penelitian ini bertujuan untuk menganalisis karakteristik lalu lintas meliputi volume lalu lintas $(V)$, kecepatan lalu lintas (Vk) dan kepadatan lalu lintas (K) terhadap konsentrasi CO serta mempertimbangkan kondisi meteorologi dalam kualitas udara roadside selain itu juga mengkaji dan menganalisis pengaruh keberadaan pohon pelindung dalam mereduksi CO dengan studi kasus di Jalan Prof Hamka dan Jalan Rasuna Said di Kota Padang. Metode yang digunakan dalam penelitian ini adalah kajian literatur. Penelitian ini menggunakan data sekunder yang berasal dari jurnal-jurnal terkait. Data sekunder berupa data karakteristik lalu lintas, data kondisi meteorologi dan data pohon pelindung yang mereduksi CO. Analisis data dilakukan secara deskriptif dengan menganalisis beberapa aspek, diantaranya karakteristik lalu lintas yang memengaruhi CO, faktor meteorologi yang memengaruhi $\mathrm{CO}$ dan pohon pelindung yang dapat mereduksi CO. Hasil dari kajian ini menunjukan bahwa karakteristik lalu lintas sangat memengaruhi kadar CO pada jalan raya. Tingginya volume kendaraan mengakibatkan semakin tinggi pula polusi CO pada udara di sekitar kendaraan dan kondisi meterologi seperti suhu, kecepatan angin dan kelembapan udara memengaruhi konsentrasi $\mathrm{CO}$ di udara roadside. Keberadaan pohon pelindung di studi kasus berpengaruh terhadap penurunan konsentrasi CO. Persentase CO yang direduksi oléh pohon pelindung di Jl Rasuna Said Kota Padang tertinggi ialah $31,8 \%$ terhadap Jl Prof. Hamka. memiliki keberagaman. Kemudian berdasarkan skoring kemampuan pohon pelindung dalam menyerap gas CO, Jl Rasuna Said masuk ke dalam kategori sangat sesuai dengan nilai $88 \%$ sedangkan untuk Jl Prof Hamka masuk ke dalam kategori kurang sesuai dengan nilai 50\%.
\end{abstract}

Kata kunci: konsentrasi CO, pohon pelindung, karakteristik lalu lintas, faktor meteorologi, roadside 


\section{KATA PENGANTAR}

Alhamdulillah, puji syukur Penulis ucapkan kehadirat Allah SWT yang telah memberikan rahmat dan karunia-Nya sehingga Penulis dapat menyelesaikan Proposal Tugas Akhir ini yang berjudul "Pengaruh Keberadaan Pohon Pelindung terhadap Konsentrasi CO di Udara Ambien Roadside". Shalawat serta salam selalu tercurah kepada tauladan sepanjang masa, Nabi Muhammad SAW, beserta para keluarga, sahabat, dan para pengikutnya yang senantiasa istiqomah dalam sunnahnya hingga akhir zaman.

Tugas Akhir ini disusun sebagai salah satu syarat untuk melakukan penelitian Tugas Akhir dalam rangka menyelesaikan program strata satu di Jurusan Teknik Lingkungan Fakultas Teknik Universitas Andalas. Penulis menyadari sepenuhnya bahwa begitu banyak pihak yang telah turut membantu dalam penyelesaianTugas akhirini. Melalui kesempatan ini, dengan segala kerendahan hati, Penulis ingin mengucapkan terima kasih yang sebesar-besarnya kepada:

1. Ayahanda Adrial, Ibu Harpida, Papa Fakhriadi, M.H, Ibu Yermi, S.H, uda-uda Fakhrur Razi dan M. Fauzan Azzima, adik-adik Fadzillah Hariadi dan Fahridh Alhakim, kakak ipar Citra Ayu Riska dan ponakan Keinara Puti Razita yang telah memberikan semangat, motivasi, kasih sayang, pengorbanan serta doadoa yang tulus dan tiada hentinya demi keberhasilan penulis;

2. Ibu Prof. Vera Surtia Bachtiar, Ph.D selaku dosen pembimbing sekaligus motivator bagi penulis yang telah memberikan bimbingan, semangat, dukungan, nasehat, waktu, kemudahan dan doa yang sangat berharga bagi penulis dalam menyelesaikan Tugas Akhir ini;

3. Bapak Dr. Fadjar Goembira dan Bapak Dr. Eng Slamet Raharjo selaku dosen penguji yang telah memberikan saran dan masukan kepada penulis;

4. Bapak Rizki Aziz., Ph.D selaku Ketua Prodi dan Koordinator Tugas Akhir Jurusan Teknik Lingkungan Fakultas Teknik Universitas Andalas yang telah membantu penulis memberikan arahan selama menjalani setiap tahapan Tugas Akhir ini;

5. Bapak Dr. Eng. Slamet Raharjo selaku Ketua Jurusan Teknik Lingkungan; 
6. Bapak dan Ibu staf pengajar beserta karyawan-karyawati Jurusan Teknik Lingkungan Fakultas Teknik Universitas Andalas, serta staf pengajar yang berada di Universitas Andalas yang telah memberikan ilmu dan bantuan kepada penulis;

7. Teman-teman Rangers Dea Salsabilla, Hanny Fauziah Afdal, Khairatul Qalbi, M. Qadri Jakfar dan Vhinta Fadila Erza yang telah meluangkan waktu, fikiran dan dukungan selama pengerjaan Tugas Akhir ini;

8. Teman-teman ma'as dan sopir tembak Rahmadha Yanti, Annisa Agustin, Fiqi Arkan Shadiq, Muhammad Khalil, Mike Marlina, Intania Dwi Ningtias, In Silvia, Safitri Fadilah dan Atika Permata Sari yang telah memberikan dukungan, doa, bantuan selama perkuliahan ini;

9. Rekan-rekan AEROGENIX yang selalu memberikan semangat dan membantu kepada penulis dalam penyelesaian Tugas Akhir ini;

10. Uda, uni, rekan dan adik-adik anggota Himpunan Mahasiswa Teknik Lingkungan (HMTL) Fakultas Teknik Universitas Andalas yang selalu memberikan semangat dan dukungan kepada penulis;

11. Semua pihak yang tidak dapat penulis sebutkan satu per satu yang turut membantu Penulis dalam menyelesaikan Tugas Akhir ini.

Sebagai manusia biasa, tentunya Penulis masih memiliki banyak kekurangan pengetahuan dan pengalaman pada topik yang diangkat dalam Tugas Akhir ini, begitu pula dalam penulisannya yang masih banyak terdapat kekurangan. Oleh karena itu, Penulis menerima berbagai masukan dari para pembaca baik berupa kritik maupun saran yang sifatnya membangun demi penyempurnaan penulisan Tugas Akhir di masa yang akan datang.

Padang, Agustus 2020

Fauziah Azzahra 
ABSTRAK

\section{DAFTAR ISI}

KATA PENGANTAR .................................................................................

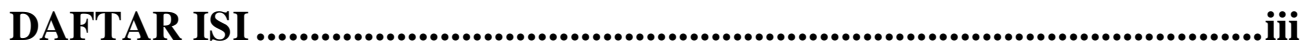

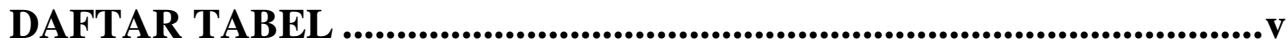

DAFTAR GAMBAR ........................................................................

DAFTAR LAMPIRAN .......................................................................................vii

\section{BAB I PENDAHULUAN}

1.1 Latar Belakang .............................................................................

1.2 Maksud dan Tujuan Penelitian ..........................................................I-3

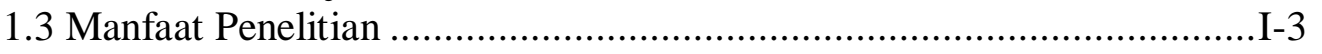

1.4 Ruang Lingkup Penelitian ..............................................................

1.5 Sistematika Penulisan.................................................................

BAB II TINJAUAN PUSTAKASTTAS ANDALAS

2.1 Pencemaran Udara Akibat Transportasi..........................................II-1

2.2 Karbonmonoksida (CO) ...................................................................

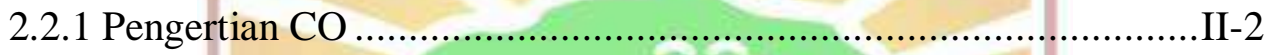

2.2.2 Sumber-sumber $\mathrm{CO}$...............................................................

2.2.3 Dampak Negatif CO .........................................................II-3

2.2.4 Baku Mutu CO di Udara Ambien.................................................II-3

2.3 Karakteristik Lalu Lintas. ................................................................II-4

2.3.1 Volume Lalu Lintas. ...........................................................II-4

2.3.2 Kecepatan Lalu Lintas...........................................................II-6

2.3.3 Kepadatan Lalu Lintas............................................................II-8

2.4 Faktor Meteorologi.....................................................................II-9

2.5 Prinsip Penentuan Lokasi Sampling ................................................II-11

2.6 Pohon Lindung sebagai Reduksi Polutan ........................................II-12

2.6.1 Jenis - Jenis Pohon Lindung yang Mampu Menyerap Polutan. .....II-15

2.6.2 Mekanisme Penjerapan Polutan oleh Tumbuhan.........................II-17

2.6.3 Identifikasi Pohon Pelindung dalam Menyerap Gas Polutan..........II-19

2.7 Penelitian Terkait..........................................................................II-20

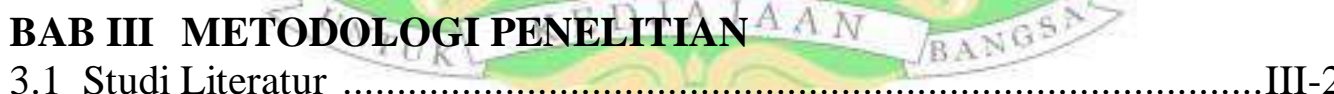

3.2 Pengumpulan Data ......................................................................III-2

3.3 Studi Kasus ......................................................................................III-4

3.4 Perhitungan Persentase Penurunan CO di Studi Kasus...........................III-6

3.5 Analisis Data.......................................................................................III-7

\section{BAB IV PEMBAHASAN}

4.1 Karakteristik Lalu Lintas Memengaruhi Kadar CO ............................IV-1

4.2 Faktor Meteorologi pada Kualitas Udara Roadside ..............................IV-3

4.3 Pengaruh Pohon Pelindung terhadap Konsentrasi CO ...........................IV-7

4.3.1 Peranan Tanaman terhadap Pencemaran Udara di udara roadside .....................................................................IV-10

4.3.2 Pengaruh Penghijauan Dalam Mereduksi CO pada Daerah Traffic Light

4.3.3 Efektivitas Jalur Hijau Jalan dalam 
Mengurangi Polutan Gas CO

IV-13

4.3.4 Pengaruh Tanaman Pelindung Jalan terhadap

Penyebaran Gas Polusi (CO) Lalu Lintas di Daerah Perkotaan .....IV-15

4.3.5 Pengaruh Hambatan Vegetasi berupa Pohon Pelindung

terhadap Konsentrasi CO

IV-16

4.4 Reduksi CO oleh Pohon Pelindung

$. \mathrm{IV}-16$

4.5 Kemampuan Pohon Pelindung dalam Menyerap Konsentrasi CO

di Kota Padang

\section{BAB V PENUTUP}

5.1 Kesimpulan.

5.2 Saran.

61

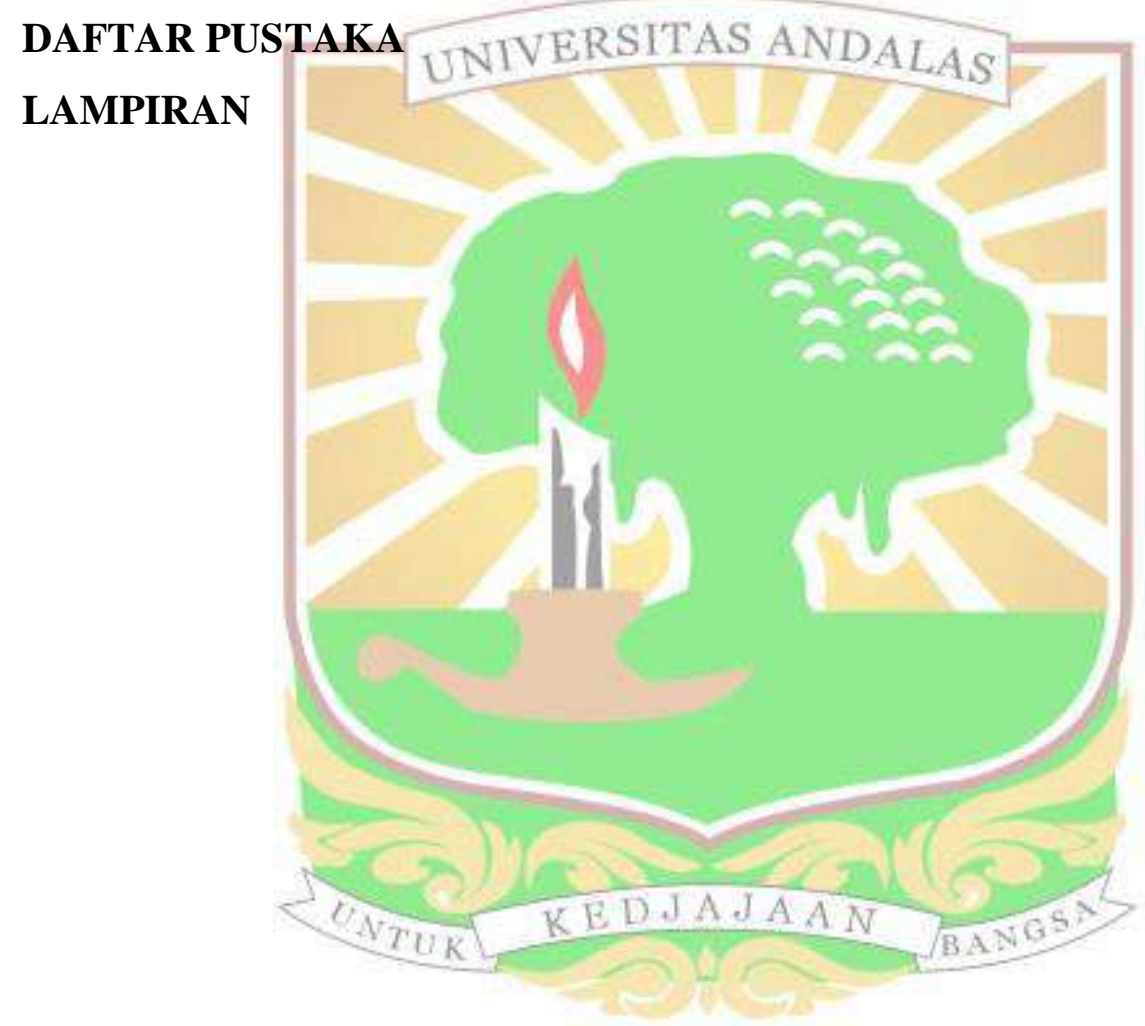




\section{DAFTAR TABEL}

Tabel 2.1 Klasifikasi Kendaraan ..........................................................II-6

Tabel 2.2 Jenis Pohon Lindung Penyerap Polutan......................................II-15

Tabel 2.3 Kriteria Penilaian Ekologis Pohon ..............................................II-19

Tabel 2.4 Pengelompokan Persentase Pembobotan Fungsi Ekologis

Pohon .............................................................................I-20

Tabel 2.5 Hasil Penelitian Kadar $\mathrm{CO}$ dan $\mathrm{NO}_{2}$ pada Jalan Raya yang

Ditanami dan yang Tidak Ditanami Pohon Angsana di Kota

Medan Tahun 2012

Tabel 2.6 Kandungan Timbal antara Daun Glodokan, Angsana dan Mahoni ..................................................................................II-23

Tabel 3.1 Jenis Data Keperluan Penelitian.................................................III-2

Tabel 3.2 Jurnal yang Digunakan dalam Kajian Literatur ..........................III-3

Tabel 3.3 Jenis Jalan Berdasarkan Klasifikasi/ Ruas Jalan di Kota PadangIII-4

Tabel 3.4 Persentase Penurunan CO oleh Jumlah Pohon Pelindung.............III-6

Tabel 4.1 Volume Kendaran di Ruas JI Prof Hamka dan JI Rasuna

Said Kota Padang....................................................................

Tabel 4.2 Data Kepadatan Lalu Lintas di ruas Jalan Prof. Dr. Hamka dan Jalan Rasuna Said Kota Padang …………………………….......IV-2

Tabel 4.3 Data Konsentrasi CO di Jl. Prof. Hamka dan Jl. Rasuna Said Kota Padang................................................................IV-2

Tabel 4.4 Data Kondisi Meteorologi dan Kadar CO di Jl. Prof. Hamka dan Jl. Rasuna Said Kota Padang ..............................................IV-3

Tabel 4.5 Data Kelembapan Udára dan Konsentrasi CO di Jl Prof Dr Hamka Kota Padang .................................................IV-6

Tabel 4.6 Data Konsentrasi CO di Jl Rasuna Said dan Jl Prof Hamka Kota Padang ......................................................................

Tabel 4.7 Data Jumlah Pohon di Ruas Jalan Prof. Hamka dan Jalan Rasuna Said Kota Padang ....................................................IV-8

Tabel 4.8 Data Reduksi CO oleh Pohon Pelindung ……............................IV-9

Tabel 4.9 Jenis dan Jumlah Tanaman Peneduh di Lima Jalan Protokol Kota Semarang ..................................................................

Tabel 4.10 Hasil Pengamatan Kualitas Udara Jalan Protokol Kota Semarang $U K, \ldots$

Tabel 4.11 Kadar CO pada Daerah Traffic light di Jalan Nasional Kota Pontianak ......................................................................

Tabel 4.12 Hasil Uji korelasi Keberadaan Pohon dengan Kadar CO pada Daerah Traffic Light Jalan Nasional Kota Pontianak .................IV-13

Tabel 4.13 Rata - Rata Konsentrasi CO pada Tiga Waktu Dalam Plot Pada Pengambilan Sampel Udara. IV-14

Tabel 4.14 Perubahan Konsentrasi CO pada Jarak 0, 10 dan 30m................IV-14

Tabel 4.15 Pengurangan Konsentrasi CO oleh Pengaruh Vegetasi di Kota Chapel Hill dan Kota Mebane .......................................................IV-16

Tabel 4.16 Rata-rata Konsentrasi CO di Jl Prof Hamka dan Jl Rasuna Said ................................................................................

Tabel 4.17 Skoring Kemampuan Pohon Pelindun dalam Menyerap Polusi di Jl Prof Hamka dan J1 Rasuna Kota Padang IV-18 


\section{DAFTAR GAMBAR}

Gambar 2.1 Ilustrasi Pengukuran Kecepatan dengan Metode Manual ......II-7

Gambar 2.2 Ilustrasi Pengukuran Kecepatan dengan Radar Speed Gun

Meter II-8

Gambar 2.3 Acuan Penentuan Lokasi Pemantauan Kualitas Udara

Roadside

Gambar 2.4 Mekanisme Tanaman dalam Menyerap Polusi.......................II-18

Gambar 3.1 Diagram Alir Tahapan Penelitian ...........................................III-1

Gambar 3.2 Lokasi Penelitian di Jalan Prof Dr. Hamka Kota Padang ........III-5

Gambar 2.3 Lokasi Penelitian di Jalan Rasuna Said Kota Padang ..............III-5

Gambar 4.1 Hasil Pengukuran CO terhadap Keberadaan Vegetasi .............IV-15

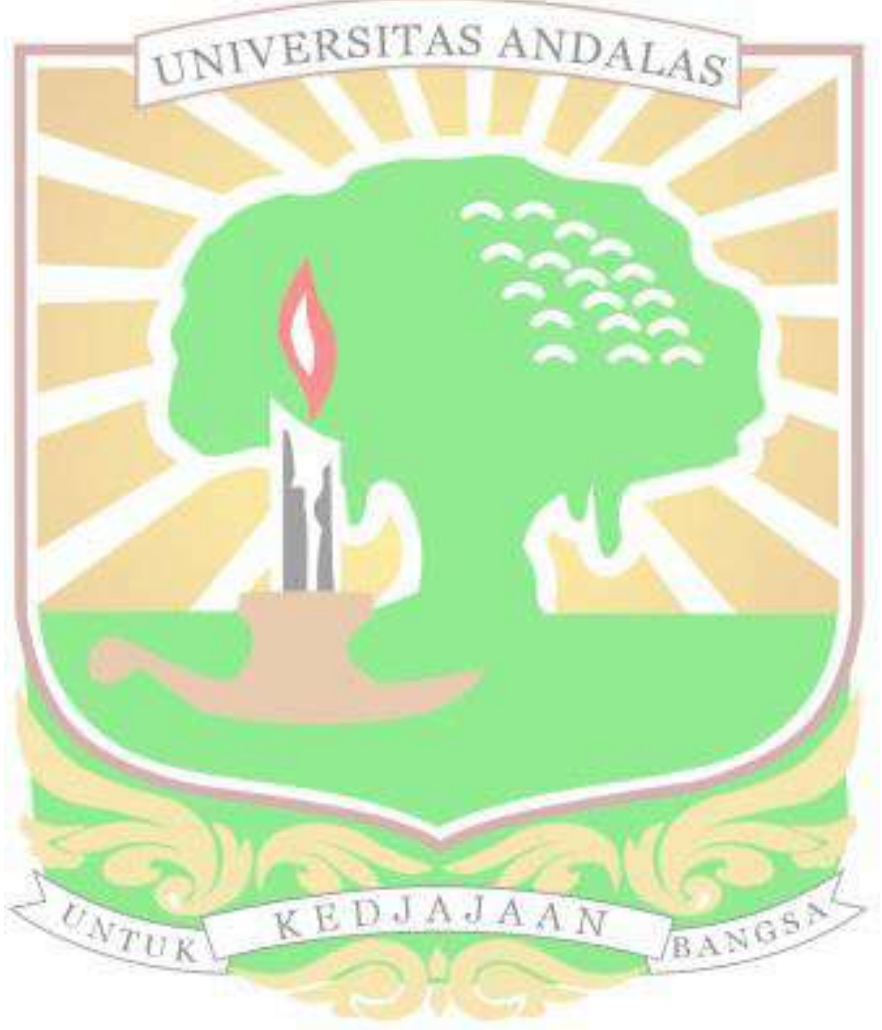




\section{DAFTAR LAMPIRAN}

LAMPIRAN A1 Peraturan Pemerintah RI No. 41 tahun 1999

LAMPIRAN A2 SNI 19-7119.9-2005 tentang Penentuan Lokasi Pengambilan Contoh Uji Pemantauan Kualitas Udara Roadside

LAMPIRAN B Dokumentasi

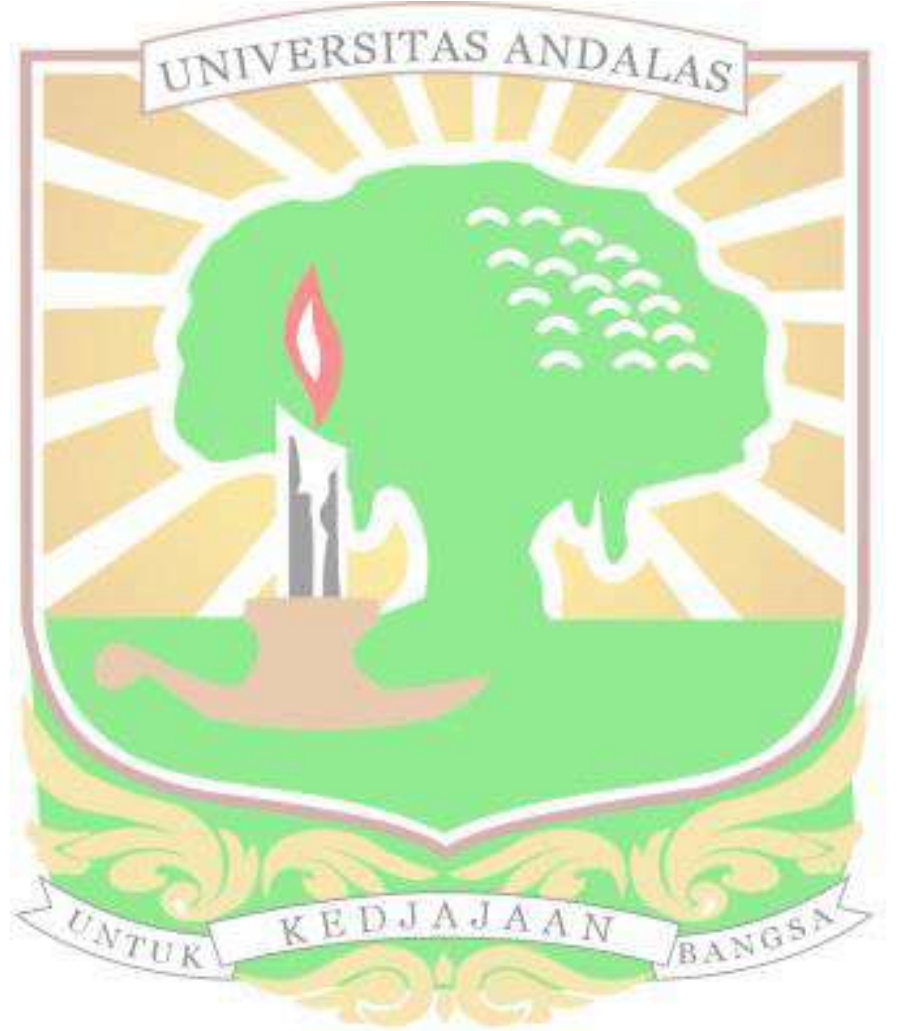




\section{BAB I}

\section{PENDAHULUAN}

\subsection{Latar Belakang}

Pertumbuhan aktivitas ekonomi dan urbanisasi tahun 2019 mencapai 5,17\% di

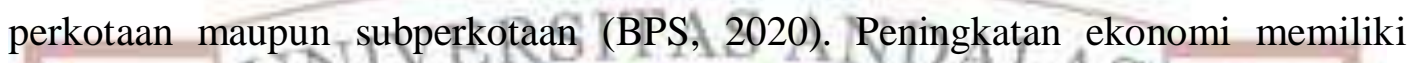
potensi meningkatnya konsumsi energi yang diantaranya konsumsi untuk kebutuhan bahan bakar yang diperlukan untuk sumber dari tenaga listrik, menggerakan perindustrian dan juga sumber bergeraknya transportasi. Pembakaran bahan bakar tersebut adalah salah satu sumber pencemar utama yang dilepaskan ke udara.

Peningkatan aktivitas ekonomi berbanding lurus dengan meningkatnya jumlah kendaraan. Pertumbuhan kendaraan bermotor mencapai 10\% per tahun di Indonesia yang merupakan faktor dominan penyebab utama meningkatnya nilai udara yang tercemar (KemHub, 2012). Pada tahun 2020 setengah dari jumlah penduduk Indonesia akan menghadapi permasalahan pencemaran udara perkotaan, yang didominasi oleh emisi dari kendaraan bermotor.

Kota Padang merupakan salah satu kota di Indonesia yang mengalami meningkatan jumlah kendaraan. Hal ini disebabkan karena Kota Padang adalah satu dari sekian banyak kota yang penduduknya terus meningkat setiap tahun. Tahun 2010 penduduk Kota Padang berjumlah 833.562 orang kemudian di tahun 2019 terjadi peningkatan menjadi 950.871 jiwa. Terjadi peningkatan jumlah penduduk dari tahun 2010 hingga 2019 sebesar 12,34\% (BPS Sumbar, 2020). Peningkatan jumlah penduduk ini berbanding lurus dengan meningkatnya kendaraan di Kota Padang. Terjadi peningkatan sebesar 42,44\% untuk jumlah kendaraan dari di tahun 2014 sampai 2016 di Kota Padang (BPS Kota Padang, 2017). Menurut EPA (2012) akibat dari meningkatnya kendaraan bermotor ialah kualitas udara akan menurun, dapat diartikan bahwa kondisi ini menggambarkan kualitas udara di Kota Padang menurun. Kualitas udara pada suatu kawasan akan menurun yang disebabkan oleh emisi dari kendaraan bermotor. 
Salah satu emisi gas buang kendaraan bermotor adalah Karbon monoksida (CO. CO memiliki karakteristik berupa gas yang tidak berasa, tidak berbau, tidak mengiritasi dan tidak berwarna, tetapi gas $\mathrm{CO}$ mudah terbakar dan merupakan gas yang sangat beracun. Terakumulasinya CO bersama gas lainnya di udara bisa mengakibatkan keracunan bagi manusia. Keracunan bagi manusia dalam bentuk $\mathrm{COHb}$ (Karboksihemoglobin) di dalam darah. Persediaan oksigen yang semakin berkurang ke seluruh tubuh menyebabkan sesak napas mengakibatkan kematian, apabila tidak segera mendapat udara segar kembali (Soedomo, 2001).

Salah satu unsur yang penting di daerah perkotaan ialah jalur hijau. Selain mengontrol polusi yang ada jalur hijau akan menjaga kualitas hidup pada kawasan perkotaan yang polusinya tinggi. Pengurangan polusi oleh tanaman adalah dengan cara dilepaskannya oksigen dari tanaman kemudian akan membuat tercampurnya polutan bersama dengan udara bersih (Grey dan Deneke, 1978). Jalur hijau merupakan satu diantara yang lainnya yang dapat disebut sebagai hutan kota yang ditandai dengan adanya tânaman pohon di pinggir jalan. Terciptanya lingkungan yang menyenangkan bagi pengguna jalan akibat adanya pohon tepi jalan karena mempunyai sifat fisiologis diantaranya kemampuan menyerap polusi juga menghasilkan oksigen (Alhakim, 2014).

Tumbuhan melalui daunnya dapat menangkap partikel timbal yang diemisikan kandaraan bermotor (Siringoringo, 2000). Menurut Martuti (2013) untuk mengurangi semakin tingginya polusi dari kendaraan bermotor, perlu adanya tanaman yang berfungsi sebagai penyerap dan penjerap bahan pencemar dan debu di udara yang dihasilkan kendaraan bermotor. Tanaman peneduh jalan adalah tanaman penghijauan. Tanaman ini memiliki fungsi untuk menyerap secara kimiawi unsur pencemar selain itu memiliki fungsi sebagai pengendalian bising di daerah perkotaan (Agnesia, 2010).

Berdasarkan penelitian Yulfida (2012) reduksi polutan $\mathrm{CO}$ dan $\mathrm{NO}_{2}$ oleh tanaman peneduh jalan di daerah Medan. Konsentrasi $\mathrm{CO}$ dan $\mathrm{NO}_{2}$ pada jalan raya yang ditanami pohon Angsana lebih rendah dibanding konsentrasi $\mathrm{CO}$ dan $\mathrm{NO}_{2}$ di jalan raya yang tidak ditanami pohon Angsana. Konsentrsi CO yang ditanami pohon Angsana rata-rata $10.307 \mu \mathrm{g} / \mathrm{Nm}^{3}$ sedangkan konsentrasi $\mathrm{CO}$ pada jalan raya yang 
tidak ditanami pohon Angsana rata-rata $14.315 \mu \mathrm{g} / \mathrm{Nm}^{3}$. Kadar nitrogen dioksida $\left(\mathrm{NO}_{2}\right)$ tertinggi terdapat pada jalan raya yang tidak ditanami pohon Angsana sedangkan kadar $\mathrm{NO}_{2}$ terendah terdapat pada jalan raya yang ditanami pohon Angsana yaitu $9,80 \mu \mathrm{g} / \mathrm{Nm}^{3}$.

Penelitian Yulfina (2012) membuktikan bahwa pohon pelidung dapat mereduksi polutan yang dihasilkan kendaraan. Maka dari itu peneliti melakukan kajian literatur tentang pengaruh keberadaan pohon pelindung terhadap konsentrasi $\mathrm{CO}$ di Kota Padang. Dilakukan pengumpulan data sekunder yang berasal dari jurnal yang berkaitan dengan penelitian ini yang kemudian akan dianalisis dengan studi kasus yang ada.

\subsection{Maksud dan Tujuan}

Maksud dari tugas akhir ini adalah menganalisis pengaruh tanaman peneduh jalan terhadap konsentrasi gas pencemar, khususnya $\mathrm{CO}$ di udara roadside.

Tujuan tugas akhir ini adalah :

1. Menganalisis pengaruh karakteristik lalu lintas terhadap konsentrasi CO di udara roadside Kota Padang;

2. Menganalisis pengaruh kondisi meterologi terhadap konsentrasi $\mathrm{CO}$ di udara roadside Kota Padang;

3. Mengkaji dan menganalisis pengaruh keberadaan pohon pelindung terhadap konsentrasi CO di udara roadside Kota Padang.

\subsection{Manfaat Penulisan}

Manfaat penulisan Tugas Akhir ini adalah :

1. Hasil penelitian dapat dijadikan acuan dalam penggunaan pohon pelindung untuk mereduksi $\mathrm{CO}$ di udara ambien roadside.

2. Sebagai bahan masukan dan sumbangan pemikiran bagi masyarakat (khususnya pengguna jalan raya) tentang bahaya dari $\mathrm{CO}$ terhadap kesehatan.

3. Menambah wawasan dan pengetahuan bagi penulis tentang perbandingan kandungan kadar CO di udara ambien pada jalan raya dengan adanya keberadaan tanaman peneduh jalan. 


\subsection{Ruang Lingkup}

Ruang lingkup pada tugas akhir ini adalah:

1 Polutan yang dibahas adalah $\mathrm{CO}$ yang berasal dari emisi gas kendaraan bermotor;

2 Data meteorologi (suhu, kelembapan udara, kecepatan angin dan arah angin) memengaruhi kualitas $\mathrm{CO}$ pada pembahasan;

3 Karakteristik lalu lintas (volume kendaraan, kecepatan kendaraan dan kepadatan lalu lintas) menjadi pertimbangan dalam menganalisis konsentrasi CO di udara ambien roadside;

4 Baku mutu udara ambien yaitu Peraturan Pemerintah RI No. 41 Tahun 1999 tentang pengendalian Pencemaran Udara sebagai acuan tingkat tercemarnya udara ambien;

5 Penelitian ini dilakukan berdasarkan kajian literatur atau dengan menggunakan data sekunder dari jurnal yang terbit dalam 10 tahun terakhir terkait reduksi $\mathrm{CO}$ oleh pohon pelindung;

6 Mengkaji perbandingan pengaruh pohon pelindung pada konsentrasi CO pada studi kasus (Jl. Rasuna Said dan Jl. Prof. Hamka Kota Padang) dengan penelitian terkait.

7 Penelitian ini dilakukan dengan membandingkan penelitian terkait reduksi CO oleh pohon pelindung dengan studi kasus di Kota Padang.

\subsection{Sistematika Penulisan}

Sistematika penulisan Tugas Akhir ini adalah:

\section{BAB I PENDAHULUAN}

Bab ini berisikan latar belakang, maksud dan tujuan penelitian, manfaat penelitian, batasan masalah penelitian dan sistematika penulisan.

\section{BAB II TINJAUAN PUSTAKA}

Bab ini berisi tentang dasar-dasar teori dan standar serta peraturan yang digunakan.

\section{BAB III METODOLOGI PENELITIAN}


Bab ini menjelaskan tahapan penelitian yang dilakukan, metode analisis.

\section{BAB IV HASIL DAN PEMBAHASAN}

Bab ini berisikan hasil penelitian disertai dengan pembahasannya.

\section{BAB V PENUTUP}

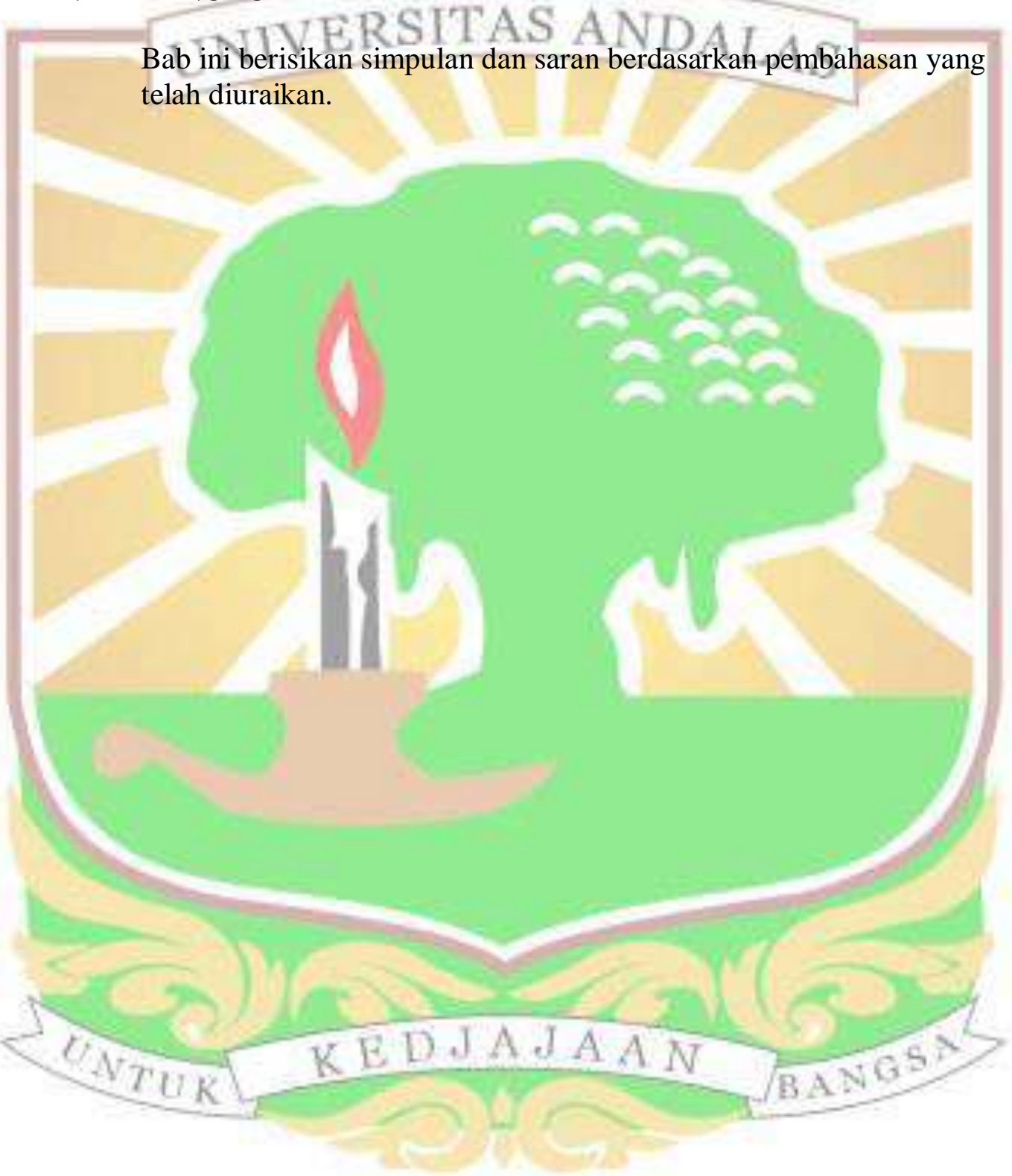




\section{BAB II}

\section{TINJAUAN PUSTAKA}

\subsection{Pencemaran Udara Akibat Transportasi}

Kendaraan bermotor adalah sumber polutan terbesar, $98 \%$ polutan udara berasal dari kendaraan bermotor di kota besar (European Environment Agency atau EEA, 2017). meningkatnya penggunaan bahan berbanding lurus bersama meningkatnya penggunaan kendaraan. Jumlah kendaraan meningkat cukup pesat di daerah perkotaan, oleh karena itu penggunaan dari bahan bakar akan meningkat semakin tinggi (Departement of Transport $U K$, 1994): Diperkirakan bahwa pada tahun 2012, polusi udara mengakibatkan $72 \%$ kematian dini karena terserang penyakit jantung dan stroke, 14\% kematian karena terserang penyakit infeksi saluran pernapasan akut (chronic obstructive pulmonary disease) dan $14 \%$ kematian lainnya karena penyakit kanker paru-paru (WHO, 2012). Emisi gas buang berupa asap knalpot adalah akibat terjadinya proses pembakaran yang tidak sempurna, dan mengandung timbal/timah hitam ( $\mathrm{Pb})$, suspended particulate matter (SPM), oksida nitrogen (NOx), oksida sulfur (SOx), hidrokarbon (HC), CO dan oksida fotokimia (Ox) (BPLH DKI Jakarta, 2013).

\section{$2.2 \mathrm{CO}$}

Menurut Siswantoro (2012) akibat dari pembakaran yang tidak sempurna ataupun karena campuran bahan bakar dan udara yang terlalu tinggi (kurangnya udara) akan membentuk CO. Perbandingan campuran bahan bakar dan udara yang dihisap oleh mesin akan mempengaruhi $\mathrm{CO}$ yang dikeluarkan dari sisa hasil pembakaran tersebut, untuk mengurangi $\mathrm{CO}$ perbandingan dicampur dengan baik, tetapi cara ini mempunyai efek samping yang lain, yaitu NOx akan lebih mudah timbul dan tenaga yang dihasilkan mesin akan berkurang.

\subsubsection{Pengertian CO}

Gas yang tidak berwarna, tidak berbau, tidak berasa, tidak mengiritasi, mudah terbakar dan sangat beracun, serta tidak larut dalam air merupakan pengertian dari CO. Gas ini merupakan hasil pembakaran tidak sempurna dari kendaraan bermotor, alat pemanas dan peralatan yang menggunakan bahan api. Senyawa CO 
mempunyai potensi bersifat racun yang berbahaya terhadap manusia, karena mampu membentuk ikatan yang kuat dengan pigmen darah yaitu hemoglobin (Dharmawan dan Susanti, 2012)

Pada suhu di bawah $-129^{\circ} \mathrm{C}$ gas $\mathrm{CO}$ dapat berbentuk cairan. Gas $\mathrm{CO}$ sebagian besar berasal dari pembakaran bahan fosil dengan udara berupa gas buangan. Kadar CO dalam udara perkotaan relatif tinggi dibandingkan dengan daerah pedesaan disebabkan karena di kota besar yang padat lalu lintasnya akan banyak menghasilkan gas CO sehingga. Selain itu, gas CO dapat pula terbentuk dari proses industri yang berasal dari asap hasil produksi pada industri, contohnya pada industri pengapasan ikan (Saputra,2009)AS ANDALAS

\subsubsection{Sumber CO}

Sumber utama dari gas CO berasal dari pembakaran yang tidak sempurna oleh kendaraan bermotor yang berada di ruas jalan raya, selain itu kemacetan lalu lintas juga akan menambah beban pencemar ke udara (Fardiaz, 2010). Konsentrasi CO akan meningkat pada ruas jalan raya yang macet karena pada saat tersebut kendaraan bergerak lambat bahkan berhenti dan tetap mengeluarkan emisi. Lokasi kemacetan lalu lintas adalah daerah dimana tingkat polusi yang tinggi.

Emisi gas CO di kota-kota Amerika Serikat berkontribusi sebesar 75\% sampai 95\% yang dihasilkan oleh gas buang kendaran. Ketel uap, proses industri, pembuangan limbah dan lain-lain merupakan sumber lain dari emisi gas CO (EPA, 2012). CO berasal dari pembakaran tidak sempurna bensin di dalam mobil, pembakaran di perindustrian, pembangkit listrik, pemanas timah, pembakaran di pertanian dan sebagainya. CO dapat juga dihasilkan dari reaksi oksidasi gas metana oleh radikal hidroksi dan dari perombakan/pembusukan tanaman meskipun tidak sebesar yang dihasilkan oleh bensin (BLH Kab. Bantul, 2013).

Suhu yang tinggi memicu terjadinya gas CO karena hasil pembakaran dengan suhu yang tinggi menyebabkan jumlah dari gas $\mathrm{CO}$ semakin banyak karena proses disosiasi $\mathrm{CO}$ dan O. Penemuan baru menyatakan bahwa tanah terbuka yang belum terdapat bangunan diatasnya cukup efektif menyerap $\mathrm{CO}$, hal ini disebabkan oleh penyerapan gas $\mathrm{CO}$ oleh mikroorganismse di dalam tanah. Pengurangan $\mathrm{CO}$ dapat 
terjadi oleh angin karena polutan $\mathrm{CO}$ akan dibawa oleh angin menuju tempat lain (Mulianto, 2005).

\subsubsection{Dampak Negatif CO}

Konsentrasi gas CO yang tinggi dapat menyebabkan gangguan kesehatan, bahkan juga dapat menyebabkan kematian. Apabila gas CO terhisap ke dalam paru-paru maka akan menghalangi masuknya oksigen $\left(\mathrm{O}_{2}\right)$ karena gas $\mathrm{CO}$ mengikuti peredaran darah dan oksigen $\left(\mathrm{O}_{2}\right)$ dibutuhkan oleh tubuh. Dampak negatif ini dapat terjadi karena gas CO ikut bereaksi secara metabolis dengan darah menjadi karboksihemoglobin $(\mathrm{COHb})$ karena itu gas $\mathrm{CO}$ disebut gas yang bersifat racun metabolis. Kestabilan dari ikatan karboksihemoglobin jauh lebih tinggi dari pada oksihemoglobin atau ikatan oksigen dengan darah. Keadaan ini menyebabkan CO lebih mudah ditangkap pleh darah sehingga fungsi vital darah sebagai pengangkut oksigen terganggu akibat hal tersebut(Yulianti, 2013).

Pada umumnya saluran pernapasan atau rute terhirup atau inhalasi (inhalationroute) merupakan rute keterpajanan gas CO. Gas CO masuk ke dalam kelompok bahan kimia asfiksia (asphyxiate). Gas CO menyebabkan tubuh mengalami kekurangan oksigen dan gejala asfiksia atau kekurangan oksigen akan terjadi. Hal ini disebabkan afinitas atau sifat pengikatan atau daya lengket $\mathrm{CO}$ ke hemoglobin darah dibandingkan dengan oksigen jauh lebih besar sebanyak 200 3.000 kali lipat. Dalam jumlah sedikit pun gas CO jika terhirup dalam waktu tertentu dapat menyebabkan gejala racun terhadap tubuh (Majid, 2011).

Paparan udara dengan gas CO dapat mengakibatkan keracunan sistem saraf dan jantung. Keracunan ini terjadi jika paparan gas CO melampui batas dari yang bisa terjadi ditoleransi tubuh, yaitu lebih dari 250 ppm (Rezki dkk, 2012). Keracunan gas CO sulit untuk dideteksi karena gejalanya yang bersifat umum dan mirip dengan gejala flu. Tetapi paparan gas CO pada dosis tinggi dapat memengaruhi otak, menyebabkan mual, dan kematian (Mukono, 2011).

\subsubsection{Baku Mutu CO di Udara Ambien}

Setiap parameter memiliki baku mutu udara sesuai ketentuan. Ketentuan baku mutu udara ambien terdapat dalam Peraturan Pemerintah No. 41 Tahun 1999 tentang Pengendalian Pencemaran Udara. Menurut Peraturan Pemerintah No. 41 Tahun 
1999, baku mutu udara ambien adalah ukuran batas atau kadar zat, energi, dan/ atau komponen yang ada atau yang seharusnya ada dan/ atau unsur pencemar yang ditenggang keberadaannya dalam udara ambien. Baku mutu udara ambien nasional ditetapkan sebagai batas maksimum mutu udara ambien untuk mencegah terjadinya pencemaran udara. Baku mutu udara ambien untuk parameter CO pada waktu pengukuran 1 jam sebesar $30.000 \mu \mathrm{g} / \mathrm{Nm}^{3}$ dan waktu pengukuran 24 jam sebesar $10.000 \mu \mathrm{g} / \mathrm{Nm}^{3}$.

\subsection{Karakteristik Lalu Lintas}

Pergerakan individu pengendara yang melakukan interaksi antara yang satu dengan yang lainnya pada suatu ruas jalan dan lingkungannya membentuk arus lalu lintas. Akibat persepsi dan kemampuan individu pengemudi mempunyai sifat yang berbeda maka perilaku kendaraan arus lalu lintas tidak dapat diseragamkan lebih lanjut, arus lalu lintas akan mengalami perbedaan karakteristik akibat dari perilaku pengemudi yang berbeda yang dikarenakan oleh karakteristik lokal dan kebiasaan pengemudi (Nevers, 2017). Berikut beberapa parameter maupun variabel yang bisa dipergunakan untuk menjelaskan bagaimana karakteristik lalu lintas, diantaranya (MKJI, 1997):

1. Volume (q);

2. Kecepatan (v); dan

3. Kepadatan $(\mathrm{k})$.

\subsubsection{Volume Lalu Lintas}

Volume adalah besarnya jumlah kendaraan yang diamati melalui suatu titik tertentu dari suatu ruas jalan selama kisaran waktu tertentu. Biasanya volume lalu lintas dinyatakan oleh satuan kendaraan/jam (smp/jam) atau kendaraan/hari (smp/hari). Satuan mobil penumpang (smp) merupakan satuan arus lalu lintas, yang mana arus yang berasal dari berbagai tipe kendaraan sudah diubah ke kendaraan ringan (termasuk mobil penumpang) dengan memakai ekivalensi mobil penumpang (emp) (MKJI, 1997). Ketika suatu titik semakin banyak dilewati kendaraan tentu saja besar volume lalu lintas semakin besar pada titik tersebut. Pada suatu jalan, volume kendaraan yang terjadi bisa berubah-ubah berdasarkan suatu pola yang tetap. Berikut pembagian dari volume (Morlock, 1991): 
1. Volume harian (daily volumes)

Penggunaan volume harian adalah untuk perencanaan jalan juga sebagai observasi umum mengenai trend pengukuran volume. Beberapa perbedaan dalam pengukuran volume harian ini, yaitu:

a. Average Daily traffic (ADT), adalah volume yang diukur selama 24 jam penuh dalam periode waktu tertentu dan dibagi berdasarkan banyaknya hari tersebut.

b. Average Annual Daily Traffic (AADT), merupakan pengukuran volume dalam 24 jam selama kurun waktu 365 hari, dengan demikian total kendaraan yang dibagi 365 hari;

2. Volume jam-an (hourly volumes)

Volume jam-an merupakan arus lalu lintas yang diamati untuk mengetahui jam puncak selama periode pagi dan sore. Berdasarkan pengamatan ini bisa ditentukan arus terbesar atau arus pada jam puncak. Arus di jam puncak ini digunakan untuk dasar mendesain jalan raya juga menganalisis operasi lainnya yang diperlukan misalnya menganalisis keselamatan.

Secara umum, pengelompokan kendaraan yang beroperasi di jalan raya menjadi beberapa kategori (MKJI, 1997):

\section{Kendaraan tak bermotor (UM)}

Kendaraan tipe ini memiliki roda yang digerakkan oleh manusia atau hewan, meliputi sepeda, becak, kereta kuda, dan kereta dorong.

2. Motor Cycle (MC) (MC) ZUK

Motor Cycle atau kendaraan bermotor merupakan kendaraan yang memiliki 2 atau 3 roda, contohnya sepeda motor dan kendaraan roda 3;

\section{Heavy Vehicle (HV)}

Heavy vehicle atau kendaraan berat adalah kendaraan bermotor dengan lebih dari 4 roda meliputi bus dan truk;

\section{Light Vehicle (LV)}

Light vehicle atau kendaraan ringan adalah kendaraan bermotor ber as dua dengan empat roda dan dengan jarak as 2,0-3,0 m. Kendaraan ini meliputi mobil penumpang, microbus, pick up, dan truk kecil; 
Sesuai dengan Manual Kapasitas Jalan Indonesia (MKJI, 1997), klasifikasi kendaraan dibagi seperti yang terdapat pada Tabel 2.1.

Tabel 2.1 Klasifikasi Kendaraan

\begin{tabular}{|c|c|c|c|}
\hline No & $\begin{array}{c}\text { Jenis } \\
\text { Kendaraan }\end{array}$ & Definisi & Contoh \\
\hline 1 & $\begin{array}{l}\text { Kendaraan } \\
\text { Ringan (Light } \\
\text { Vehicles) }\end{array}$ & $\begin{array}{l}\text { Kendaran bermotor ber as dua } \\
\text { dengan } 4 \text { roda dengan jarak as } 2,0- \\
3,0 \mathrm{~m} \text {. }\end{array}$ & $\begin{array}{l}\text { Mobil penumpang, oplet, } \\
\text { mikrobis dan pick up. }\end{array}$ \\
\hline 2 & $\begin{array}{l}\text { Kendaraan Berat } \\
\text { (Heavy } \\
\text { Vehicles) }\end{array}$ & $\begin{array}{l}\text { Kendaraan bermotor dengan lebih } \\
\text { dari } 4 \text { roda. }\end{array}$ & $\begin{array}{l}\text { Bus, truk } 2 \text { as, truk } 3 \text { as dan } \\
\text { truk kombinasi dan truk kecil. }\end{array}$ \\
\hline 3 & $\begin{array}{l}\text { Sepeda Motor } \\
\text { (Motorcycle) }\end{array}$ & $\begin{array}{l}\text { Kendaraan bermotor dengan } 2 \text { atau } \\
3 \text { roda IVERSITAS ANDAL }\end{array}$ & $\begin{array}{l}\text { Sepeda motor dan kendaraan } \\
\text { roda } 3\end{array}$ \\
\hline 4 & $\begin{array}{l}\text { Kendaraan Tak } \\
\text { Bermotor }\end{array}$ & $\begin{array}{l}\text { Kendaran dengan roda yang } \\
\text { digerakkan oleh orang atau hewan }\end{array}$ & $\begin{array}{l}\text { Sepeda, becak, kereta kuda } \\
\text { dan kereta dorong }\end{array}$ \\
\hline
\end{tabular}

Sumber: Manual Kapasitas Jalan Indonesia, 1997

Berdasarkan MKJI (1997), volume lalu lintas didapatkan melalui normalisasi pada persamaan berikut:

$q=(n L V \times f L V)+(n H V \times f H V)+(n M C \times f M C)$

Keterangan:

$\mathrm{q} \quad=$ volume lalu lintas (smp/jam)

$\mathrm{nLV} \quad=$ jumlah kendaraan yang lewat per jam untuk setiap jenis kendaraan light vehicle

$\mathrm{nHV}=$ jumlah kendaraan yang lewat per jam untuk setiap jenis kendaraan heavy vehicle

$\mathrm{nMC}=$ jumlah kendaraan yang lewat per jam untuk setiap jenis kendaraan motor cycle

$\mathrm{fLV} \quad=$ nilai $\mathrm{emp}=1$ untuk jenis kendaraan light vehicle

$\mathrm{fHV}=$ nilai $\mathrm{emp}=1,2$ untuk jenis kendaraan heavy vehicle

$\mathrm{f} \mathrm{MC}=$ nilai $\mathrm{emp}=0,25$ untuk jenis kendaraan motor cycle.

\subsubsection{Kecepatan Lalu Lintas K E D J A I A A N}

Kecepatan lalu lintas kendaraan didefinisikan sebagai perbandingan antara jarak yang ditempuh dengan waktu yang diperlukan untuk menempuh jarak tersebut. Berdasarkan jenis waktu tempuh, kecepatan dapat dibedakan atas (Hobbs, 1995):

1. Kecepatan setempat adalah kecepatan kendaraan pada suatu saat diukur dari suatu tempat yang ditentukan;

2. Kecepatan bergerak adalah perbandingan antara jumlah jarak yang ditempuh dengan waktu selama dalam keadaan bergerak;

3. Kecepatan perjalanan adalah perbandingan antara jumlah jarak yang ditempuh dengan waktu perjalanan yang digunakan menemuh jarak tertentu. 
Kecepatan adalah sebagai rasio jarak yang dijalani dan waktu perjalanan. Hubungan yang ada dapat dilihat dalam persamaan berikut ini (Hobbs, 1995):

$\mathrm{V}=\frac{\mathrm{S}}{\mathrm{t}}$

Keterangan:

$\mathrm{V}=$ Kecepatan perjalanan $(\mathrm{km} / \mathrm{jam})$

$\mathrm{s}=$ Jarak perjalanan $(\mathrm{km})$

$\mathrm{t}=$ Waktu perjalanan $(\mathrm{jam})$

Berdasarkan Peraturan Menteri Negara Lingkungan Hidup (2010), metode pengukuran kecepatan memiliki 2 jenis metode pengukuran, yaitu:

1. Pengukuran tak langsung

Gambar ilustrasi pengukurạn metode manual bisa dilihat pada Gambar 2.1

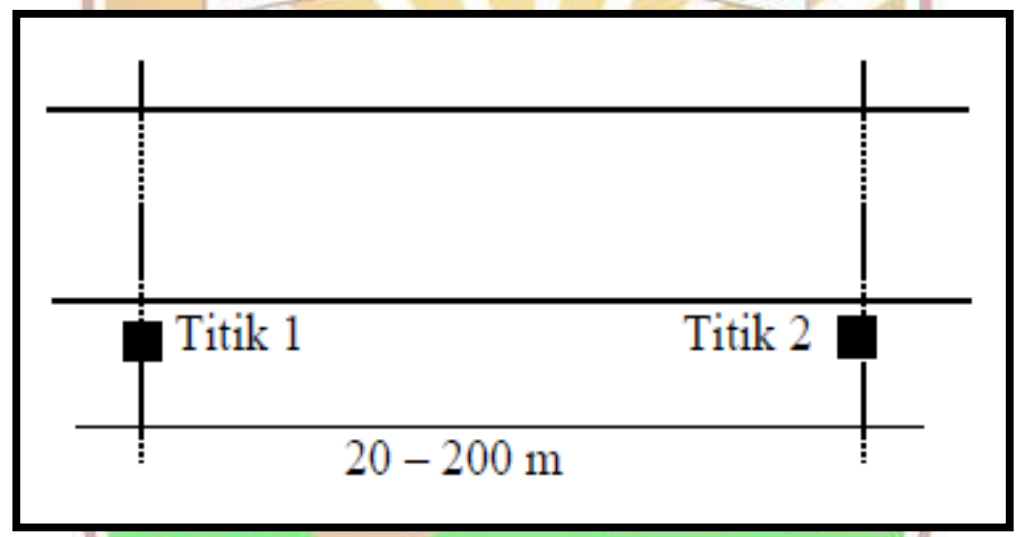

Gambar 2.1 Ilustrasi Pengukuran Kecepatan dengan Metode Manual

Sumber: Peraturan Menteri Negara Lingkungan Hidup Nomor 12, 2010

Pengukuran tak langsung ialah pengukuran dengan cara memperoleh waktu tempuh hasil pengamatan. Metode dua pengamat (manual) merupakan salah satu contoh dari metode pengukuran tak langsung. Cara memperoleh metode manual adalah dengan cara menghitung waktu yang ditempuh oleh suatu kendaraan melewati dua titik dengan jarak sekitar 20-200 m. Ketika titik pertama, kendaraan berjalan, pengamat ke-1 menurunkan tangan dan pengamat ke-2 menjalankan stopwatch serta menghentikan stopwatch ketika kendaran melewati titik kedua, atau dengan cara memberikan tanda patok pada titik pertama dan titik kedua yang diberikan jarak sekitar 20-200 m, lalu ketika kendaraan melewati kedua titik tersebut makan akan dihitung waktu tempuh kendaraan. 
2. Pengukuran langsung

Pengukuran langsung adalah kecepatan yang diukur dengan cara langsung di lapangan, contoh metode pengukuran langsung salah satunya yakni menggunakan speed gun. Alat ini bisa dipegang langsng menggunakan tangan, selain itu dipasang di kendaraan dan bisa juga dengan diletakkan pada tripod. Gelombang mikro berupa frekuensi yang tinggi yang berasal dari alat dihantarkan ke arah kendaraan yang bergerak. Kemudian kendaraan memantulkan gelombang ke alat speed gun ini. Berubahnya frekuensi gelombang hantar dengan gelombang pancar dapat dikatakan sebanding bersama kecepatan kendaraan yang relatif terhadap radar meter. Gambar ilustrasi pengukuran dengan radar gun meter dapat dilihat pada Gambar 2.2.

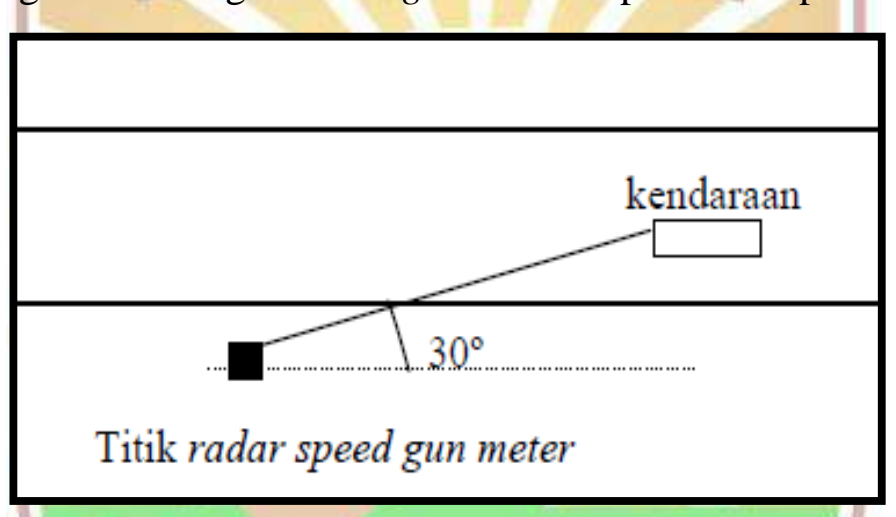

Gambar 2.2 Ilustrasi Pengukuran Kecepatan dengan Radar Speed Gun Meter Sumber: Peraturan Menteri Negara Lingkungan Hidup Nomor 12, 2010

\subsubsection{Kepadatan Lalu Lintas}

Kepadatan lalu lintas merupakan pengertian dari berapa jumlah kendaraan yang menempati suatu panjang jalan maupun lajur, biasanya diekspresikan terhadap kendaraan per kilometer. Kepadatan lalu lintas definisi dari jumlah kendaraan yang lewat di suatu jalan tertentu dari sebuah jalur dalam satu atau dua arah selama jangka waktu yang ditentukan. Kepadatan lalu lintas sukar diukur secara langsung di lapangan, melainkan dihitung dari nilai kecepatan dan arus seperti persamaan di bawah ini (Morlock, 1991):

$\mathrm{V}=\mathrm{Dx} \mathrm{S}$

$\mathrm{D}=\mathrm{V} / \mathrm{S}$

Keterangan:

$\mathrm{D} \quad=$ Kepadatan kendaraan $($ kendaraan $/ \mathrm{km})$

$\mathrm{V} \quad=$ Volume kendaraan (kendaraan/jam) 


\subsection{Faktor Meteorologi}

Faktor meteorologi, iklim dan faktor topografi merupakan beberapa faktor yang memengaruhi pencemaran udara yang terjadi di permukaan bumi (Chandra, 2007). Langkah-langkah dalam pengendalian pencemaran udara dari berbagai sumber pencemar baik industri maupun sistem transportasi dapat diketahui melalui informasi meteorologi yang ada. Oleh karena itu meteorologi menjadi faktor penting yang dipelajari (Istirokhatun dkk, 2016).

Adapun parameter meteorologi yang penting diperhatikan dalam pecemaran udara adalah sebagai berikut: UNTVERSITAS ANDALAS

\section{Suhu Udara}

Suhu udara merupakan ukuran yang menyatakan panas, dingin atau sejuknya kondisi yang dirasakan bumi. Suhu udara menurun $\pm 1{ }^{\circ} \mathrm{C}$ per kenaikan ketinggian 100 meter, namun pada malam hari lapisan udara yang dekat dengan permukaan bumi mengalami pendinginan terlebih dahulu sehingga suhu pada lapisan udara di lapisan bawah dapat lebih rendah daripada atasnya (Sastrawijaya, 2009).

Suhu berbanding lurus dengan konsentrasi partikel. Hal ini disebabkan pada suhu yang tinggi kecepatan partikel mengendap menjadi lebih lambat, karena pada suhu tinggi pertikel debu menjadi lebih ringan sehingga akan lebih lama berada di udara dalam keadaan turbulen. Sebaliknya pada suhu rendah, kecepatan mengendap partikel menjadi lebih cepat, karena pada suhu rendah pertikel debu menjadi lebih berat sehingga sehingga partikel debu yang terhisap oleh alat menjadi lebih sedikit (Nisalah dkk, 2010).

\section{Kelembapan Udara}

Kelembapan udara yaitu ukuran yang menyatakan banyaknya massa jenis uap air yang terkandung dalam satu satuan volume udara, sedangkan kelembapan relatif yaitu perbandingan antara uap air yang benar-benar ada di udara dengan jumlah uap air dalam udara tersebut (Tjasyono, 2004). Suhu udara akan berbanding lurus dengan kelembapan udara, hal ini dikarenakan pada suhu yang tinggi, udara akan mengalami perenggangan, sehingga udara yang merenggang 
tersebut akan diisi oleh uap-uap air. Kondisi udara yang lembab akan membantu proses pengendapan bahan pencemar, sebab dengan keadaan udara yang lembab maka beberapa bahan pencemar berbentuk partikel akan berikatan dengan air yang ada dalam udara dan membentuk partikel yang berukuran lebih besar sehingga mudah mengendap.

\section{Tekanan Udara}

Tekanan udara adalah gaya yang ditimbulkan akibat berat lapisan udara. Besarnya tekanan udara tersebut dinyatakan dalam 1 atm. Suatu reaksi kimia antara zat pencemar dengan zat pencemar di udara atau zat-zat yang ada di udara daoat dipercepat ataupun diperlambat Sakibat adanyatekanan udara, sehingga pencemar di udara dapat berkurang atau bertambah (Junaidi, 2002). Tekanan udara berbanding terbalik dengan suhu, dikarenakan ketika suhu tinggi, udara akan merenggang dan tekanan udara menjadi lebih rendah dan begitu sebaliknya.

\section{Angin}

Distribusi pencemar dipengaruhi oleh kecepatan dan arah angin, jika angin bertiup kencang konsentrasi pencemar akan berkurang dan membagikan pencemar secara mendatar dan tegak lurus. Menurut Chandra (2007), angin dengan kecepatan yang kuatakan membawa polutan terbang ke tempat lain dan dapat mencemari udara negara lain. Pergerakan udara akan mengakibatkan terjadinya proses penyebaran sehingga terjadi pengenceran dari bahan pencemar udara, akibatnya kadar suatú pencemar pada jarak tertentu dari sumber akan mempunyai konsentrasi pencemar yang berbeda. Demikian juga halnya dengan arah dan kecepatan angin dapat memengaruhi kadar pencemar setempat. Konsentrasi bahan pencemar dari sumber secara terus menerus berhubungan dengan kecepatan angin. Semakin tinggi kecepatan angin, akan menyebabkan konsentrasi partikel semakin kecil dikarenakan penyebaran partikel atau molekul semakin besar. Dengan kata lain angin yang sangat kencang serta bergolaknya kuat menyebabkan konsentrasi pencemar menjadi semakin encer, sedangkan angin yang reda dan bergolak lemah menyebabkan konsentrasi pencemar menjadi pekat (Supriyadi, 2009). 
5. Hujan

Hujan merupakan salah satu faktor meteorologi yang dapat memengaruhi konsentrasi pencemar di udara. Hujan adalah suatu partikel air di udara yang bergerak dari atas jatuh ke permukaan bumi sehingga mampu menyerap pencemar gas tertentu ke dalam partikel air, serta dapat menangkap partikel debu yang inert maupun partikel debu yang lain. Debu akan menempel pada partikel air dan dibawa jatuh ke bumi. Dengan demikian akibat jatuhnya hujan, pencemar dalam bentuk partikel dapat berkurang konsentrasinya di udara (Junaidi, 2002).

\subsection{Prinsip Penentuan Lokasi Sampling ANDALAS}

Berdasarkan SNI 19-7119.9-2005 tata cara milihan lokasi serta menentuan titik sampling, hendaklah mewakili lokasi yang sedang dilakukan pemantauan, karenanya hasil yang diukur akan memperoleh gambaran bagaimana kondisi kualitas pada daerah penelitian. Beberapa syarat guna memilih lokasi dan titik sampling menurut SNI 19-7119.9-2005 adalah dengan cara memilih lokasi pengambilan sampel roadside, kemudian menempatkan alat pengambil sampel yang alirannya bebas dengan mempertimbangkan pengaruh proses penjerapan maupun penyerapan. Penempatan alat sampling hendaknya di daerah aman dan bebas dari hal-hal yang dirasa akan mengganggun, selain itu hendaknya juga terhindar dari bahaya kerusuhan juga bencana alam serupa banjir dan longsor. Penempatan alat juga harus memperhatikan tipe jalan (lebar, sempit, canyon atau jalan tol, demikian juga persimpangan jalan ataupun perhentian kendaraan).

Langkah-langkah dalam pengambilan sampel berdasarkan SNI 19-7119.9-2005 adalah:

1. Menempatkan peralatan pengambil sampel pada lokasi yang mempunyai prasarana seperti listrik;

2. Menempatkan peralatan pengambil sampel di daerah terbuka (gedung atau bangunan yang rendah dan saling berjauhan). Peralatan ditempatkan $1 \mathrm{~m}$ sampai dengan $5 \mathrm{~m}$ dari pinggir jalan yang akan diambil sampel dan pada ketinggian 1,5 m sampai dengan $3 \mathrm{~m}$ dari permukaan jalan; 
3. Mengukur kepadatan lalu lintas dari jalan yang akan diambil sampel, kemudian mengategorikan kepadatan lalu lintas (kurang 2.000, 2.000-10.000 dan lebih dari 10.000 kendaraan per hari).

Roadside adalah tepi jalan raya yang secara langsung memengaruhi pencemaran udara sumber bergerak yang disebabkan oleh aktivitas kendaraan bermotor. Berdasarkan SNI 19-7119.9-2005, untuk penempatan alat pengambilan sampel hendaknya mengindari tempat-tempat yang secara kimiawi dapat merubah polutan yang akan diukur dan lokasi dengan arah angin dominan sepanjang jalan yang tidak akan membawa polutan masuk ke dalam probe. Ilustrasi sebagai arahan dalam

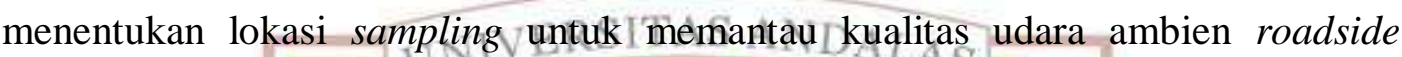
dapat dilihat pada Gambar 2.3

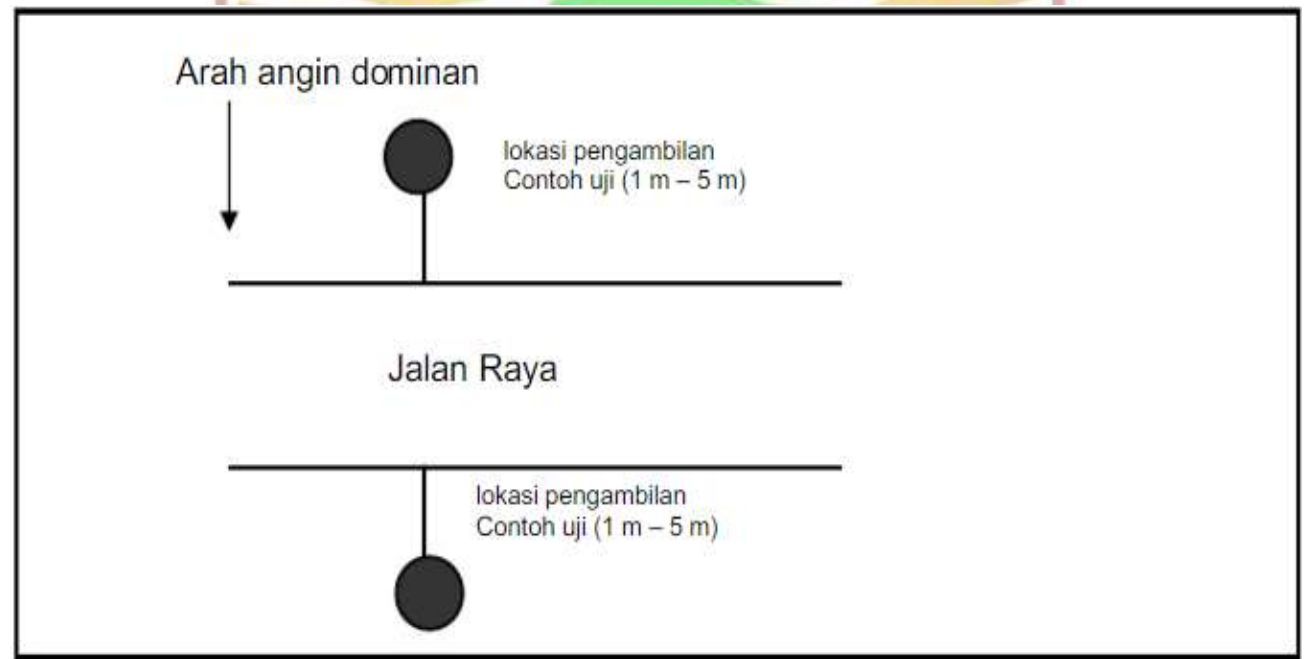

Gambar 2.3 Acuan Penentuan Lokasi Pemantauan Kualitas Udara Roadside Sumber: SNI 19-7119.9-2005

\subsection{Pohon Lindung sebagai Reduksi Polutan}

Pohon merupakan salah satu unsur yang penting bagi kehidupan, terutama kehidupan bagi manusia. Karena pohon mempunyai banyak manfaat seperti sebagai penghasil oksigen, pencegah banjir dan longsor, mereduksi pencemaran udara, sebagai penyimpan air hujan dalam area perakaran dan dapat mengurangi pemanasan global. Penanaman pohon sebagai peneduh jalan tidak boleh dilakukan sembarangan, harus ada kriteria tersendiri mengenai jenis pohon yang akan dijadikan sebagai pohon peneduh. Beberapa kriteria yang perlu diperhatikan antara lain adalah (Noviady dan Reza, 2015) dapat menyerap gas polutan lebih banyak dibanding jenis pohon lainnya, dapat menghasilkan oksigen lebih besar, tinggi 
pohon lebih dari 3 meter, namun tidak lebih dari 12 meter, rimbun dengan kerapatan daun yang bisa menutupi penetrasi sinar matahari, tajuk luas atau mampu menutupi area yang luas, perawatannya mudah, pertumbuhan tergolong cepat, daunnya tidak mudah rontok, ranting dan dahannya tidak mudah patah bila tertiup angin kencang, ranting atau cabang tidak berukuran terlalu besar, akar kuat menghujam ke dalam tanah sehingga pohon tidak mudah tumbang bila tertiup angin kencang, akar tidak timbul ke permukaan yang dapat merusak lantai dan tembok rumah atau trotoar, serbuk sarinya tidak bersifat alergi bagi penderita asma, dan disukai burung-burung.

Menurut Wardhana (2011) karakter umum tanaman yang mempunyai kemampuan tinggi menyerap polutan secara umum serupa. Tanaman memiliki tajuk rimbun, tidak mudah gugur daunnya, tanamannya relatif tinggi. Karakter khusus tanaman yang mempunyai kemampuan tinggi mengurangi polutan partikel memiliki ciri daun, memiliki bulu halus, permukaan daun kasar, daun bersisik, tepi daun bergerigi, daun berbentuk jarum, daun yang permukaannya bersifat lengket, efektif untuk menyerap polutan.

Menurut Santoso (2012) menyebutkan bahwa epidermis adalah target utama dari polutan udara, dimana polutan pertama masuk melalui stomata dan bereaksi dalam lubang ini melalui lubang-lubang ini, polutan terlarut dalam air permukaan sel-sel daun dan mempunyai $\mathrm{pH}$ sel. Selanjutnya bereaksi dengan sel mesofil. Setiap tanaman mempunyai karakteristik yang berbeda dalam mengabsorbsi gas-gas tertentu di udara, sehingga dapat merupakan penyangga yang baik terhadap pencemaran udara. Fungsi tanaman sebagai peneduh adalah hal yanng dipertimbangkan ketika memilih jenis tanaman yang digunakan untuk penghijauan. Hal ini disebabkan karena tanaman hijau dapat memulihkan iklim mikro dan menahan diseminasi dari polusi udara yang berasal dari kendaraan.

Cara meningkatkan kuallitas udara yang paling efektif adalah dengan vegetasi yang tersedia langsung dari alam. Maka seharusnya perlu dilakukan reboisasi atau menanam tumbuhan dengan segera agar kualitas udara tidak semakin menurun. Terdapat reaksi fotosintesi dari tumbuhan yang mana gas $\mathrm{CO}_{2}$ akan diubah menjadi 
$\mathrm{O}_{2}$ melalui proses tersebut. Tanaman peneduh jalan didefinisikan sebagai tanaman yang digunakan sebagai penghijauan. (Anatari dan Sundra, 2002).

Tanaman memiliki kapasitas dalam penjerapan dan mengakumulasi zat pencemar. Daun dari tanaman bisa menangkap partikel timbal yang berasa dari kendaraan bermotor (Hendrasari, 2007). Menurut Karliansyah (1999) penggunaan tanaman sebagai bioindikator merupakan salah satu cara untuk memantau kualitas udara. Keefektivan tiap tanaman guna penyesuaian diri berbeda-beda yang mengakibatkan perbedaan tingkat kepekaan, diantaranya cukup peka, kurang peka dan sangat peka. Perbedaan kepekaan tanaman memiliki hubungan terhadap keefektivan tanaman dalam menyerap dan mengumpulkan polutan. Oeh sebab itu tanaman merupakan bio indikator pencemaran yang baik.

Pengurangan dari meningkatnya pencemaran yang disebabkan oleh kendaraan bermotor ialah dengan adanya pohon pinggir jalan yang dapat menyerap maupun menjerap polutan berupa gas maupun partikulat hasil dari kendaraan bermotor. Pohon pelindung juga didefinisikan sebagai paru-paru dari perkotaan. Karakteristik pohon pinggir jalan yang dapat menjerap polutan di udara adalah yang memiliki daun lebar. Sel-sel daun berguna untuk menangkap $\mathrm{CO}_{2}$ maupun polutan lainnya dan dapat diolah oleh tanaman melalui proses fotosisntesi tanaman itu sendiri. Proses dari fotosintesis ini sendiri adalah dengan mengeluarkan oksigen dari stomata kemudian memasukan karbon dioksida $\left(\mathrm{CO}_{2}\right)$ ke dalam tanaman itu sendiri, sebagaimana oksigen merupakan gas yang dibutuhkan manusia untuk bernafas dengan baik, Beberapa jenis tanaman lain memiliki keefektivan dalam menyerap polutan, salah satunya adalah tanaman hias. Tanaman hias seperti bugenvil dan puring cukup disarankan untuk ditanam di perkotaan karena memiliki toleransi tinggi terhadap polutan (Nugrahani dan Sukartiningrum 2008).

Suasana jalan yang ditanami pohon akan menjadi lebih sejuk dan tidak silau. Menurut Dahlan, (2004) beberapa persyaratan penting dalam pemilihan jenis pohon pelindung jalan diantaranya adalah faktor keamanan bagi pemakai jalan. Tajuk pohon memberikan naungan yang sempurna tapi tidak terlalu teduh, agar tidak mengganggu lalu lintas. Tanaman yang tumbuh di tepi jalan harus tergolong dalam jenis tanaman yang mempunyai batang dan percabangan kuat, tidak mudah patah 
serta memiliki kelenturan yang cukup, sehingga pada saat tertiup angin yang kuat, tanaman tidak patah jatuh menimpa pemakai jalan. Tanaman juga tidak mudah roboh, karena memiliki perakaran yang kuat serta akarnya menghujam masuk ke dalam tanah, tidak menyebar di atas permukaan tanah saja. Tanaman pelindung antara lain sebagai paru-paru kota karena tumbuhan itu menghasilkan gas oksigen yang dibutuhkan oleh semua makhluk hidup, sebagai penyerap gas/partikel beracun untuk mengurangi pencemaran udara, sebagai peredam kebisingan dan sebagai habitat burung.

\subsubsection{Jenis - Jenis Pohon Lindung yang Mampu Menyerap Polutan}

Ada beberapa tanaman atau tumbuhan yang mempunyai kemampuan sebagai media penyerap polutan atau mengurangi pencemaran udara yang dihasilkan oleh industri dan alat transportasi. Tanaman yang mampu menyerap polutan dapat dilihat pada Tabel 2.2 :

Tabel 2.2 Jenis Pohon Lindung Penyerap Polutan

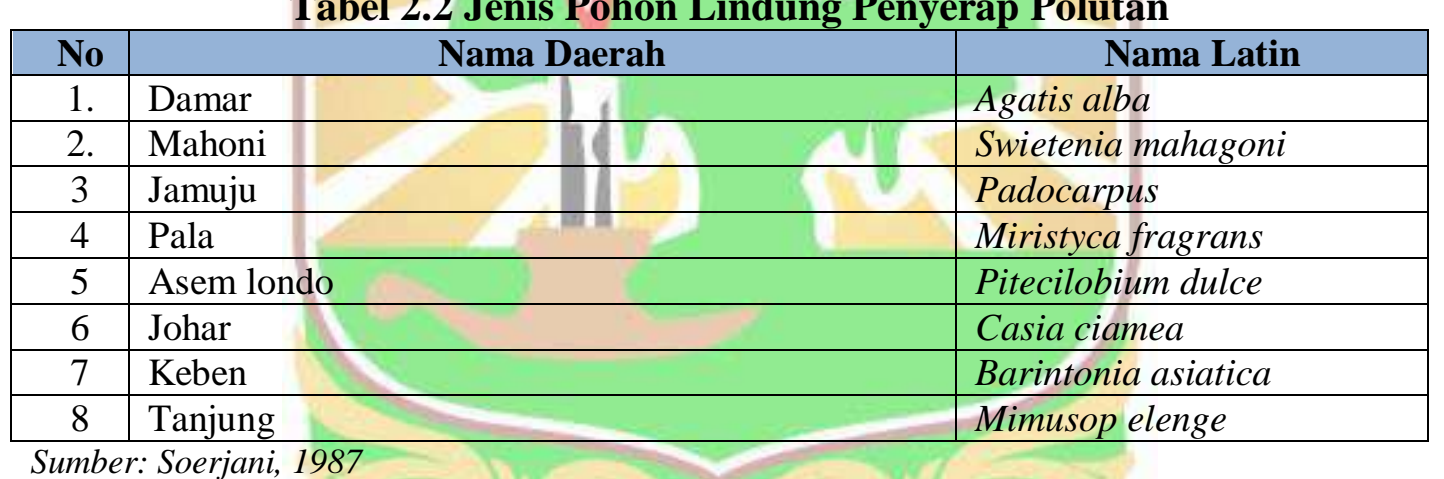

Beberapa jenis pohon lindung dari tabel di atas, terdapat beberapa pohon seperti pohon Angsana (Pterocarpus indicus), Kenari (Canarium indicum), Tanjung (Mimusops elengi) dan Mahoni (Swietenia macrophylla) yang merupakan jenis pohon pelindung jalan yang umum ditanam di beberapa kota di Indonesia. Hal ini selain bibitnya mudah didapat, keempat jenis tersebut memiliki perawakan tinggi dan rindang. Tidak semua pohon besar dan berpenampilan bagus dapat dijadikan sebagai pohon pelindung jalan. Ada beberapa persyaratan yang harus dipenuhi agar benar-benar berfungsi dengan baik dan tidak menambah permasalahan lain yang tidak diinginkan (Mansur, 2014). 


\section{Pohon Tanjung}

Menurut Hendrasarie (2007) Nama latin : Mimusop Elengi. Di Indonesia disebut Tanjung. Tanaman ini termasuk famili Sapotacea yang sudah banyak ditanam di pekarangan-pekarangan rumah, halaman perkantoran, dan di pinggir-pinggir jalan sebagai tanaman peneduh. Keistimewaan dari tanaman ini adalah bentuk tajuknya yang indah, perpaduan bentuk dan warna daunnya yang hijau mengkilat dan buahnya yang masak berwarna merah atau merah jingga sehingga jenis tanaman ini sangat bagus untuk komponen taman sekaligus untuk tanaman peneduh. Pohon tanjung termasuk jenis tanaman pohon yang bergetah, ketinggiannya dapat mencapai $15 \mathrm{~m}$, daun tunggal bertangkäi.ADuduk daun tersebar, bertepi rata, bertulang menyirip. Helaian daun berbentuk bulat memanjang atau bulat telur memanjanag, panjang 9-16 cm. Daun-daun yang muda berwarna coklat, bila sudah tua hijau. Tanjung dapat hidup dengan baik di tempat-tempat yang terbuka dan kena sinar matahari langsung, baik di dataran rendah maupun dataran tinggi, yakni pada ketinggian $1000 \mathrm{~m}$ di atas permukaan laut. Untuk mendapatkan tanaman yang sehat, media tanam atau lahan yang akan ditanami harus subur, gembur dan drainase diatur dengan baik.

\section{Pohon Mahoni}

Pohon Mahoni di Indonesia memiliki nama latin Swietenia Mahagoni. Nama asing dari tanaman ini adalah West Indian Mahogany. Tanaman ini termasuk famili Meliaceae, berasal dari benua Amerika yang beriklim tropis, tetapi sudah lama dibudidayakan di Indonesia, dan sudah beradaptasi dengan iklim tropis Indonesia. Tanaman mahoni banyak ditanam di pinggir-pinggir jalan atau di lingkungan rumah tinggal dan halaman perkantoran sebagai tanaman peneduh. Mahoni ditanam lebih banyak dibandingkan pohon lainnya. Kadang-kadang tanaman ini tumbuh secara liar di hutan-hutan datau diantara semak-semak belukar. Hal menarik dari tanaman ini adalah buahnya yang terlihat muncul di ujung-ujung ranting berwarna coklat (Hendrasarie, 2007).

Tanaman mahoni termasuk jenis tanaman pohon tinggi, percabangannya banyak, tingginya dapat mencapai kira-kira $10-30 \mathrm{~m}$. Mahoni dapat tumbuh dengan baik di tempat-tempat yang terbuka dan kena sinar matahari langsung, baik di dataran 
rendah maupun dataran tinggi, yakni hingga ketinggian $1000 \mathrm{~m}$ di atas permukaan laut. Untuk mendapatkan tanaman yang tumbuh baik dan sehat, media tanam atau lahan yang akan ditanami harus subur, gembur dan drainase diatur dengan baik, meski di tanah kritis pun tidak jadi masalah (Hendrasarie, 2007).

\subsubsection{Mekanisme Penyerapan Polutan oleh Tumbuhan}

Menurut Siringiringo (2000) kemampuan tanaman dalam menjerap timbal sangat dipengaruhi keadaan permukaan daun tanaman. Daun yang mempunyai bulu atau daun yang permukaannya kesat (berkerut) mempunyai kemampuan yang lebih tinggi dalam menjerap timbal, daripada daun yang mempunyai permukaan lebih licin dan rata. Kemampuan daun tanaman menjerap suatu polutan dipengaruhi oleh karakteristik morfologi daun, seperti ukuran dan bentuk daun, adanya rambut pada permukaan daun dan juga tekstur daun.

Menurut Nasrullah (2001), adanya tajuk pohon akan mengurangi jumlah polutan yang terlepas pada lingkungan melalui mekanisme difusi, absorpsi, adsorpsi, dan deposisi partikel. Difusi merupakan pemencaran polutan ke area yang lebih luas. Tajuk pohon yang tinggi dapat membelokkan hembusan angin ke atmosfir yang lebih luas. Absorpsi dan adsorpsi merupakan penyerapan polutan gas melalui stomata daun dan penjerapan partikel oleh permukaan daun, batang, dan ranting. Selain itu pemilihan pohon untuk meningkatkan kemampuan jalur hijau dalam menyerap polutan gas diharapkan sesuai dengan kriteria fisik pohon yang dapat menyerap polutan gas diantaranya memiliki tajuk yang rapat, jumlah daun yang banyak, dan daun yang tipis. Peningkatan penyerapan polutan gas juga dapat dilakukan dengan menambah kombinasi antara semak, perdu, dan tanaman penutup tanah pada tiap pohon. Kombinasi pohon dengan tanaman semak, perdu, dan tanaman penutup tanah akan meningkatkan penyaringan terhadap polutan gas. beberapa tanaman semak, perdu, dan tanaman penutup tanah juga memiliki kemampuan menyerap polutan gas dengan baik. Hanafri (2011) menyebutkan bahwa kriteria vegetasi yang berfungsi sebagai penyerap polutan, yaitu toleran terhadap polusi, kombinasi semak, penutup tanah, dan pohon dengan penataan berlapis-lapis, kerapatan tinggi, jarak tanam rapat, daun tebal dengan permukaan 
kasar, mempunyai trikoma dan kerapatan stomata tinggi, struktur tepi daun kasar/bergerigi/berbulu, batang dan cabang bertekstur kasar, evergreen.

Gas-gas di udara akan didifusikan ke dalam daun melalui stomata (mulut daun) pada proses fotosintesis atau terdeposisi oleh air hujan kemudian didifusikan oleh akar tanaman. Gas pencemar yang masuk ke jaringan daun melalui lubang stomata yang berada pada epidermis atas. Masing - masing stomata dapat membuka jika tekanan air internal berubah, yang merupakan lubang keluar masuknya pencemar udara. Walaupun secara umum terdapat kutin pada jaringan epidermis atas, gas pencemar dapat masuk ke jaringan daun melalui stomata. Epidermis ini adalah target utama dari pencemar udara, dimänaspencemar udara pertama masuk melalui stomata dan bereaksi melalui lubang - lubang ini, pencemar udara terlarut dalam air di permukaan sel - sel daun dan mempunyai $\mathrm{pH}$ sel. Selanjutnya bereaksi dengan sel mesofil. Setiap tanaman mempunyai karakteristik yang berbeda dalam mengabsorbsi gas-gas tertentu udara dan merupakan penyangga yang baik terhadap pencemaran udara. Beberapa tanaman mampu mengubah pencemar udara menjadi asam organik, gula dan beberapa senyawa asam amino (Siahaan, 2012).

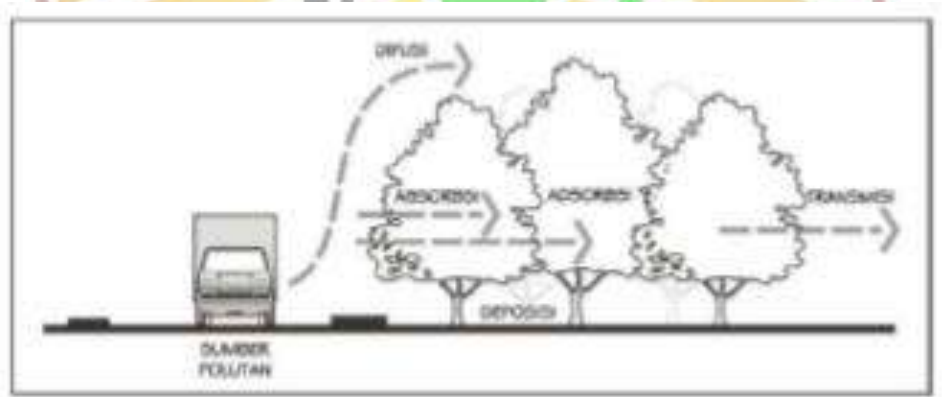

\section{Gambar 2.4 Mekanisme Tanaman dalam Menyerap Polusi}

(Sumber: Alhakim, 2014)

Yang, dkk (2005) menjelaskan bahwa pohon dapat mengurangi polutan dalam dua cara:

1) Dengan pengurangan langsung dari udara;

Pengurangan secara langsung, pohon dapat mengabsorpsi polutan gas seperti $\mathrm{SO}_{2}, \mathrm{NO}_{2}$ dan Ozon melalui stomata daun dan juga dapat melarutkan polutan dalam permukaan daun yang lembab; tajuk pohon juga dapat mengintersepsi partikulat udara.

2) Secara tidak langsung. 
Pohon dapat menurunkan suhu udara dengan naungan langsung dan evapotranspirasi, sehingga emisi polutan udara dari penggunaan mesin pendingin dapat dikurangi. Selain itu, penurunan suhu udara dapat mengurangi aktivitas reaksi kimia yang dapat menghasilkan polutan sekunder.

\subsubsection{Identifikasi Pohon Pelindung dalam Menyerap Gas Polutan}

Identifikasi pohon pelindung sangat penting dilakukan supaya dapat diketahui pohon pelindung menyerap polutan gas di suatu daerah dengan baik. Mengidentifikasi karakteristik jalur hijau di jalan dilakukan dengan metode deskriptif dan pengamatan langsung di jalur tersebut dengan cara visual. Dilakukan pengambilan gambar melalui kamera maupun google maps untuk mengidentifikasi bagaimana karakter pohon pelindung.

Tabel 2.3 Kriteria Penilaian Ekologis Pohon

\begin{tabular}{|c|c|}
\hline Aspek Fungsi Pohon & Kriteria Penilaian \\
\hline Penyerap Polutan Gas & $\begin{array}{l}\text { 1. Kepadatan tajuk (Carpenter dkk, 1975) } \\
\text { 2. Daun tipis (Patra,2002) } \\
\text { 3. Jumlah daun banyak (Fakuara, 1986) } \\
\text { 4. Jarak tanam rapat (Fakuara, 1986) }\end{array}$ \\
\hline
\end{tabular}

Dilakukan penilaian atau skoring pada setiap jenis pohon. Kemudian diberikan nilai antara 1 hingga 4 terhadap masing-masing kriteria berdasarkan sesuai atau tidaknya ciri fisik dan kondisi lapang pohon dengan kriteria yang telah ditentukan dimana :

1. Nilai 1 berarti tidak sesuai; D JA JA A N

2. 2 berarti kurang sesuai;

3. nilai 3 berarti sesuai;

4. dan 4 berarti sangat sesuai dengan kriteria penilaian.

Nilai tertinggi atau bisa juga disebut nilai maksimal pada setiap kriteria adalah nilai 4. Nilai yang didapat dari tiap kriteria kemudian dilakukan penjumlahan lalu dibandingkan terhadap jumlah ideal atau nilai maksimum dari tiap kriteria penilaian. Hasil dari perbandingan lalu diubah ke dalam bentuk persentase untuk didapatkannya persentase nilai evaluasi. Dari hasil tersebut didapatkan hasil penilaian dalam bentuk persen. 
Nilai Evaluasi $=\frac{\text { Jumlah total kriteria penilaian }}{\text { jumlah total nilai ideal kriteria penilaian }} \times 100 \%$

Hasil penilaian tersebut kemudian dikelompokkan dalam empat kategori penilaian yaitu sangat sesuai, sesuai, kurang sesuai, tidak sesuai. Pengelompokkan hasil penilaian menggunakan 5 selang dimana nilai bobot sempurna yaitu $100 \%$ dibagi menjadi 5 selang sama besar, sebesar $20 \%$ yaitu:

1. Nilai $100 \%-81 \%$ merupakan kategori sangat sesuai,

2. $81 \%-61 \%$ merupakan kategori sesuai,

3. $60 \%-41 \%$ merupakan kategori kurang sesuai, dan

4. nilai $40 \%$ atau kurang dari itu termasuk kedalam kategori tidak sesuai.

Untuk penelitian ini, selang $40 \%$ terendah dikelompokkan dalam satu kategori tidak sesuai. Pembobotan $40 \%$ terendah untuk kategori tidak sesuai ditujukan untuk meningkatkan standar penilaian (Hidayat, 2008). Pengelompokan persentase pembobotan aspek fungsi jalur hijau jalan dapat dilihat pada Tabel berikut:

Tabel 2.4 Pengelompokan Persentase Pembobotan Fungsi Ekologis Pohon

\begin{tabular}{|c|l|l|}
\hline No & \multicolumn{1}{|c|}{ Kesesuaian } & \multicolumn{1}{c|}{ Nilai } \\
\hline 1. & Buruk & $<40 \%$ kriteria terpenuhi \\
\hline 2. & Kurang sesuai & $41-60 \%$ kriteria terpenuhi \\
\hline 3. & Sesuai & $61-80 \%$ kriteria terpenuhi \\
\hline 4. & Sangat sesuai & $>80 \%$ kriteria terpenuhi \\
\hline
\end{tabular}

Setelah dilakukan penilaian terhadap pohon jalur hijau jalan, didapatkan nilai kuantitatif dan kualitatif dari vegetasi jalan untuk fungsi ekologis yang diteliti serta pengelompokkannya seperti telah disebutkan sebelumnya. Hasil penilaian kemudian diolah menjadi data spasial untuk menggambarkan sebaran vegetasi.

\subsection{Penelitian Terkait}

\subsubsection{Pengaruh Kepadatan Kendaraan Bermotor terhadap Konsentrasi CO} Ambien (Studi Kasus Jalan Taman Siswa Yogyakarta) (Putra, 2012)

Tujuan dari penelitian ini adalah untuk mengetahui besarnya konsentrasi CO di Jalan Taman Siswa, tujuan selanjutnya adalah mengetahui pangaruh kepadatan kendaraan bermotor pada konsentrasi karbon monoksida, kemduain yang terakhir mengetahui pengaruh faktor meteorologis (suhu, kelembapan, kecepatan angin) terhadap konsentrasi karbon monoksida. Penelitian ini menggunakan metode 
moving observation techniqu dalam melakukan pengambilan data. Kemudian untun menentukan lokasi sampling digunakan metode purposive sampling.

Hasil dari penelitian ini adalah nilai konsentrasi karbon monoksida tertinggi 33 ppm sedangkan yang terkecil sebesar 14 ppm. Konsentrasi karbon monoksida masih di bawah baku mutu udara ambien DIY. Variabel yang berpengaruh paling besar terhadap kenaikan atau penurunan konsentrasi karbon monoksida adalah kepadatan kendaraan bermotor. Penelitian ini menghasilkan konsentrasi karbon monoksida yang dapat dilihat pada persamaan regresi $=4,414+0,137$ (kelembapan udara) + 0,002 (kepadatan kendaraan bermotor)

\subsubsection{Tingkat Pencemaran Udara CO akibat Lalu Lintas dengan Model} Prediksi Polusi Udara Skala Mikro (Sengkey dkk, 2011)

Penelitian ini bertujuan untuk mengetahui besarnya konsentrasi CO yang dikeluarkan oleh lalu lintas kendaraan bermotor khususnya di ruas jalan Sam Ratulangi Manado. Metode yang digunakan dalam penelitian ini yaitu melalui survei dan observasi lapangan. Penelitian ini menggunakan analisis data berupa pemodelan polusi udara skala mikro. Persentase CO ditentukan dengan berapa nilai CO yang timbul oleh lalu lintas yaitu dengan cara membandingkan hasil perhitungan pemodelan dengan hasil pengukuran udara ambient. Hasil dari penelitian ini adalah konsentrasi gas $\mathrm{CO}$ akibat lalu lintas di ruas jalan Sam Ratulangi Manado berkisar 7.242,99 $\mu \mathrm{g} / \mathrm{m}^{3}$ hingga 15.577,07 $\mu \mathrm{g} / \mathrm{m}^{3}$. Dapat dilihat dari hasil penelitian ini bahwa nilai $\mathrm{CO}$ yang dihasilkan belum melampaui ambang batas baku mutu udara ambient nasional. Dari jumlah polutan CO yang ada di udara $80,22 \%$ - 92,00\% berasal dari kendaraan bermotor.

\subsubsection{Hubungan Kepadatan Lalu Lintas dengan Konsentrasi CoHb pada Masyarakat Berisiko Tinggi di Sepanjang Jalan Nasional Kota Semarang} (Anggarani dkk, 2015)

Pencemaran di daerah perkotaan disebabkan oleh besarnya transportasi jalan raya yang signifikan. Semakin tinggi tingkat polusi Karbon monoksida (CO) di udara disebabkan oleh kendaraan bermotor yang semakin ramai. Dampak terburuk dari gas $\mathrm{CO}$ adalah penurunan kapasitas darah untuk mengikat oksigen yang disebabkan oleh paparan gas CO dalam darah manusia. Penelitian Anggarani dkk (2016) ini 
bertujuan untuk mengetahui hubungan dan pengaruh kepadatan lalu lintas dengan konsentrasi $\mathrm{COHb}$ pada masyarakat berisiko tinggi di sepanjang jalan nasional Kota Semarang. Jenis penelitian yang digunakan adalah penelitian observasional dengan pendekatan cross sectional. Populasi dalam penelitian ini adalah 20 titik jalan nasional dan warga yang melakukan aktivitas di sepanjang jalan nasional. Sampel dari penelitian ini adalah ruas jalan kelima dengan jumlah responden sebanyak 29 orang dengan menggunakan teknik quota sampling.

Hasil penelitian dengan uji rank spearman menunjukkan bahwa terdapat hubungan kepadatan lalu lintas dengan konsentrasi $\mathrm{COHb}$ pada masyarakat berisiko tinggi di ruas jalan nasional Semarang dengan $\left(p \neq 0,0001, r_{A}=0,629\right)$ dan dengan uji regresi linier tidak ditemukan pengaruh kemacetan lalu lintas $(p=0,0001)$, kadar air $(p=$ $0,04)$ dan usia $(\mathrm{p}=0,009)$ dengan konsentrasi $\mathrm{COHb}$ di komunitas berisiko tinggi. Kesimpulan dari penelitian ini adalah ada hubungan dan pengaruh kepadatan lalu lintas dengan konsentrasi $\mathrm{COHb}$ pada masyarakat berisiko tinggi. Saran dalam penelitian ini sebaiknya pemeriksaan rutin kadar CO udara di Kota Semarang dan penataan kembali kawasan niaga yang ramah lingkungan.

\subsubsection{Perbandingan Kadar $\mathrm{CO}$ dan Nitrogen Dioksida $\left(\mathrm{NO}_{2}\right)$ di Udara Ambien Berdasarkan Keberadaan Pohon Angsana (Pterocarpus indicus) di beberapa Jalan Raya Di Kota Medan Tahun 2012 (Yulfida dkk, 2012)}

Penelitian ini bertujuan untuk mengetahui perbandingan kadar $\mathrm{CO}$ dan nitrogen dioksida $\left(\mathrm{NO}_{2}\right)$ di udara ambien pada jalan raya berdasarkan keberadaan pohon Angsana (Pterocarpus indicus) di beberapa jalan raya di kota. Metode pemeriksaan sampel CO dilakukan dengan menggunakan alat CO Analyzer dan sampel nitrogen dioksida $\left(\mathrm{NO}_{2}\right)$ dilakukan dengan menggunakan alat Impinger.Metode pemeriksaan sampel $\mathrm{CO}$ dilakukan dengan menggunakan alat $\mathrm{CO}$ Analyzer dan sampel nitrogen dioksida $\left(\mathrm{NO}_{2}\right)$ dilakukan dengan menggunakan alat Impinger. Hasil dari penelitian ini adalah kadar Nitrogen dioksida $\left(\mathrm{NO}_{2}\right)$ dan Karbon dioksida yang terdapat pada jalan raya yang ditanami pohon Angsana (Pterocarpus indicus) lebih rendah dibandingkan pada jalan raya yang tidak ditanami pohon Angsana (Pterocarpus indicus). 
Tabel 2.5 Hasil Penelitian Kadar Karbon monoksida (CO) dan Nitrogen Dioksida $\left(\mathrm{NO}_{2}\right)$ Pada Jalan Raya yang Ditanami dan yang Tidak Ditanami

Pohon Angsana (Pterocarpus indicus) di Kota Medan Tahun 2012

\begin{tabular}{|c|c|c|c|c|c|c|}
\hline \multirow{3}{*}{ No } & \multirow{3}{*}{ Parameter } & \multirow{3}{*}{$\underset{\left(\mu \mathrm{g} / \mathbf{N m}^{3}\right)}{\mathbf{N A B}}$} & \multicolumn{4}{|c|}{ Titik Penelitian } \\
\hline & & & \multicolumn{2}{|c|}{$\begin{array}{c}\text { Jalan Raya yang } \\
\text { Ditanami Pohon } \\
\text { Angsana } \\
\end{array}$} & \multicolumn{2}{|c|}{$\begin{array}{l}\text { Jalan Raya yang } \\
\text { tidak Ditanami } \\
\text { Pohon Angsana }\end{array}$} \\
\hline & & & 1 & 2 & 3 & 4 \\
\hline 1 & $\mathrm{CO}$ & 30.000 & 16.033 & 4.581 & 12.597 & 16.033 \\
\hline 2 & $\mathrm{NO}_{2}$ & 400 & 9,22 & 10,39 & 29,78 & 10,37 \\
\hline
\end{tabular}

Sumber : Yulfida dkk, 2012

\subsubsection{Kandungan Timbal (Pb) pada Tanaman Peneduh di Jalan Tuanku}

Tambusai Kota Pekanbaru (Ningrum dkk, 2016)

Tujuan dari penelitian ini adalah untuk mengetahui jumlah kandungan timbal pada tanaman peneduh di jalan Tuanku Tambusai Kota Pekanbaru serta mengetahui jenis tanaman peneduh dan strata tajuk yang paling banyak menyerap timbal pada tanaman peneduh di jalan Tuanku Tambusai kota Pekanbaru. Penelitian ini dilakukan dengan pengambilan sampel daun glodokan, mahoni dan angsana sehingga dihasilkan kadar timbal yang berbeda - beda untuk setiap sampel daun. Kandungan $\mathrm{Pb}$ pada daun dapat dilihat pada Tabel berikut ini

Tabel 2.6 Kandungan Timbal antara Daun Glodokan, Angsana dan Mahoni

\begin{tabular}{|c|l|c|}
\hline No & Jenis Tanaman & Kandungan Timbal pada Daun $(\mu \mathrm{g} / \mathrm{g})$ \\
\hline 1 & Glodokan & 1,88 \\
\hline 2 & Angsana & 1,57 \\
\hline 3 & Mahoni & 1,16 \\
\hline
\end{tabular}

Hasil penelitian memperlihatkan bahwa ada perbedaan kandungan timbal pada daun masing-masing pohon dengan jenis yang sama yaitu glodokan. Hasil pengukuran kandungan logam timbal pada sampel daun glodokan menggunakan spektrofotometer serapan atom. Jumlah kandungan timbal pada daun glodokan yaitu $1,88 \mu \mathrm{g} / \mathrm{g}$, angsana (Pterocarpus indicus Willd) 1,57 $\mu \mathrm{g} / \mathrm{g}$ dan mahoni (Swietenia macrophylla) 1,16 $\mu \mathrm{g} / \mathrm{g}$. Kandungan timbal pada tanaman peneduh di jalan Tuanku Tambusai Kota Pekanbaru berkisar antara 1,16-1,88 $\mu \mathrm{g} / \mathrm{g}$ dan tergolong berada pada kadar sedang/normal timbal pada tanaman yaitu 0,5-3,0 $\mu \mathrm{g} / \mathrm{g}$. 2. Kandungan timbal pada daun glodokan lebih tinggi dibandingkan dengan kandungan timbal pada daun angsana dan daun mahoni. Kandungan timbal pada 
strata tajuk bagian tengah $(1,72 \mu \mathrm{g} / \mathrm{g})$ lebih tinggi dibandingkan kandungan timbal pada strata tajuk bagian bawah $(1,52 \mu \mathrm{g} / \mathrm{g})$ dan strata tajuk bagian atas $(1,38 \mu \mathrm{g} / \mathrm{g})$.

\subsubsection{Kajian Efektivitas Tanaman dalam Menjerap Kandungan Pb di Udara} (Hendrasarie, 2007)

Penelitian ini bertujuan mengevaluasi efektivitas tanaman (pohon Tanjung dan Mahoni) dalam menjerap logam berat $(\mathrm{Pb})$ di udara. Adapun manfaat dari penelitian ini antara lain : Dapat mengurangi pencemaran $\mathrm{Pb}$ yang dihasilkan oleh kendaraan bermotor dan menjadi salah satu alternatf dalam mengurangi polusi udara. Pohon pelindung yang diuji pada penelitian ini adalah pohon tanjung dan pohon mahoni. Hasil dari penelitian ini menunjukan bahwa penyerapan polutan $\mathrm{Pb}$ oleh beberapa pohon pelindung sangat efektif. Kandungan $\mathrm{Pb}$ terbesar ada pada daun Mahoni. Ini berarti bahwa kemampuan daun Mahoni dalam mejerap $\mathrm{Pb}$ lebih baik daripada daun Tanjung. Adanya perbedaan pada penjerapan daun Mahoni dan Tanjung ini disebabkan karena luas daun antara daun Mahoni dan Tanjung berbeda. Luas daun Mahoni lebih besar daripada luas daun Tanjung. Selain itu juga dipengaruhi oleh permukaan daunnya. Daun Mahoni lebih banyak menyerap $\mathrm{Pb}$ karena daunnya kasat atau berbulu halus (pubescens) dan rapat, sedangkan daun Tanjung menjerap $\mathrm{Pb}$ lebih sedikit karena daunnya licin dan gundul (glabrous). Rendahnya kandungan $\mathrm{Pb}$ dalam daun yang permukaannya licin, disebabkan karena lebih mudah tercuci air hujan atau disapu oleh angin. Kemudian untuk kandungan logam berat $\mathrm{Pb}$ yang terbesar ada pada batang Tanjung. Selisih persentase penyerapan pada 2 minggu pertama antara batang Tanjung I dan batang Mahoni I sebesar 1,10 \%, batang Tanjung II dan batang Mahoni II sebesar 7,95 \%, batang Tanjung III dan batang Mahoni III sebesar 4,14\%. Dan selisih persentase penyerapan pada 2 minggu kedua antara batang Tanjung I batang Mahoni I sebesar 0,95\%, batang Tanjung II - batang Tanjung II sebesar 4,92 \%, batang Tanjung III - batang Mahoni III sebesar 2,79 \%. Ini berarti bahwa kemampuan batang Tanjung memiliki kemampuan menjerap $\mathrm{Pb}$ lebih baik dari pada batang mahoni. Batang Tanjung lebih banyak kandungan $\mathrm{Pb}$ nya karena batang tanjung permukaan batangnya lebih kasar dari pada batang mahoni. Selain itu batang tanjung tekstur batangnya lebih kasar daripada batang Mahoni. Dari hasil penelitian yang dilakukan maka didapat hasil presentase penyerapan keseluruhan, yaitu : 
1. Tanjung I (Pagi) : 37,18 \%

2. Tanjung II (Siang) : 69,28\%

3. Tanjung III (Sore) $: 88,25 \%$

4. Mahoni I (Pagi) : 43,31\%

5. Mahoni II (Siang) : 63,37\%

6. Mahoni III (Sore) : 83,09\%

\subsubsection{Peranan Tanaman terhadap Pencemaran Udara di Jalan Protokol Kota}

\section{Semarang (Martuti, 2007)}

Tujuan penelitian ini adalah mengetahui peranan tanaman di jalan-jalan protokol Kota Semarang dilihat dari kualitas dản kuântitasnya. Data mengenai jenis tanaman peneduh yang ada di jalan protokol Kota Semarang dihitung dengan metode line intercept. Populasi dalam penelitian ini adalah tanaman peneduh yang ada di jalan protokol Kota Semarang. Penetapan stasiun pengambilan sampel didasarkan kepada kepadatan populasi kendaraan.

Keragaman dan jumlah jenis tanaman di masing-masing stasiun 1 ternyata tidak berpengaruh positif terhadap kadar bahan pencemar di lokasi tersebut. Hal ini dimungkinkan karena jenis tanaman yang ada tidak seimbang serta tidak sesuai dengan kadar bahan pencemar yang ada, terutama kadar CO. Tanaman angsana yang mendominasi di wilayah Kalibanteng atau ruas jalan lainnya ternyata mempunyai kemampuan kecil dalam menyerap $\mathrm{CO}_{2}(11,12 \mathrm{~kg} /$ pohon/ tahun). Tetapi adanya angsana ini dimungkinkan mampu sebagai penjerap yang baik untuk $\mathrm{Pb}$, dikarenakan $\mathrm{Pb}$ pada lokasi penelitian sangat kecil $(0,021-0,054)$ jauh di bawah baku mutu yang ditentukan.

Hasil penelitian tersebut dapat diketahui bahwa jenis maupun jumlah tanaman yang ada pada masing-masing setasiun penelitian tidak berpengaruh positif terhadap kadar bahan pencemar udara yang ada. Hal ini dikarenakan jenis dan jumlah tanaman pada masing-masing jalan protokol tidak sesuai dengan tanaman peneduh yang mempunyai fungsi sebagai penjerap polutan udara. Untuk itu perlu kiranya adanya penataan kembali terhadap jenis-jenis tanaman peneduh yang ditanam di ruas jalan-jalan protokol Semarang. Sehingga fungsi tanaman sebagai peneduh dan penjerap bahan-bahan pencemar benar-benar dapat maksimal seperti 
yang diharapkan. Hasil tersebut perlu kiranya mengupayakan pengurangan atau meminimalis kandungan bahan pencemar udara yang ada di jalan-jalan protokol Kota Semarang. Salah satu solusi yang dapat dilakukan adalah dengan melakukan penghijauan di ruas-ruas jalan protokol tersebut

\subsubsection{Pengaruh Penghijauan Dalam Mereduksi CO pada Daerah Traffic Light}

\section{Di Kota Pontianak (Tiffani dkk, 2015)}

Penelitian ini bertujuan untuk menganalisis pengaruh keberadaan pohon dalam mereduksi CO pada daerah traffic light di Kota Pontianak. Desain penelitian dilakukan secara observasional dengan pendekatan Cross Sectional. Objek dalam penelitian ini adalah udara ambien yang berasal darildaerah traffic light pada jalan nasional Kota Pontianak. Adapun banyaknya pengambilan sampel di sesuaikan jumlah traffic light pada jalan nasional di Kota Pontianak. Penelitian Tiffani (2015) dilakukan pada daerah traffic light, hal ini dikarenakan gas buangan kendaraan paling tinggi ketika kendaraan berhenti.

Data pemeriksaan kadar CO pada daerah traffic light berjumlah 10 lokasi sampel penelitian yang di uji di Unit Pelayanan Hiperkes Pontianak dengan hasil tertinggi terdapat pada traffic light jalan Tanjung Pura (Hotel Garuda) dengan kadar CO yaitu $11.364,19 \mu \mathrm{g} / \mathrm{Nm}^{3}$ dan paling terendah terdapat pada jalan Pak Kasih yaitu 4.264,21 $\mu \mathrm{g} / \mathrm{Nm}^{3}$. Hasil Pengukuran kadar CO pada sepuluh lokasi. Dari penelitian di dapatkan bahwa 10 hasil sampel dari 10 lokasi yang berbeda menghasilkan nilai konsentrasi CO dibawah baku mutu dan dapat dikatakan aman.

Dari hasil yang didapat bahwa kadar karbon monoksida (CO) tertinggi didaerah jalan tanjung pura (Hotel Garuda) yaitu 11.364,19 $\mu \mathrm{g} / \mathrm{Nm}^{3}$ dengan jumlah Intensitas kendaraan 8.163 kendaraan dan jumlah pohon sebanyak 23 pohon Angsana jumlah pohon yang cukup banyak di daderah tersebut tetapi kadar karbon monoksida (CO) tinggi juga disebabkan oleh jenis pohon yang ditanam didaerah tersebut bukanlah jenis pohon yang berfungsi sebagai penyerap polutan. Seperti yang dijelaskan pada penelitian (Febri, 2011) bahwa pohon angsana untuk tujuan sebagai peneduh jalan dapat menggunakan pohon Angsana dikarenakan struktur pohon Angsana yang lebih rindang apabila dibandingkan dengan pohon Tanjung, 
tetapi bila dibedakan dari segi efektivitas penjerap polutan akan lebih baik ditanam pohon Tanjung.

Pada penelitian ini (Tiffani, 2015) dapat diketahui bagaimana pengaruh keberadaan pohon pelindung terhadap kadar CO. Peneliti melakukan analisis bivariat dengan uji korelasi. Hasil analisis bivariat antara keberadaan pohon dengan kadar CO pada daerah traffic light jalan Nasional kota Pontianak menunjukan bahwa $r=0,067$ (korelasi sangat lemah) dengan $\mathrm{p}$-value $=0,788>0,05$ Ho diterima, jadi tidak ada pengaruh antara keberadaan pohon dengan kadar CO di traffic light kota Pontianak.

Tidak adanya pengaruh antara keberadaan pohon dengan kadar CO dapat dijelaskan bahwa dari hasil observasi dilapangan.LHasil observasi keberadaan pohon pelindung menunjukkan rata-rata jarak pohon cukup dekat dengan daerah traffic light, tetapi jarak antara satu pohon dengan pohon yang lain berbeda beda sehingga penyerapan kadar karbon di udara tidak terjadi dengan maksimal (Tiffani, 2015). Terdapat daerah yang memiliki keberadaan pohon dekat tetapi kadar CO tinggi dan juga terdapat wilayah yang memiliki keadaan kadar $\mathrm{CO}$ rendah tetapi keberadaan pohon jauh. Keadaan tersebut menunjukkan bahwa pohon yang berada di traffic light belum berfungsi cukup baik sebagai penyerap CO. Kemudian hasil observasi di lapangan juga terdapat jenis pohon yang kurang mampu menyerap polutan yaitu pohon pohon yang dipilih untuk keindahan tata kota.

\subsubsection{Penelitian tentang "Efektivitas Jalur Hijau Jalan dalam Mengurangi} Polutan Gas CO" (Izzah dkk, 2019)

Tujuan penelitian ini adalah untuk memberikan gambaran tentang pengaruh area vegetasi dan area terbuka dalam mengurangi penyebaran polutan gas $\mathrm{CO}$ yang dihasilkan oleh kegiatan transportasi. Penelitian ini dilakukan di jalur hijau jalan Tol Cikampek. Pengambilan sampel udara dilakukan untuk mengukur konsentrasi CO dalam jarak 0, 10, dan $30 \mathrm{~m}$ dari tepi jalan jalur hijau. Untuk menentukan konsentrasi CO digunakan analisis dengan metode spektofotometri. Pengurangan konsentrasi gas $\mathrm{CO}$ oleh masing-masing pengukuran diperoleh dengan membandingkan kualitas udara dari hasil pengukuran pada jalur hijau area vegetasi dengan kualitas udara pada plot kontrol, yaitu area terbuka. Untuk mengetahui pengaruh jalur hijau pada pengurangan konsentrasi gas CO dilakukan penelitian 
menggunakan rancangan percobaan dengan dua faktor, yaitu keberadaan jalur hijau dan jarak dari jalan. Selanjutnya, data konsentrasi gas CO dan pengurangan gas CO oleh vegetasi diolah dengan uji ANOVA. Hasil penelitian menunjukkan bahwa konsentrasi gas $\mathrm{CO}$ pada plot vegetasi lebih sedikit dibandingkan dengan pada plot terbuka. Area vegetasi sangat efektif dalam mengurangi konsentrasi polutan gas CO. Vegetasi jalur hijau jalan dapat menurunkan sebaran kosentrasi CO secara efektif sebesar $8,5 \%$ dibandingkan dengan jalur terbuka.

\subsubsection{The Impact of Roadside Vegetation Barriers on the Dispersion of Gaseous} Traffic Polution in Urban Street Canyons (Li dkk, 2016)

Penelitian ini bertujuan untuk melihat bagaimana perbedaan konsentrasi $\mathrm{CO}$ berdasarkan keberadaan vegetasi pada beberapa jalan di Shanghai, Cina. Metode yang digunakan adalah numerical model 2 dimensi. Pengukuran CO dilakukan dengan alat electrochemical monitor. Hasil penelitian menunjukan bahwa konsentrasi CO tinggi pada daerah tanpa vegetasi sedangkan konsentasi CO lebih rendah pada jalan yang memiliki vegetasi. Hasil ini menunjukan bahwa terjadinya reduksi $\mathrm{CO}$ oleh vegetasi yang ada di pinggiran jalan.

Penelitan ini juga menjelaskan bahwa vegetasi memperbaiki kualitas udara terutama konsentrasi CO di jalan raya. Rata-rata konsentrasi CO berata di atas 0,16 ppm ketika nilai ketinggian vegetasi 0 , kemudian pengukuran pada vegetasi dengan ketinggian 0,5 m kadar CO berada di bawah angka 0,12 ppm. Selain itu konsentrasi CO menurun terhadap ketinggian vegetasi. Semakin tinggi vegetasi maka akan semakin rendah nilai konsentrasi $\mathrm{CO}$. Keefektivan vegetasi dalam mereduksi $\mathrm{CO}$ disebabkan oleh beberapa faktor, yaitu tinggi vegetasi dan kecepatan angin.

\subsubsection{The Effects of Vegetation Barriers on Near-Road Ultrafine Particle} Number and Carbon Monoxide Concentrations (Lin dkk, 2016)

Penelitian ini bertujuan untuk melihat pengaruh vegetasi terhadap konsentasi CO. Dilakukan pengukuran pada 2 jalan berbeda di daerah Chapel Hill dan Mebane. Rata-rata tinggi pohon pelindung di daerah Chapel Hill adalah 4-8 meter sedangkan tinggi pohon di Mebane berkisar dari 6 sampai 8 meter. Rata-rata luas vegetasi di Chapel hill juga lebih rendah dibanding Mebane. Chapel Hill memiliki luas vegetasi sekitar 2-5 m sedangkan luas vegetasi di Mebane mencapai 3-6 m. 
Besar kecilnya luas vegetasi disebabkan oleh banyak sedikitnya jumlah pohon dan banyak sedikitnya daun yang ada pada pohon pelindung. Konsentrasi CO menunjukkan penurunan rata-rata $23,6-56,1 \%$. Reduksi CO rata-rata lebih besar di Mebane dibanding Chapel Hill yang salah satu faktornya adalah tinggi pohon pelindung. Semakin tinggi pohon pelindung semakin besar tingkat reduksi yang terjadi.

\subsubsection{Carbon Sequestration by Urban Trees on Roadsides of Vadodara City} (Kiran dan Kiranny, 2011)

Peningkatan potensi efek rumah kaca bumi merupakan masalah lingkungan yang kritis. Karbon dioksida $\left(\mathrm{CO}_{2}\right)$ adalah penyumbang páling signifikan bagi pengaruh manusia terhadap efek rumah kaca. Karena emisi $\mathrm{CO}_{2}$ secara langsung terkait dengan banyak kegiatan ekonomi yang makmur, sulit bagi masyarakat untuk segera mencapai pengurangan besar dalam produksinya. Saat pohon tumbuh, mereka menghilangkan $\mathrm{CO}_{2}$ dari atmosfer selama proses fotosintesis. $\mathrm{CO}_{2}$ ditetapkan sebagai karbon organik yang terakumulasi dalam bentuk biomassa. Hasil penelitian menunjukkan bahwa 73,59 ton $\mathrm{CO}_{2}$ dihilangkan oleh pohon yang ditanam di sisi jalan kota Vadodara yang mewakili $22 \%$ dari perkiraan total produksi $\mathrm{CO}_{2}$ kota. Total emisi $\mathrm{CO}_{2}$ di jalan-jalan utama ditemukan sekitar 159,47 ton karena lebih banyak jumlah mobil karena ini adalah kota terpadat ketiga di negara bagian Gujarat, India. Hasilnya terbatas pada $\mathrm{CO}_{2}$ yang diserap oleh pohon yang ditanam hanya di sisi jalan tidak termasuk penyerap karbon lainnya. Oleh karena itu, jelas bahwa penanaman pohon di pinggir jalan merupakan metode yang efektif untuk mengimbangi $\mathrm{CO}_{2}$ dari sumber daya manusia.

\subsubsection{Analisis Pencemaran Udara Akibat Kepadatan Jalan Lalu Lintas Kota} Padang (Studi Kasus: CO di Jalan Prof Dr Hamka, Jl Khatib Sulaiman dan Jalan Rasuna Said) (Wijaya, 2018)

Penelitian ini bertujuan untuk: (1) mengetahui kepadatan kendaraan bermotor Jalan Prof. Dr. Hamka, Jalan Khatib Sulaiman, dan Jalan Rasuna Said, Kota Padang, (2) mengetahui volume karbon monoksida $(\mathrm{CO})$ yang dilepaskan kendaraan bermotor yang diakibatkan oleh kepadatan Jalan Prof. Dr. Hamka, Jalan Khatib Sulaiman, dan Jalan Rasuna Said, Kota Padang. Jenis penelitian ini adalah deskriptif 
kuantitatif dengan menggunakan data primer untuk melihat volume kendaraan, kadar karbon monoksida (CO), dan meteorologi. Data yang diperoleh di lapangan diolah dengan menggunakan rumus dari Interval untuk jumlah kendaraan, rumus ISPU (Indeks Standar Pencemaran Udara) untuk karbon monoksida (CO) di udara. Hasil penelitian menemukan bahwa, (1) kepadatan tertinggi terjadi di ruas Jalan Khatib Sulaiman dihari Senin total jumlah kendaraan 13125 unit kendaraan dengan lebar ruas jalan 3,50 meter. Kepadatan terendah di hari Sabtu di ruas Jalan Khatib Sulaiman total jumlah kendaraan 3826 unit kendaraan (2) konsentrasi gas CO tertinggi di Jalan Prof. Dr. Hamka sebesar 160,66 mg/m3 kategori udara tidak sehat, sedangkan konsentrasi terendah di Jalan Rasuna Said sebesar 26,67 mg/m3 kategori udara belum tercemar.

\subsubsection{Pengaruh Arah Angin Terhadap Dispersi Konsentrasi Karbon} Monoksida (CO) pada Udara Roadside di Kota Padang (Nurdahlia, 2017)

Penelitian Nurdahlia ini bertujuan untuk menganalisis hubungan konsentrasi Karbon monoksida (CO) dengan sudut datang angin dominan terhadap jalan $(\alpha)$, kecepatan angin (Va) dan karakteristik lalu lintas di Kota Padang meliputi volume lalu lintas (V), kecepatan lalu lintas (Vk) dan kepadatan lalu lintas (K), serta memetakan pola penyebaran konsentrasi CO saat jam puncak (17.00-18.00 WIB) menggunakan software Auto CAD. Sampling CO dilakukan di 3 titik pemantauan yang mewakili sudut datang angin dominan terhadap jalan yaitu di Jl. Jend. A. Yani, Jl. Andalas dan Jl. Prof. Dr. Hamka untuk dibuatkan model matematis konsentrasi $\mathrm{CO}$. Sampling konsentrasi $\mathrm{CO}$ di 3 titik pemantauan menggunakan alat impinger dan dianalisis dengan menggunakan spektrofotometer. Konsentrasi CO prediksi untuk pemetaan diperoleh dari uji statistika terhadap V, Vk, K, Va dan $\alpha$ di 40 titik pemantauan pada jam puncak. Hasil penelitian di ketiga lokasi pemantauan menunjukkan konsentrasi CO berkisar antara 137,217 - 600,525 $\mu \mathrm{g} / \mathrm{Nm}^{3}$. Konsentrasi tertinggi berada di Jl. Prof. Dr. Hamka sebesar $600,525 \mu \mathrm{g} / \mathrm{Nm}^{3}$ dengan $\alpha$ sebesar $60^{\circ}$ dan konsentrasi terendah berada di J1. Jend. A. Yani sebesar $137,217 \mu \mathrm{g} / \mathrm{Nm}^{3}$ dengan $\alpha$ sebesar $0^{\circ}$. Penurunan konsentrasi CO paling signifikan dari $\alpha=90^{\circ}$ ke $\alpha=0^{\circ}$ sebesar $64,62 \%$ pada volume lalu lintas dan $65,50 \%$ pada kepadatan lalu lintas. Dispersi konsentrasi CO di Kota Padang yaitu dominan ke arah barat sebesar $24,659-855,872 \mu \mathrm{g} / \mathrm{Nm}^{3}$. 


\section{BAB III}

\section{METODOLOGI PENELITIAN}

Penelitian ini terdiri dari beberapa tahapan dimulai dari studi literatur, pengumpulan data primer, pengumpulan data sekunder dan analisis data serta penarikan kesimpulan dan saran. Langkah-langkah pelaksanaan penelitian ini dapat dilihat pada Gambar 3.1 berikut:

\section{Mulai}

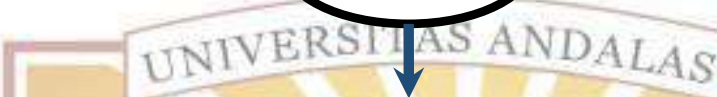

Studi Literatur

\section{Pengumpulan Data Primer}

1. Data Jumlah Pohon dan Karakteristik Pohon pelindung di Jl. Prof. Hamka dan Jl. Rasuna Said Kota Padang.

\section{Pengumpulan Data Sekunder}

1.Pengumpulan data karakteristik lalu lintas dan faktor meteorologi yang memengaruhi $\mathrm{CO}$ di udara roadside;

2. Pengumpulan data reduksi $\mathrm{CO}$ oleh pohon pelindung;

3. Hasil dan kesimpulan pada penelitian terkait.

\section{Analisis Data}

1. Menganalisis karakteristik lalu lintas yang memengaruhi konsentrasi CO dari hasil penelitian jurnal terkait;

2. Menganalisis faktor meteorologi (suhu, kelembapan udara, kecepatan dan arah angin) yang memengaruhi konsentrasi $\mathrm{CO}$ dari hasil penelitian jurnal terkait

3. Menganalisis Pohon pelindung yang mereduksi CO

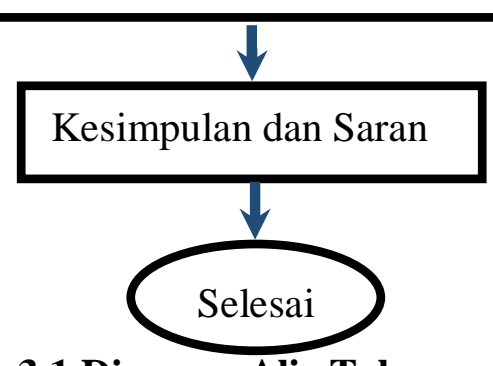

Gambar 3.1 Diagram Alir Tahapan Penelitian 


\subsection{Studi Literatur}

Studi literatur adalah tahap yang dilakukan untuk mencari serta memahami teori yang relevan terhadap ruang lingkup penelitian. Hal ini sangat penting agar dasar dan tujuan awal penelitian dapat diperoleh. Studi literatur meliputi buku-buku terkait, jurnal-jurnal penelitian, peraturan-peraturan yang berlaku serta sumber lainnya yang dapat dipergunakan sebagai landasan teori dalam penelitian dan penulisan.

\subsection{Pengumpulan Data}

Pada tahap ini dilakukan pengumpulan data-data yang digunakan untuk penelitian. Data-data tersebut berupa data primer dan data sekunder. Data primer pada penelitian ini merupakan data-data hasil observasi/pengamatan langsung di lapangan. Data sekunder didapatkan dari studi literatur dan dari sumber-sumber terkait. Kegiatan yang dilakukan di lapangan berupa observasi pada lokasi penelitian yaitu Jalan Prof. Hamka dan Jalan Rasuna Said untuk melihat kondisi jalan dan pohon pelindung di lokasi tersebut. Observasi lapangan dilakukan untuk mendata jumlah pohon pelindung serta mengidentifikasi karakteristik pohon pelindung yang di lokasi studi kasus.

Tabel 3.1 Jenis Data Keperluan Penelitian

\begin{tabular}{|l|l|l|l|l|}
\hline No. & Jenis Data & Parameter & Bentuk Data & Sumber Data \\
\hline 1. & Vegetasi & $\begin{array}{l}\text { Jumlah pohon, } \\
\text { kondisi lapang }\end{array}$ & Data primer & $\begin{array}{l}\text { Survey } \\
\text { lapangan }\end{array}$ \\
\hline 2. & Jalan & $\begin{array}{l}\text { Lokasi, ruas jalan, A } \\
\text { jumlah kendaraan }\end{array}$ & $\begin{array}{l}\text { Data primer } \\
\text { dan sekunder }\end{array}$ & $\begin{array}{l}\text { Survey } \\
\text { lapangan, } \\
\text { literatur }\end{array}$ \\
\hline 3. & Kualitas Udara & $\begin{array}{l}\text { Jumlah zat pencemar } \\
\text { CO di daerah studi } \\
\text { kasus, baku mutu CO }\end{array}$ & Data sekunder & literatur \\
\hline
\end{tabular}

Kemudian dilakukan pengumpulan data berupa Library research atau studi kepustakaan. Library research atau studi kepustakaan adalah teknik pengumpulan data yang digunakan dalam penelitian ini. Peneliti kemudian melakukan pengumpulan fakta dan data-data tertulis dari berbagai sumber. Data-data yang dikumpulkan adalah 
1. Data berisi karakteristik lalu lintas, faktor meteorologi (suhu, kelembapan udara dan kecepatan angin) dan konsentrasi CO di Jl. Prof. Hamka dan J1 Rasuna Said. Data ini dijadikan studi kasus dalam penelitian ini.

2. Data penelitian terkait karakteristik lalu lintas terhadap konsentrasi CO yang berguna sebagai acuan dalam menganalisis karakteristik lalu lintas terhadap konsentrasi CO di Kota Padang.

3. Data penelitian terkait faktor meteorologi (suhu, kelembapan udara dan kecepatan angin) terhadap konsentrasi CO digunakan untuk menganalisis studi kasus.

4. Data penelitian terkait pohon pelindung dalam mereduksi CO digunakan sebagai acuan dalam menganalisis studi kasus.

Tahap ini dilakukan dengan cara mengumpulkan jurnal penelitian yang berkaitan dengan pengaruh keberadaan pohon pelindung terhadap konsentrasi gas $\mathrm{CO}$. Untuk jurnal yang digunakan dalam penelitian ini dapat dilihat pada Tabel 3.2 berikut ini. Data sekunder berupa jurnal yang dikumpulkan ini dianalisis secara deskriptif.

Tabel 3.2 Jurnal yang Digunakan dalam Kajian Literatur

\begin{tabular}{|c|c|c|c|}
\hline No & Judul Artikel & Referensi & $\begin{array}{c}\text { Inti Sari Jurnal yang } \\
\text { Dibutuhkan }\end{array}$ \\
\hline 1 & $\begin{array}{l}\text { Pengaruh Kepadatan Kendaraan } \\
\text { Bermotor terhadap Konsentrasi } \\
\text { Karbon monoksida Ambien (Studi } \\
\text { Kasus Jalan Taman Siswa } \\
\text { Yogyakarta) }\end{array}$ & $\begin{array}{l}\text { Putra dan } \\
\text { Sudibyakto, } \\
2012 \\
\text { A A N }\end{array}$ & \\
\hline 2 & $\begin{array}{l}\text { Tingkat Pencemaran Udara CO } \\
\text { akibat Lalu Lintas dengan Model } \\
\text { Prediksi Polusi Udara Skala Mikro }\end{array}$ & $\begin{array}{l}\text { Sengkey dkk, } \\
2011\end{array}$ & \multirow[t]{2}{*}{$\begin{array}{l}\text { Pengaruh kepadatan } \\
\text { lalu lintas terhadap CO }\end{array}$} \\
\hline 3 & $\begin{array}{l}\text { Hubungan Kepadatan Lalu Lintas } \\
\text { dengan Konsentrasi CoHb pada } \\
\text { Masyarakat Berisiko Tinggi di } \\
\text { Sepanjang Jalan Nasional Kota } \\
\text { Semarang }\end{array}$ & $\begin{array}{l}\text { Anggraini, } \\
2016\end{array}$ & \\
\hline 4 & $\begin{array}{l}\text { Peranan Tanaman terhadap } \\
\text { Pencemaran Udara di Jalan Protokol } \\
\text { Kota Semarang }\end{array}$ & $\begin{array}{l}\text { Martuti, } \\
2013\end{array}$ & \multirow{3}{*}{$\begin{array}{l}\text { Pengaruh vegetasi } \\
\text { terhadap konsentrasi } \\
\mathrm{CO}\end{array}$} \\
\hline 5 & $\begin{array}{l}\text { Pengaruh Penghijauan Dalam } \\
\text { Mereduksi CO pada Daerah Traffic } \\
\text { Light Di Kota Pontianak }\end{array}$ & $\begin{array}{l}\text { Tifani, dkk, } \\
2015\end{array}$ & \\
\hline 6 & $\begin{array}{l}\text { Efektivitas Jalur Hijau Jalan dalam } \\
\text { Mengurangi Polutan Gas CO }\end{array}$ & $\begin{array}{l}\text { Izzah dkk, } \\
2019\end{array}$ & \\
\hline
\end{tabular}




\begin{tabular}{|c|l|l|l|}
\hline No & \multicolumn{1}{|c|}{ Judul Artikel } & Referensi & \multicolumn{1}{|c|}{$\begin{array}{l}\text { Inti Sari Jurnal yang } \\
\text { Dibutuhkan }\end{array}$} \\
\hline 7 & $\begin{array}{l}\text { The Impact of roadside vegetation } \\
\text { barriers on the dispersion of gaseous } \\
\text { traffic polution in urban street } \\
\text { canyons }\end{array}$ & Li dkk, 2016 & \\
\hline 8 & $\begin{array}{l}\text { The effects of vegetation barriers on } \\
\text { near-road ultrafine particle number } \\
\text { and carbon monoxide concentrations }\end{array}$ & $\begin{array}{l}\text { Lin dkk, } \\
2016\end{array}$ & \\
\hline 9 & $\begin{array}{l}\text { Carbon Sequestration by Urban } \\
\text { Trees on Roadsides of Vadodara City }\end{array}$ & $\begin{array}{l}\text { Kiran dan } \\
\text { Kinnary, } \\
2011\end{array}$ & \\
\hline 10 & $\begin{array}{l}\text { Analisis Pencemaran Udara Akibat } \\
\text { Kepadatan Jalan Lalu Lintas Kota } \\
\text { Padang (Studi Kasus: CO di Jalan } \\
\text { Prof Dr Hamka, J1 Khatib Sulaiman S S } \\
\text { dan Jalan Rasuna Said) }\end{array}$ & Wijaya, 2018 & $\begin{array}{l}\text { ANDALAS } \\
\text { lintas, data faktor } \\
\text { meteorologi dan data } \\
\text { konsentrasi CO pada } \\
\text { daerah studi kasus }\end{array}$ \\
\hline 11 & $\begin{array}{l}\text { Pengaruh Arah Angin Terhadap } \\
\text { Dispersi Konsentrasi Karbon } \\
\text { Monoksida (CO) pada Udara } \\
\text { Roadside di Kota Padang }\end{array}$ & Dahlia, 2014 & $\begin{array}{l}\text { Data konsentrasi CO } \\
\text { dan kelembapan udara } \\
\text { di daerah studi kasus }\end{array}$ \\
\hline
\end{tabular}

\subsection{Studi Kasus}

Lokasi yang dijadikan studi kasus adalah J1 Prof. Hamka dan J1 Rasuna Said Kota Padang. Pemilihan lokasi studi kasus ini dilakukan karena di kedua jalan termasuk ke dalam 10 jalan dengan kepadatan tertinggi di Kota Padang menurut Dinas Perhubungan tahun 2013. Jalan Prof. Dr. Hamka yang berada di Simpang Tunggul Hitam dan Jalan Rasuna Said merupakan lokasi titik penelitian yang dapat dilihat pada Gambar 3.2 dan Gambar 3.3 di bawah ini. Kedua jalan tersebut tepatnya terletak di Kecamatan Padang Utara dản Kècamatan Padang Barat berada di Jalan Rasuna Said. Berdasarkan data dari Dinas Prasarana Tata Ruang dan Permukiman, didapat informasi tentang jenis jalan di Kota padang berdasarkan ruas jalan, untuk lebih jelasnya dapat dilihat pada Tabel 3.3 berikut ini.

Tabel 3.3 Jenis Jalan Berdasarkan Klasifikasi/Ruas Jalan di Kota Padang

\begin{tabular}{|c|l|c|c|c|l|}
\hline No & Nama Jalan & $\begin{array}{c}\text { Lebar Ruas } \\
\text { Jalan }(\mathbf{m})\end{array}$ & $\begin{array}{c}\text { Panjang } \\
\text { Ruas Jalan } \\
(\mathbf{k m})\end{array}$ & \multicolumn{1}{|c|}{ Tipe Ruas } & Jenis Jalan \\
\hline 1. & $\begin{array}{l}\text { Jl. Prof. Dr. } \\
\text { Hamka }\end{array}$ & 3,00 & $3,7 \mathrm{~km}$ & $\begin{array}{l}\text { 4 lajur terbagi/1 } \\
\text { arah }\end{array}$ & $\begin{array}{l}\text { Arteri } \\
\text { sekunder }\end{array}$ \\
\hline 2. & Jl. Rasuna Said & 3,50 & $0,88 \mathrm{~km}$ & 4 lajur tak terbagi & Arteri primer \\
\hline
\end{tabular}

Sumber: Dinas Prasjal Tarkim Prov. Sumbar 


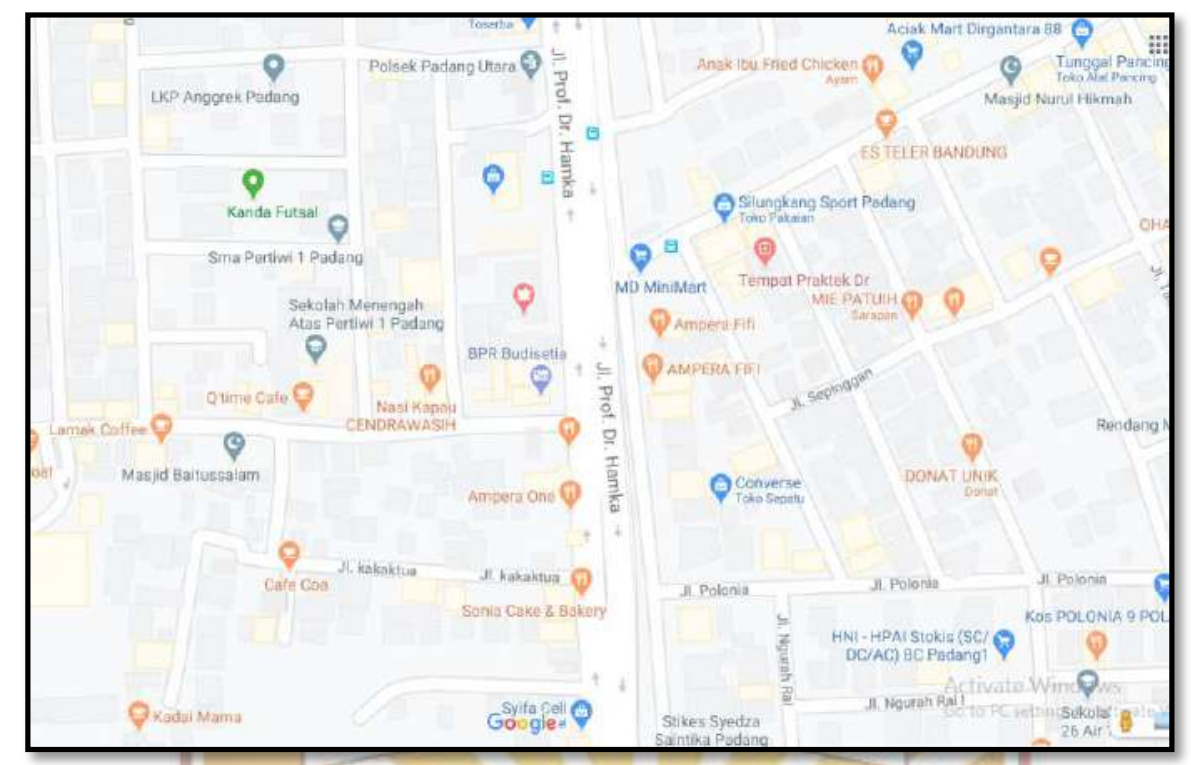

Gambar 3.2 Lokasi Penelitian di Jalan Prof. Dr. Hamka Kota Padang

(Sumber: Google Maps, 2020)

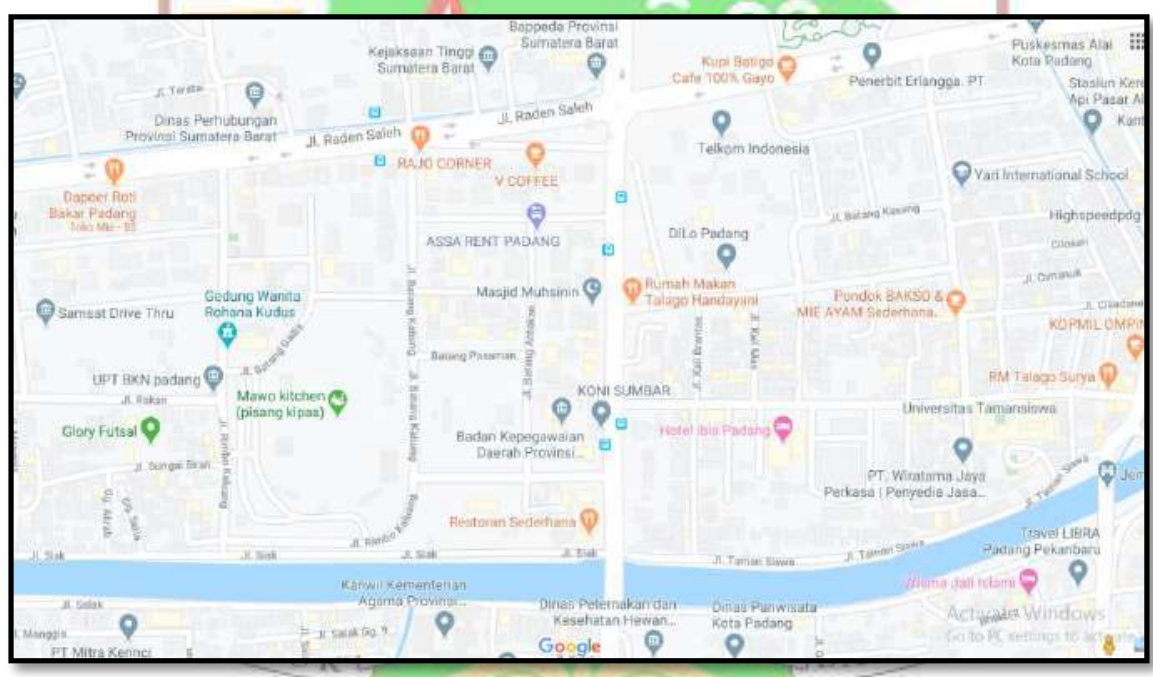

Gambar 3.3 Lokasi Penelitian di Jalan Rasuna Said Kota Padang

(Sumber: Google Maps, 2020)

Setiap lokasi sampling studi kasus memiliki hasil yang relatif sama, hal ini disebabkan oleh topografi dari masing-masing lokasi sampling tidak jauh berbeda, bisa dilihat dari ketinggian masing-masing lokasi sampling rata-rata $\pm 2-10 \mathrm{~m} \mathrm{di}$ atas permukaan laut. Faktor pohon pelindung di sepanjang jalan juga memengaruhi pemilihan lokasi penelitian, karena perbedaan banyaknya pohon pelindung di sepanjang jalan akan memengaruhi hasil dari pencemaran udara di sekitarnya menurut Dinas Lingkungan Hidup. 
Jumlah pohon pelindung yang ada di lokasi penelitian dihitung melalui google earth. Google earth merupakan aplikasi yang digunakan untuk melihat gambaran lokasi penelitian studi kasus (Jl Prof Hamka dan Jl Rasuna Said) dalam bentuk 3D. Street view untuk lokasi studi kasus dilakukan menggunakan google earth sehingga tidak diperlukan untuk menghitung pohon pelindung langsung ke lokasi studi kasus. Titik lokasi penelitian masing-masing dicari melalui google earth kemudian dibuka street view dalam bentuk 3D. Kemudian jumlah pohon pelindung dapat dihitung manual melalui street view dari google earth tersebut.

Masing-masing pohon pelindung yang ada di J1 Prof Hamka rata-rata berjarak 3-5 meter. Untuk daunnya tidak begitu lebat. Tinggi pohon yang ada di J1 Prof Hamka bervariasi dan masih ada yang terdiri dari pohon - pohon kecil. Untuk jumlah pohon pada jalan Prof Hamka ini adalah sebanyak 39 pohon. Pada Jl Rasuna Said terdapat 65 pohon pelindung yang ditanamiarak antar pohon di Jalan Rasuna Said rata-rata 2 meter. Kepadatan pohon di J1 Rasuna Said cukup tinggi, karena terdapat jumlah pohon yang banyak dengan panjang ruas jalan yang cukup pendek. Pohon yang dihitung berjarak 200 meter dari titik pengambilan sampel CO (Wijaya, 2018).

\subsection{Perhitungan Persentase Penurunan CO di Studi Kasus}

Data CO pada studi kasus Jl Prof Hamka dan Jl Rasuna Said didapatkan dari jurnal Wijaya (2018). Wijaya (2018) melakukan sampling selama 3 hari dan didapatkan data $\mathrm{CO}$ per jam selama 3 hari. Kemudian data $\mathrm{CO}$ dari masingmasing studi kasus dikonversi menjadi rata-rata konsentrasi $\mathrm{CO}$ per hari yang dapat dilihat pada Tabel 3.4 berikut ini:

Tabel 3.4 Persentase Penurunan CO oleh Jumlah Pohon Pelindung

\begin{tabular}{|c|c|c|c|c|c|}
\hline \multirow{2}{*}{$\begin{array}{c}\text { Hari/ } \\
\text { Tanggal }\end{array}$} & \multicolumn{4}{|c|}{ Konsentrasi Gas CO $\left(\boldsymbol{\mu g} / \mathbf{N m}^{\mathbf{3}}\right)$} & \multirow{2}{*}{$\begin{array}{c}\text { Persentasi } \\
\text { Penurunan (\%) }\end{array}$} \\
\cline { 2 - 5 } NAB CO & Jl. Prof Hamka & $\mathbf{( \% )}$ & Jl. Rasuna Said & $\mathbf{( \% )}$ & - \\
\hline Senin & 30.000 & 100 & 30.000 & 100 & $\mathrm{z}_{1}$ \\
\hline Rabu & $\mathrm{a}_{1}$ & $\mathrm{x}_{1}$ & $\mathrm{~b}_{1}$ & $\mathrm{y}_{1}$ & $\mathrm{z}_{2}$ \\
\hline Sabtu & $\mathrm{a}_{2}$ & $\mathrm{x}_{2}$ & $\mathrm{~b}_{2}$ & $\mathrm{y}_{2}$ & $\mathrm{z}_{3}$ \\
\hline *NAB CO berdasarkan PP No. 41 Tahun 1999 tentang Pengendalian Pencemaran Udara
\end{tabular}


Persentase untuk konsentrasi CO pada Jl Prof Hamka per hari dihitung dengan membuat perbandingan data konsentrasi $\mathrm{CO}$ per hari dengan nilai ambang batas $\mathrm{CO}$. Hal tersebut juga dilakukan untuk mencari persentase konsentrasi CO di Jl Rasuna Said. Setelah hasil persentase di Jl Prof Hamka dan Jl Rasuna Said didapatkan, kemudian dihitung selisih persentase kedua jalan tersebut untuk mendapatkan persentasi reduksi CO Jl Prof Hamka terhadap Jl Rasuna Said di Kota Padang.

$$
\begin{aligned}
& \mathrm{x} 1=\frac{\mathrm{a} 1(\mu \mathrm{g} / \mathrm{Nm} 3)}{30.000(\mu \mathrm{g} / \mathrm{Nm} 3)} \times 100 \\
& \mathrm{y} 1=\frac{\mathrm{b} 1(\mu \mathrm{g} / \mathrm{Nm} 3)}{30.000(\mu \mathrm{g} / \mathrm{Nm} 3)} \times 100 \ldots \ldots \ldots \ldots \ldots \ldots \ldots . \mathrm{S} . . . \cdots \cdots \ldots \ldots \ldots \ldots \\
& \mathrm{z} 1=\frac{\mathrm{x} 1}{\mathrm{y} 1} \times 100 \%
\end{aligned}
$$

Keterangan:

$\mathrm{x}=$ persentase gas CO Jl Prof Hamka $(\%)$

$\mathrm{y}=$ persentase gas CO J1 Rasuna Said (\%)

$\mathrm{z}=$ persentase penurusan gas $\mathrm{CO}$ oleh perbedaan pohon pelindung $(\%)$

\subsection{Analisis Data}

Analisis data dilakukan melalui beberapa tahap, sebagai berikut:

Pertama adalah tahap pengelompokan data. Data - data yang sudah dikumpulkan dikelompokan ke dalam beberapa kategori sesuai dengan alur penelitian ini. Awalnya data-data dikelompokan untuk dijadikan studi kasus terkait konsentrasi gas CO di udara ambien roadside, data-data pengaruh karakteristik lalu lintas terhadap konsentrasi CO, data-data pengaruh kondisi meteorologi (suhu, kelembapan udara dan kecepatan angin) terhadap konsentrasi CO, kemudian pengelompokan data-data terkait konsentrasi gas $\mathrm{CO}$ di udara roadside yang terdapat pohon pelindung.

Kedua adalah tahap reduksi data terhadap data-data yang sudah dikelompokan. Beberapa jurnal dijadikan studi kasus pada penelitian ini kemudian diseleksi berdasarkan relevansi terhadap penelitian ini sehingga didapatkan satu jurnal sebagai data studi kasus pada penelitian ini. Hasil seleksi tersebutlah yang kemudian dijadikan sebagai bahan dasar untuk melakukan analisis penelitian ini. 
Selain itu data tentang karakteristik lalu lintas, faktor meteorologi yang memengaruhi konsentrasi $\mathrm{CO}$ dan data reduksi konsentrasi $\mathrm{CO}$ oleh pohon pelindung digunakan sebagai pendalaman analisis pada penelitian ini.

Selanjutnya, tahap interpretasi dan penyajian data. Interpretasi dilakukan sebagai bentuk pemaknaan terhadap setiap bahan yang telah dikumpulkan dan kemudian data-data tersebut disajikan dalam bentuk deskripsi. Data studi kasus hasil seleksi dilakukan analisis konsentrasi $\mathrm{CO}$ terkait karakteristik lalu lintas dan faktor meteorologi (suhu, kelembapan udara dan kecepatan angin), kemudian dapat diprediksi bagaimana pengaruh pohon pelindung memengaruhi konsentasi $\mathrm{CO}$ pada studi kasus. Data berupa surnals penelitian terkait digunakan untuk mendukung analisis terhadap studi kasus pada penelitian ini. Terakhir adalah pengambilan kesimpulan. Hal ini dilakukan untuk melihat pengaruh keberadaan pohon pelindung terhadap konsentrasi gas $\mathrm{CO}$ di udara roadside jawaban dari penelitian ini. 


\section{BAB IV}

\section{PEMBAHASAN}

Tujuan dari tinjauan kajian ilmiah ini yaitu untuk mengumpulkan dan menilai semua literatur yang relevan tentang pengaruh pohon pelindung terhadap konsentrasi CO di udara roadside. Pembahasan yang dilakukan mengenai kualitas udara ambien roadside. Kualitas udara ambien roadside meliputi beberapa aspek yaitu karakteristik lalu lintas, faktor meteorologi dan pohon pelindung pereduksi polutan CO. Pencarian dan mengidentifikasi sejumlah studi yang cukup memenuhi kriteria yang dibahas: Studi yang dimasukkan adalah heterogen dalam hal protokol pengujian, intervensi, kondisi kontrol dan metode pengukuran hasil.

\subsection{Karakteristik Lalu Lintas Memengaruhi Kadar CO}

Volume kendaraan merupakan salah satu dari faktor yang memengaruhi kualitas udara roadside. Volume kendaraan dibedakan berdasarkan jenis kendaraan yaitu motor, mobil penumpang, dan bus, bisa dilihat pada Tabel 4.1 berikut. Mengetahui kepadatan kendaraan per hari dibutuhkan jumlah kendaraan di tiap jam. Aktifitas secara serentak di jalan raya yang dipenuhi oleh kendaraan akan mengakibatkan kepadatan lalu lintas. Studi kasus pada pembahasan kali ini diambil di Jalan Rasuna Said dan Jalan Prof. Hamka yang ada di Kota Padang. Kepadatan kendaraan di Jalan Prof. Hamka dan Jalan Rasuna Said dapat dilihat pada Tabel 4.2 di bawah ini.

Tabel 4.1 Volume Kendaraan di Ruas Jalan Prof. Dr. Hamka dan Jalan Rasuna Said Kota Padang

\begin{tabular}{|c|c|c|c|c|c|c|c|c|}
\hline \multirow{2}{*}{ No } & \multirow{2}{*}{$\begin{array}{l}\text { Nama } \\
\text { Jalan }\end{array}$} & \multirow{2}{*}{ Hari } & \multirow{2}{*}{$\begin{array}{c}\text { Waktu } \\
\text { Pengambilan }\end{array}$} & \multicolumn{3}{|c|}{$\begin{array}{c}\text { Volume Kendaraan } \\
\text { (unit) }\end{array}$} & \multirow{2}{*}{$\begin{array}{c}\text { Jumlah } \\
\text { Kendaraan/J } \\
\text { am (unit) }\end{array}$} & \multirow{2}{*}{$\begin{array}{c}\text { Total } \\
\text { Jumlah } \\
\text { Kendaraan } \\
\text { /hari (unit) }\end{array}$} \\
\hline & & & & Motor & Mobil & Bus & & \\
\hline \multirow{9}{*}{1.} & \multirow{9}{*}{$\begin{array}{l}\text { Jl. Prof. } \\
\text { Hamka }\end{array}$} & \multirow{3}{*}{ Senin } & $06.00-07.00$ & 2156 & 982 & 21 & 3159 & \multirow{3}{*}{12394} \\
\hline & & & $07.01-08.00$ & 3370 & 1736 & 18 & 5124 & \\
\hline & & & $08.01-09.00$ & 2784 & 1315 & 12 & 4111 & \\
\hline & & \multirow{3}{*}{ Rabu } & $06.00-07.00$ & 1372 & 683 & 12 & 2067 & \multirow{3}{*}{7948} \\
\hline & & & $07.01-08.00$ & 2511 & 1494 & 15 & 4020 & \\
\hline & & & $08.01-09.00$ & 1028 & 822 & 11 & 1861 & \\
\hline & & \multirow{3}{*}{ Sabtu } & $06.00-07.00$ & 628 & 439 & 10 & 1077 & \multirow{3}{*}{5029} \\
\hline & & & $07.01-08.00$ & 1416 & 923 & 13 & 2352 & \\
\hline & & & $08.01-09.00$ & 985 & 604 & 11 & 1600 & \\
\hline \multirow{2}{*}{2.} & \multirow{2}{*}{$\begin{array}{l}\text { Jl. Rasuna } \\
\text { Said }\end{array}$} & \multirow{2}{*}{ Senin } & $06.00-07.00$ & 1847 & 851 & 11 & 2709 & \multirow{2}{*}{9868} \\
\hline & & & $07.01-08.00$ & 2616 & 1473 & 16 & 4105 & \\
\hline
\end{tabular}




\begin{tabular}{|c|c|c|c|c|c|c|c|c|}
\hline \multirow{2}{*}{ No } & \multirow{2}{*}{$\begin{array}{l}\text { Nama } \\
\text { Jalan }\end{array}$} & \multirow{2}{*}{ Hari } & \multirow{2}{*}{$\begin{array}{c}\text { Waktu } \\
\text { Pengambilan }\end{array}$} & \multicolumn{3}{|c|}{$\begin{array}{c}\text { Volume Kendaraan } \\
\text { (unit) }\end{array}$} & \multirow{2}{*}{$\begin{array}{c}\text { Jumlah } \\
\text { Kendaraan/J } \\
\text { am (unit) }\end{array}$} & \multirow{2}{*}{$\begin{array}{c}\text { Total } \\
\text { Jumlah } \\
\text { Kendaraan } \\
\text { /hari (unit) }\end{array}$} \\
\hline & & & & Motor & Mobil & Bus & & \\
\hline & & & $08.01-09.00$ & 2083 & 958 & 13 & 3054 & \\
\hline & & \multirow{3}{*}{ Rabu } & $06.00-07.00$ & 1194 & 493 & 12 & 1699 & \multirow{3}{*}{8972} \\
\hline & & & $07.01-08.00$ & 2404 & 1876 & 14 & 4294 & \\
\hline & & & $08.01-09.00$ & 1705 & 1264 & 10 & 2979 & \\
\hline & & \multirow{3}{*}{ Sabtu } & $06.00-07.00$ & 1075 & 446 & 11 & 1532 & \multirow{3}{*}{7332} \\
\hline & & & $07.01-08.00$ & 1361 & 812 & 14 & 2187 & \\
\hline & & & $08.01-09.00$ & 2301 & 1299 & 13 & 3613 & \\
\hline
\end{tabular}

Sumber: Wijaya, 2018

Tabel 4.2 Data Kepadatan Lalu Lintas di Ruas Jalan Prof. Dr. Hamka dan Jalan Rasuna Said Kota Padang

\begin{tabular}{|r|c|c|c|c|}
\hline \multirow{2}{*}{ No } & Nama Jalan & Hari & $\begin{array}{c}\text { Total Jumlah Kendaraan/ } \\
\text { Jam (unit) }\end{array}$ & $\begin{array}{c}\text { Kepadatan/ } \\
\text { Hari }\end{array}$ \\
\hline \multirow{3}{*}{ 1. } & \multirow{3}{*}{ Jl. Prof. Hamka } & Senin & 12394 & Tinggi \\
\cline { 3 - 5 } & Rabu & 7948 & Sedang \\
\hline & & Sabtu & 5029 & Rendah \\
\hline \multirow{2}{*}{2.} & \multirow{2}{*}{ Jl. Rasuna Said } & Senin & 9868 & Tinggi \\
\cline { 3 - 5 } & & Rabu & 8972 & Sedang \\
\cline { 3 - 5 } & Sabtu & 7332 & Rendah \\
\hline
\end{tabular}

Sumber: Wijaya, 2018

Tabel 4.3 Data Konsentrasi CO di Ruas Jalan Prof. Dr. Hamka dan Jalan Rasuna Said Kota Padang

\begin{tabular}{|c|c|c|c|c|}
\hline No & Nama Jalan & Hari & Konsentrasi CO $(\mathbf{p p m})$ & $\mathbf{C O}\left(\boldsymbol{\mu g} / \mathbf{N m}^{\mathbf{3}}\right)$ \\
\hline \multirow{3}{*}{1.} & \multirow{3}{*}{ Jl. Prof. Hamka } & Senin & 15,33 & $17.555,83$ \\
\cline { 3 - 5 } & & Rabu & 9,00 & $10.306,74$ \\
\cline { 3 - 5 } & Sabtu & 5,67 & $6.493,25$ \\
\hline \multirow{2}{*}{2.} & Senin & 7,00 & $8.016,36$ \\
\cline { 3 - 5 } & \multirow{2}{*}{ Jl. Rasuna Said } & Rabu & 4,00 & $4.580,78$ \\
\cline { 3 - 5 } & & Sabtu & 2,67 & $3.057,67$ \\
\hline
\end{tabular}

Sumber: Wiijaya, 2018

Tabel 4.2 di atas menunjukan kepadatan kendaraan yang berturut-turut dari hari Senin, Rabu dan Sabtu pada 2 lokasi berbeda. Untuk melihat bagaimana pengaruh kepadatan kendaraan ini terhadap kadar CO di Jl Prof Hamka dan Jl Rasuna Said di Kota Padang dapat dilihat pada Tabel 4.2 dan Tabel 4.3. Didapatkan hasil bahwa semakin tinggi kepadatan kendaraan maka akan semakin tinggi juga kadar $\mathrm{CO}$ di beberapa jalan raya di Kota Padang. Sesuai dengan pernyataan Anggraini dkk (2016) bahwa ada hubungan yang kuat antara kepadatan lalu lintas dengan konsentrasi gas $\mathrm{CO}$ di beberapa jalan raya. Tingginya konsentrasi CO disebabkan oleh volume kendaraan pada jam-jam puncak yang mengeluarkan emisi. Hal ini didukung dalam penelitian sebelumnya (Sugiarta 2008) bahwa besar gas CO pada 
kendaraan bermotor menunjukkan korelasi yang positif dengan kepadatan lalu lintas sebagai penyumbang gas CO.

\subsection{Faktor Meteorologi pada Kualitas Udara Roadside}

Kondisi meteorologi merupakan salah satu faktor yang berpengaruh dalam pengukuran kualitas udara ambien. Kondisi meteorologi sangat memengaruhi besaran konsentrasi gas CO di lokasi pengukuran. Kondisi meteorologi yang diukur ketika pengukuran di lapangan meliputi: arah dan kecepatan angin $(\mathrm{m} / \mathrm{s})$, dan temperatur udara $\left({ }^{\circ} \mathrm{C}\right)$. Berdasarkan studi kasus di 2 jalan yang ada di Kota Padang yaitu Jl. Rasuna Said dan Jl. Prof. Hamka dapat dilihat pada Tabel 4.4 yang menampilkan data-data kon disi meteorologi pada studi kasus di Kota Padang berdasarkan penelitian Wijaya (2018).

Tabel 4.4 Data Kondisi Meteorologi dan Kadar CO di JI Prof. Hamka dan JI

\section{Rasuna Said}

\begin{tabular}{|c|c|c|c|c|c|c|c|}
\hline \multirow[b]{2}{*}{ No } & \multirow[b]{2}{*}{ Nama Jalan } & \multirow[b]{2}{*}{ Hari } & \multirow[b]{2}{*}{ Waktu } & \multicolumn{3}{|c|}{ Parameter Meteorologis } & \multirow{2}{*}{$\begin{array}{l}\text { Konsentrasi } \\
\mathrm{CO}\left(\boldsymbol{\mu g} / \mathrm{Nm}^{3}\right)\end{array}$} \\
\hline & & & & $\begin{array}{c}\text { Suhu } \\
\left({ }^{0} \mathrm{C}\right)\end{array}$ & $\begin{array}{c}\text { Kec. Angin } \\
(\mathrm{m} / \mathrm{s})\end{array}$ & Arah Angin & \\
\hline \multirow{9}{*}{1.} & \multirow{9}{*}{ Jl. Prof. Ha } & \multirow[b]{2}{*}{ Senin } & $\begin{array}{l}06.00- \\
07.00\end{array}$ & 26 & 0 & Barat laut & $5.725,97$ \\
\hline & & & $\begin{array}{l}07.01- \\
08.00\end{array}$ & 31 & 3 & Barat laut & $28.629,86$ \\
\hline & & \multirow{4}{*}{ Rabu } & $\begin{array}{c}08.01- \\
09.00 \\
\end{array}$ & 32 & 5 & Barat laut & $18.323,11$ \\
\hline & & & $\begin{array}{c}06.00- \\
07.00\end{array}$ & 27 & 0 & Barat laut & $3.435,58$ \\
\hline & & & $\begin{array}{l}07.01- \\
08.00\end{array}$ & 29 & 2 & Barat laut & $18.323,11$ \\
\hline & & & $\begin{array}{l}08.01- \\
09.00\end{array}$ & A31 & 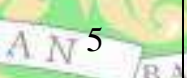 & Barat laut & $9.161,55$ \\
\hline & & \multirow{3}{*}{ Sabtu } & $\begin{array}{c}06.00- \\
07.00\end{array}$ & 26 & 0 & Barat laut & $2.290,39$ \\
\hline & & & $\begin{array}{l}07.01- \\
08.00\end{array}$ & 30 & 3 & Barat laut & $10.306,75$ \\
\hline & & & $\begin{array}{l}08.01- \\
09.00\end{array}$ & 32 & 6 & Barat laut & $6.871,17$ \\
\hline \multirow{6}{*}{2.} & \multirow{6}{*}{ Jl. Rasuna Said } & \multirow{3}{*}{ Senin } & $\begin{array}{c}06.00- \\
07.00\end{array}$ & 27 & 0 & Barat daya & $4.580,78$ \\
\hline & & & $\begin{array}{l}07.01- \\
08.00\end{array}$ & 30 & 4 & Barat daya & $13.742,33$ \\
\hline & & & $\begin{array}{c}08.01- \\
09.00\end{array}$ & 33 & 7 & Barat daya & $5.725,97$ \\
\hline & & \multirow{3}{*}{ Rabu } & $\begin{array}{c}06.00- \\
07.00\end{array}$ & 25 & 0 & Barat daya & 0 \\
\hline & & & $\begin{array}{l}07.01- \\
08.00\end{array}$ & 27 & 2 & Barat daya & $9.161,55$ \\
\hline & & & 08.01- & 30 & 4 & Barat daya & $4.580,78$ \\
\hline
\end{tabular}




\begin{tabular}{|c|c|c|c|c|c|c|c|}
\hline \multirow[b]{2}{*}{ No } & \multirow[b]{2}{*}{ Nama Jalan } & \multirow[b]{2}{*}{ Hari } & \multirow[b]{2}{*}{ Waktu } & \multicolumn{3}{|c|}{ Parameter Meteorologis } & \multirow[b]{2}{*}{$\begin{array}{l}\text { Konsentrasi } \\
\mathrm{CO}\left(\mu \mathrm{g} / \mathrm{Nm}^{3}\right)\end{array}$} \\
\hline & & & & $\begin{array}{l}\text { Suhu } \\
\left({ }^{0} \mathrm{C}\right)\end{array}$ & $\begin{array}{l}\text { Kec. Angin } \\
(\mathrm{m} / \mathrm{s})\end{array}$ & Arah Angin & \\
\hline & & & 09.00 & & & & \\
\hline & & & $\begin{array}{c}06.00- \\
07.00\end{array}$ & 27 & 0 & Barat daya & $1.145,19$ \\
\hline & & Sabtu & $\begin{array}{c}07.01- \\
08.00 \\
\end{array}$ & 32 & 3 & Barat daya & $4.580,78$ \\
\hline & & & $\begin{array}{c}08.01- \\
09.00\end{array}$ & 33 & 6 & Barat daya & $3.435,58$ \\
\hline
\end{tabular}

Sumber: Wijaya, 2018

Berikut penjabaran masing - masing faktor meteorologi terhadap kadar CO:

1. Suhu

Suhu mencerminkan energi kinetik rata-rata dari gerakan molekul-molekul. Suhu udara sangat peka terhadap perubahan radiasi matahari yang diterima permukaan bumi. Tutupan awan juga berpengaruh pada besarnya suhu di suatu daerah. Konsentrasi polutan dengan suhu udara memiliki hubungan yang hampir sama dengan radiasi matahari. Hal ini disebabkan semakin tinggi radiasi matahari yang sampai di permukaan, semakin tinggi juga suhu udara di permukaan. Pada siang hari suhu permukaan bumi lebih tinggi daripada suhu udara sehingga terjadi pemindahan panas dari permukaan bumi ke udara. Kondisi atmosfer menjadi tidak stabil sehingga memengaruhi dispersi polutan (Marhaeni, 2017).

Suhu udara pada Jl. Prof. Hamka dan Jl. Rasuna Said berkisar antara $25-33^{\circ} \mathrm{C}$.

Terlihat bahwa konsentrasi CO mengalami peningkatan pada jam 08.00-09.00 WIB yang diikuti dengan peningkatan konsentrasi CO. Sekitar 8,3\% variasi konsentrasi karbon monoksida dipengaruhi oleh variabel suhu udara (Putra dkk, 2012). Secara teoritis suhu udara yang tinggi akan mempercepat reaksi kimia dan meningkat produksi polutan CO secara cepat. Selain meningkatkan reaksi kimia, suhu udara juga akan meningkat jumlah emisi hidrokarbon di udara. Penguapan emisi hidrokarbon akibat kenaikan suhu udara dapat membuat terjadinya kontribusi ganda dalam pembentukan ozon permukaan. Dalam hal ini berarti suhu udara yang tinggi juga bertanggung jawab secara tidak langsung pada kenaikan konsentrasi CO di permukaan (Marhaeni, 2017). 
2. Arah dan Kecepatan Angin

Angin merupakan salah satu yang memengaruhi polutan karena polutan akan dibawa oleh angin pindah dari suatu tempat ke tempat lainnya. Di daerah urban, faktor angin menjadi sangat penting karena daerah perkotaan memiliki kekasaran permukaan yang tinggi sehingga dapat mengurangi kecepatan angin. Pengaruh kecepatan angin pada studi kasus sesuai dengan Tabel 4.4 adalah berbanding terbalik. Ketika kecepatan angin tinggi, maka kadar CO di kedua jalan pada studi kasus menjadi rendah. Kecepatan angin yang semakin tinggi akan membawa polutan seperti konsentrasi karbon monoksida ke tempat lain yang semakin jauh yang menyebabkan konsentrasi karbon monoksida akan semakin kecil karena polutan terbawa oleh angin (Putra dkk, 2012).

Angin akan bergerak lemah ketika malam hari. Hal ini karena terjadi adanya angin darat, yaitu ketika daratan sebagai penyimpan energi yang buruk membuat daratan menjadi lebih dingin (tekanan tinggi) daripada lautan (tekanan rendah), sehingga angin bergerak dari daratan ke lautan. Angin akan bertambah kecepatannya ketika matahari terbit dan berangsur membentuk puncak ketika energi radiasi matahari tertinggi. Proses terjadinya pencampuran bahan pencemar di udara dipengaruhi oleh kecepatan angin yang bergerak secara turbulen. Kecepatan angin juga sebagai penentu seberapa cepat pencemar bergerak menjauhi sumber (Ahren, 2007). Dapat dikatakan bahwa semakin besar kecepatan angin pada suatu kawasan maka akan mengakibatkan konsentrasi CO semakin rendah sesuai dengan kondisi CO pada studi kasus.

3. Kelembapan Udara

Kelembapan udara adalah banyaknya uap air yang terkandung dalam udara (Putra dkk, 2012). Kelembapan udara yang tinggi menunjukkan bahwa udara banyak mengandung uap air atau udara dalam keadaan basah. Kelembapan udara mencapai nilai minimum ketika radiasi matahari mencapai nilai maksimum. Secara teoritis kelembapan udara dapat dilihat melalui data suhu karena ketika suhu udara menurun, tekanan uap jenuh akan menaik dan udara menjadi lembab (Marhaeni, 2017). Pada siang hari, matahari menghasilkan energi radiasi yang kuat dan membuat suhu udara naik. Pada saat itu tekanan 
uap jenuh atau kapasitas udara untuk menampung uap air akan menurun, sehingga udara menjadi lebih kering.

Data kelembapan udara terhadap CO pada studi kasus didapatkan dari penelitian Dahlia (2018) di Jalan Prof. Dr. Hamka. Pengaruh kelembapan udara dengan konsentrasi CO pada studi kasus sesuai dengan Tabel 4.5 adalah berbanding lurus. Ketika kelembapan udara tinggi, maka kadar $\mathrm{CO}$ di jalan pada studi kasus menjadi tinggi.

Tabel 4.5 Data Kelembapan Udaran dan Konsentrasi CO di Jalan Prof Hamka Kota Padang

\begin{tabular}{|c|c|c|c|c|c|}
\hline No. & \multicolumn{2}{|c|}{ Hari/ Tanggal Sampling } & Waktu & Kelembapan (\%) & $\begin{array}{c}\text { Konsentrasi CO } \\
\left(\mu \mathrm{g} / \mathrm{Nm}^{3}\right)\end{array}$ \\
\hline & \multirow{10}{*}{ Rabu/ } & \multirow{10}{*}{$22-03-2017$} & $07.00-08.00$ & 100 & 533,033 \\
\hline & & & $08.00-09.00$ & 100 & 478,247 \\
\hline & & & $09.00-10.00$ & $30=$ & 511,976 \\
\hline & & & $10.00-11.00$ & 99,152 & 532,399 \\
\hline & & & $11.00-12.00$ & 98,886 & 562,754 \\
\hline & & & $12.00-13.00$ & 98,222 & 567,055 \\
\hline & & & $13.00-14.00$ & 98,396 & 564,571 \\
\hline & & & $14.00-15.00$ & 99,198 & 579,041 \\
\hline & & & $15.00-16.00$ & 98,822 & 571,994 \\
\hline & & & $16.00-17.00$ & 100 & 594,268 \\
\hline
\end{tabular}

Sumber: Dahlia, 2017

Polutan membutuhkan radiasi matahari untuk meningkatkan konsentrasi, sedangkan untuk meningkatkan kelembapan udara dibutuhkan radiasi matahari yang sedikit dan suhu udara yang rendah. Konsentrasi seperti CO secara umum akan bertambah ketika suhu udara meningkat dan kelembapan udara menurun. Pada malam hari, kelembapan udara akan meningkat hingga konsentrasi CO menurun. Kelembapan udara berbanding terbalik dengan konsentrasi CO, konsentrasi polutan rendah pada malam hari. Kelembapan udara maksimum juga dikaitkan dengan kemungkinan terjadinya hujan sehingga memunculkan kemungkinan terjadi pencucian polutan di atmosfer yang berakibat pada penurunan konsentrasi polutan di udara (Turyanti dan Santikayasa, 2006).

\subsection{Pengaruh Pohon Pelindung terhadap Konsentrasi CO}

Studi kasus pada penelitian ini ialah Jalan Rasuna Said dan Jalan Prof. Hamka di Kota Padang. Data hasil penelitian didapatkan dari data sekunder berupa jurnal 
penelitian Wijaya (2018) yang melakukan pengujian kadar CO di Jl. Rasuna Said, Jl. KH Sulaiman dan Jl. Prof Hamka. Data yang dibahas pada kajian literatur ini 2 jalan saja, yaitu Jl. Rasuna Said dan Jl. Prof Hamka, agar lebih jelas terlihat perbedaan banyak pohon yang memengaruhi kadar CO. Hasil sampling Wijaya (2018) dapat dlihat pada Tabel 4.6 berikut ini.

Tabel 4.6 Data Konsentrasi CO di Jl. Rasuna Said dan Jl. Prof. Hamka Kota Padang

\begin{tabular}{|c|c|c|c|c|}
\hline No & Nama Jalan & Hari & Waktu & $\begin{array}{c}\text { Konsentrasi CO } \\
\left(\mu \mathrm{g} / \mathrm{Nm}^{3}\right)\end{array}$ \\
\hline \multirow{9}{*}{1.} & \multirow{9}{*}{ Jl. Prof. Hamka } & \multirow[b]{2}{*}{ Senin } & $06.00-07.00$ & $5.725,97$ \\
\hline & & & $07.01-08.00$ & $28.629,86$ \\
\hline & & SI & S $08.01-09,00$ & $18.323,11$ \\
\hline & & \multirow{6}{*}{ Sabtu } & $06.00-07.00 \mathrm{~S}$ & $3.435,58$ \\
\hline & & & $07.01-08.00$ & $18.323,11$ \\
\hline & & & 08.01-09.00 & $9.161,55$ \\
\hline & & & $06.00-07.00$ & $2.290,39$ \\
\hline & & & $07.01-08.00$ & $10.306,75$ \\
\hline & & & $08.01-09.00$ & $6.871,17$ \\
\hline \multirow{9}{*}{2.} & \multirow{9}{*}{ Jl. Rasuna Said } & \multirow{3}{*}{ Senin } & $06.00-07.00$ & $4.580,78$ \\
\hline & & & 07.01-08.00 & $13.742,33$ \\
\hline & & & 08.01-09.00 & $5.725,97$ \\
\hline & & \multirow{3}{*}{ Rabu } & $06.00-07.00$ & 0 \\
\hline & & & 07.01-08.00 & $9.161,55$ \\
\hline & & & $08.01-09.00$ & $4.580,78$ \\
\hline & & \multirow{3}{*}{ Sabtu } & $06.00-07.00$ & $1.145,19$ \\
\hline & & & 07.01-08.00 & $4.580,78$ \\
\hline & & & 08.01-09.00 & $3.435,58$ \\
\hline
\end{tabular}

Sumbe: Wijaya, 2018

Tabel 4.7 Data Jumlah Pohon di Ruas Jalan Prof. Dr. Hamka dan Jalan Rasuna Said Kota Padang

\begin{tabular}{|c|c|c|}
\hline No & Nama Jalan & Jumlah Pohon \\
\hline 1. & Jalan Prof. Dr. Hamka & 39 \\
\hline 3. & Jalan Rasuna Said & 65 \\
\hline
\end{tabular}

Sumber: Perhitungan menggunakan Google Earth, 2020

Hasil penelitian Wijaya (2018) menunjukan bahwa kadar CO pada Jl. Prof. Hamka lebih tinggi daripada Jl. Rasuna Said. Pada Tabel 4.7 pohon terbanyak berada di sepanjang Jalan Rasuna Said dan kadar CO rata-rata lebih rendah dibandingkan Jl. Prof. Hamka yang memiliki sedikit pohon. Banyak pohon pelindung di sepanjang jalan memengaruhi konsentrasi $\mathrm{CO}$ akibat hasil pembakaran mesin kendaraan bermotor. Semakin banyak pohon pelindung yang ada di sepanjang jalan, maka akan semakin kecil pencemaran udara yang terjadi di jalan tersebut. 
Kurangnya pohon pelindung di Jalan Prof. Hamka mengakibatkan tingginya kadar $\mathrm{CO}$ yang didapat. Hal ini disebabkan oleh pohon pelindung yang mampu menurunkan konsentrasi gas pencemar yang melayang di udara, karena pohon dapat meningkatkan turbulensi aliran udara (Yulfida, 2012). Tajuk pohon yang tinggi dapat membelokkan hembusan angin ke atmosfir yang lebih luas, sehingga konsentrasi polutan menurun, melalui stomata polutan gas masuk kedalam jaringan daun sehingga kadar polutan yang diemisikan ke udara berkurang (Hanafri, 2011). Selain itu kadar CO yang lebih rendah juga disebabkan oleh polusi yang dihasilkan kendaraan diserap oleh pohon-pohon yang berada di sekitar jalan tersebut. Kendaraan yang melewati Jalan Prof. Dr. Hamka bisa mencapai 4131 kendaraan/jam, sehingga tiap kendaraan yang menghasilkan CO tidak dapat diserap secara keseluruhan oleh pepohonan yang ada di sekitar Jalan Prof. Hamka. Pohon pelindung terbukti mereduksi CO dibuktikan oleh penelitian Kiran dan Kinnary (2011) yang mengatakan bahwa pohon pelindung jalan raya yang ada berkontribuksi sebanyak 22\% mengurangi konsentrasi CO. Kemudian beberapa peneliti terkait juga menyatakan bahwa terjadi reduksi polutan $\mathrm{CO}$ oleh pohon pelindung atau vegetasi. Untuk lebih jelasnya dapat dilihat pada Tabel 4.8 di bawah ini.

Tabel 4.8 Data Reduksi CO oleh Pohon Pelindung

\begin{tabular}{|c|c|c|c|c|c|}
\hline No & Peneliti & Judul Penelitian & $\begin{array}{c}\text { Penurunan } \\
\text { Konsentrasi } \\
(\text { ppm })\end{array}$ & $\begin{array}{l}\text { Metode } \\
\text { Analisis }\end{array}$ & $\begin{array}{c}\text { Daerah yang } \\
\text { diteliti }\end{array}$ \\
\hline 1 & $\begin{array}{l}\text { Martuti } \\
(2013)\end{array}$ & $\begin{array}{c}\text { Peranan Tanaman } \\
\text { terhadap Pencemaran } \\
\text { Udara di Jalan Protokol } \\
\text { Kota Semarang }\end{array}$ & $\begin{array}{c}\mathrm{A} J(11,12 \mathrm{~V} \\
\mathrm{kg} / \text { pohon } / \\
\text { tahun })\end{array}$ & Line Intercept & $\begin{array}{c}\text { Kota } \\
\text { Semarang }\end{array}$ \\
\hline 2 & $\begin{array}{l}\text { Tiffani } \\
\text { dkk } \\
(2015)\end{array}$ & $\begin{array}{c}\text { Pengaruh Penghijauan } \\
\text { Dalam Mereduksi CO } \\
\text { pada Daerah Traffic Light } \\
\text { Di Kota Pontianak }\end{array}$ & $\begin{array}{c}\text { Tidak } \\
\text { dijelaskan }\end{array}$ & $\begin{array}{c}\text { Observasional } \\
\text { dengan } \\
\text { pendekatan } \\
\text { Cross Sectional }\end{array}$ & $\begin{array}{c}\text { Kota } \\
\text { Pontianak }\end{array}$ \\
\hline 3 & $\begin{array}{c}\text { Izzah dkk } \\
(2019)\end{array}$ & $\begin{array}{c}\text { Efektivitas Jalur Hijau } \\
\text { Jalan dalam Mengurangi } \\
\text { Polutan Gas CO }\end{array}$ & $8,5 \%$ & Uji Anova & Tol Cikampek \\
\hline 4 & $\begin{array}{l}\text { Li dkk } \\
(2016)\end{array}$ & $\begin{array}{c}\text { The Impact of roadside } \\
\text { vegetation barriers on the } \\
\text { dispersion of gaseous } \\
\text { traffic polution in urban } \\
\text { street canyons }\end{array}$ & $53 \%$ & $\begin{array}{l}\text { Model numerik } \\
2 \text { dimensi }\end{array}$ & Shanghai, Cina \\
\hline 5 & $\begin{array}{l}\text { Lin dkk } \\
(2016)\end{array}$ & $\begin{array}{c}\text { Pengaruh Vegetasi } \\
\text { terhadap Konsentrasi CO }\end{array}$ & $23-56 \%$ & $\begin{array}{l}\text { Perbandingan } \\
\text { SMPS }\end{array}$ & $\begin{array}{c}\text { North } \\
\text { Carolina, USA }\end{array}$ \\
\hline
\end{tabular}




\begin{tabular}{|c|c|c|c|c|c|}
\hline No & Peneliti & Judul Penelitian & $\begin{array}{c}\text { Penurunan } \\
\text { Konsentrasi } \\
(\mathbf{p p m})\end{array}$ & $\begin{array}{c}\text { Metode } \\
\text { Analisis }\end{array}$ & $\begin{array}{c}\text { Daerah yang } \\
\text { diteliti }\end{array}$ \\
\hline & & & & $\begin{array}{c}\text { Stasionari } \\
\text { dengan FMPS }\end{array}$ & \\
\hline
\end{tabular}

Banyak reduksi $\mathrm{CO}$ yang terjadi bervariasi pada setiap penelitian, tergantung kepada banyak pohon pelindung yang ada di ruas jalan, jenis pohon, tajuk pohon dan kecepatan angin pada saat melakukan pengukuran. Pada studi kasus Jl. Rasuna Said yang memiliki konsentrasi CO lebih rendah dibandingkan Jl. Prof. Hamka disebabkan oleh jumlah pohon dan kecepatan angin pada masing-masing jalan. Oleh karena itu, jalur hijau pada area jalan tol sebaiknya merupakan area tegakan vegetasi untuk mengurangi polutan gas CO. Semakin lebar area jalur hijau pada tepi jalan raya maka semakin tinggi kemampuan mengurangi tingkat konsentrasi gas CO (Izzah, 2019).

\subsubsection{Peranan Tanaman terhadap Pencemaran Udara roadside}

Pada penelitian Martuti (2013) jenis dan kerapata pohon yang ada di jalan utama Kota Semarang yang bisa dilihat pada Tabel 4.9, hasil dari pengamatan menunjukan bahwa terdapat 29 jenis vegetasi yang tertanam di 5 jalan utaman Kota Semarang. Untuk daerah Kalibanteng memiliki 15 jenis pohon pelindung dan yang paling mendominasi sebesar $29,5 \%$ lebih banyak dari pohn lainnya adalah pohon Angsana yang memiliki dengan tanaman Angsana. Jalan Pemuda memiliki 12 jenis pohon pelindung dan pohon Angsana juga mendominasi sebesar 29,4\% dari pohon pelindung lainnya. Angsana terbanyak terdapat di Jalan. Brigjen Katamso yang mana memiliki $67 \%$ lebih banyak dibandingan pohon pelindung lainnya. Hal yang berbeda terjadi di Jl. Kaligawe yang hanya memiliki 5 jenis pohon pelindung saja dan yang mendominasi sebesar 39,6\% adalah pohon glodokan. Pada Jl. Setiyabudi terdapat jenis pohon cemara yang mendominasi dari 12 jenis pohon pelindung lainnya yaitu sebesar 20,3\%. Tabel 4.9 di bawah ini menampilkan pohon pelindung yang ada di 5 jalan utama Kota Semarang. 
Tabel 4.9 Jenis dan Jumlah Tanaman Peneduh di Lima Jalan Protokol Kota Semarang

\begin{tabular}{|r|l|r|r|r|r|c|}
\hline \multirow{2}{*}{ No Nama Tanaman } & & \multicolumn{5}{|c|}{ Jumlah pada Stasiun } \\
\cline { 2 - 7 } & & $\mathbf{1}$ & $\mathbf{2}$ & $\mathbf{3}$ & $\mathbf{4}$ & $\mathbf{5}$ \\
\hline 1 & Akasia & 1 & 1 & - & - & - \\
\hline 2 & Andong & - & - & - & - & 1 \\
\hline 3 & Angsana & 70 & 46 & 59 & 2 & 8 \\
\hline 4 & Asam jawa & - & 5 & - & - & - \\
\hline 5 & Asam landi & 3 & 9 & - & - & - \\
\hline 6 & Beringin & 1 & 1 & - & 20 & 1 \\
\hline 7 & Bunga mentega & - & - & 2 & - & - \\
\hline 8 & Bougenviile & - & - & 2 & - & - \\
\hline 9 & Cemara & 13 & & 23 & - & -12 \\
\hline 10 & Cempaka & - & - & 1 & - & - \\
\hline 11 & Felicium & 2 & - & - & - & - \\
\hline 12 & Glodokan & 52 & 38 & 8 & 21 & 5 \\
\hline 13 & Johar & 1 & - & - & - & - \\
\hline 14 & Kamboja & - & - & 1 & - & - \\
\hline 15 & Kelapa & - & - & - & - & 1 \\
\hline 16 & Kembang dadap & 5 & 6 & - & - & - \\
\hline 17 & Kembang merak & - & 2 & - & - & - \\
\hline 18 & Kersen & - & - & 5 & - & 6 \\
\hline 19 & Mahoni & 27 & 1 & 6 & - & 2 \\
\hline 20 & Mangga & - & - & - & - & 1 \\
\hline 21 & Nangka & 1 & - & - & - & - \\
\hline 22 & Pakis & - & - & - & - & 3 \\
\hline 23 & Palem bojol & 11 & - & - & - & 7 \\
\hline 24 & Palem raja & 30 & 7 & - & - & 12 \\
\hline 25 & Palem rumpun & 19 & - & - & - & - \\
\hline 26 & Petai cina & - & 17 & 3 & - & - \\
\hline 27 & Pinus & 1 & - & - & - & - \\
\hline 28 & Trembesi & - & - & - & 8 & - \\
\hline 29 & Waru & & & 1 & 2 & - \\
\hline 5 & & & & \\
\hline
\end{tabular}

Sumber: Martuti,2013

Keterangan:

Setasiun 1: Bundaran Kalibanteng (237 pohon)

Setasiun 2: Tugu Muda (133 pohon)

Setasiun 3: Jalan Brigjen Katamso (111 pohon)

Setasiun 4: Jalan Kaligawe Semarang (53 pohon)

Setasiun 5: Jalan Setiabudi (59 pohon)

Hasil pengamatan kualitas udara dapat dilihat pada Tabel 4.10 di bawah ini. Martuti (2013) menyatakan dimana jenis pohon pelindung serta jumlah pada tiaptiap daerah penelitian berpengaruh negatif terhadap konsentrasi gas CO. Hasil negatif ini disebabkan oleh jenis yang terdapat pada lokasi penelitian tidak cocok dengan pohon pelindung yang efektif terhadap reduksi polutan gas CO. Sebaiknya 
dilakukan evaluasi kembali pada lokasi penelitian untuk pohon pelindung dengan jenis yang efektif terhadap pengurangan CO. Maka peran pohon pelindung sebagai penyerap polutan gas $\mathrm{CO}$ dapat terjadi dengan baik dan sesuai dengan yangg diharapkan. Berikut Tabel 4.10 hasil pengamanat Martuti (2013).

Tabel 4.10 Hasil Pengamatan Kualitas Udara Jalan Protokol Kota Semarang

\begin{tabular}{|c|c|c|c|c|c|c|}
\hline $\begin{array}{c}\text { Kualitas } \\
\text { Udara } \\
\left(\boldsymbol{\mu g} / \mathbf{N m}^{\mathbf{3}}\right)\end{array}$ & $\begin{array}{c}\text { Baku Mutu } \\
\left(\boldsymbol{\mu g} / \mathbf{N m}^{\mathbf{3}}\right)\end{array}$ & $\mathbf{1}$ & $\mathbf{2}$ & $\mathbf{3}$ & $\mathbf{4}$ & $\mathbf{5}$ \\
\hline CO & 30.000 & 25.763 & 21.469 & 15.028 & 8.588 & 19.179 \\
\hline Sumber: Martuti, 2013
\end{tabular}

Melihat terjadinya konsentrasi CO yang menurun pada studi kasus Jl. Rasuna Said menandakan bahwa pohon pelindung yang ada dil sekitar Jl. Rasuna Said sudah termasuk kepada jenis pohon pelindung yang mempunyai fungsi sebagai penjerap polutan udara. Berdasarkan pengamatan peneliti bahwa pohon tanjung merupakan pohon yang tertanam di Jl. Rasuna Said. Pohon Tanjung merupakan pohon yan memiliki efektivitas dalam menjerap polutan (Febri, 2011). Selain itu jumlah pohon pelindung yang ada di Jl. Rasuna Said juga memengaruhi konsentrasi CO pada penelitian ini.

\subsubsection{Pengaruh Penghijauan Dalam Mereduksi CO pada Daerah Traffic} Light

Menurut Tiffani (2015) yang melakukan penelitian tentang Pengaruh Penghijauan Dalam Mereduksi CO pada Daerah Traffic Light. Data pemeriksaan kadar CO pada daerah traffic light berjumlah 10 lokasi sampel penelitian yang di uji di Unit Pelayanan Hiperkes Pontianak dengan hasil tertinggi terdapat pada traffic light jalan Tanjung Pura (Hotel Garuda) dengan kadar CO yaitu 11.364,19 $\mu \mathrm{g} / \mathrm{Nm}^{3}$ dan paling terendah terdapat pada jalan Pak Kasih yaitu 4.264,21 $\mu \mathrm{g} / \mathrm{Nm}^{3}$. Hasil Pengukuran kadar CO pada sepuluh lokasi. Dari penelitian di dapatkan nilai katagori NAB dengan Nilai Ambang Batas CO $30.000 \mu \mathrm{g} / \mathrm{Nm} 3$ untuk pengukuran 1 jam berdasarkan Peraturan Pemerintah Nomor 41 Tahun 1999. dapat dilihat pada Tabel 4.11 bahwa 10 hasil sampel dari 10 lokasi yang berbeda menghasilkan nilai konsentrasi CO di bawah baku mutu dan dapat dikatakan aman. 
Tabel 4.11 Kadar CO pada Daerah Traffic light di Jalan Nasional Kota Pontianak

\begin{tabular}{|c|l|c|}
\hline No. & \multicolumn{1}{|c|}{ Nama Jalan } & Kadar $\mathbf{C O}\left(\boldsymbol{\mu g} / \mathbf{N m}^{\mathbf{3}}\right)$ \\
\hline 1 & Ahmad Yani (Polda) & $5.816,16$ \\
\hline 2 & Ahmad Yani (UNTAN) & $4.673,97$ \\
\hline 3 & Tanjung Pura (Hotel Garuda) & $11.364,19$ \\
\hline 4 & Tanjung pura (BII) & $9.047,33$ \\
\hline 5 & Pahlawan & $5.928,13$ \\
\hline 6 & Veteran & $7.764,74$ \\
\hline 7 & Perintis Kemerdekaan & $6.952,63$ \\
\hline 8 & Ya' Sabran & $8.396,77$ \\
\hline 9 & Situt Mahmud & $7,233,54$ \\
\hline 10 & Pak Kasih & $4.264,21$ \\
\hline
\end{tabular}

Sumber: Tiffani, 2015

Pada penelitian ini (Tiffani, 2015) dapat diketahui bagaimana pengaruh keberadaan pohon pelindung terhadap kadar CO. Peneliti melakukan analisis bivariat dengan uji korelasi. Hasil analisis bivariat antara keberadaan pohon dengan kadar CO pada daerah traffic light jalan Nasional kota Pontianak dapat dilihat pada Tabel 4.12 di bawah ini. Hasil menunjukan bahwa $r=0,067$ (korelasi sangat lemah) dengan $\mathrm{p}$ value $=0,788>0,05$ Ho diterima, jadi tidak ada pengaruh antara keberadaan pohon dengan kadar CO di traffic light kota Pontianak.

Tabel 4.12 Hasil Uji Korelasi Keberadaan Pohon dengan Kadar CO pada Daerah Traffic Light Jalan Nasional Kota Pontianak

\begin{tabular}{|c|c|c|c|c|}
\hline No & Variabel & N & R & Sig \\
\hline 1 & Keberadaan Pohon & 10 & 0,067 & 0,788 \\
\hline
\end{tabular}

Sumber: Tiffani, 2015

Tidak adanya pengaruh antara keberadaan pohon dengan kadar CO dapat dijelaskan bahwa dari hasil observasi di lapangan. Hasil observasi keberadaan pohon pelindung menunjukkan rata-rata jarak pohon cukup dekat dengan daerah traffic light, tetapi jarak antara satu pohon dengan pohon yang lain berbeda beda sehingga penyerapan kadar karbon di udara tidak terjadi dengan maksimal (Tiffani, 2015). Terdapat daerah yang memiliki keberadaan pohon dekat tetapi kadar CO tinggi dan juga terdapat wilayah yang memiliki keadaan kadar CO rendah tetapi keberadaan pohon jauh. Keadaan tersebut menunjukkan bahwa pohon yang berada di traffic light belum berfungsi cukup baik sebagai penyerap CO. Kemudian hasil observasi di lapangan juga terdapat jenis pohon yang kurang mampu menyerap polutan yaitu pohon pohon yang dipilih untuk keindahan tata kota. 
Berbeda dengan penelitian Tiffani (2015), keberadaaan pohon pelindung di Jl Rasuna Said memiliki pengaruh mereduksi polutan CO. Pohon pelindung pada Jl. Rasuna Said berjarak sekitar 2-3 meter antar pohon sehingga penyerapan kadar karbon di udara terjadi dengan maksimal.

\subsubsection{Efektivitas Jalur Hijau Jalan dalam Mengurangi Polutan Gas CO}

Menurut penelitian (Izzah, 2019) yang menjelaskan pada plot terbuka pada penelitian menghasilkan lebih banyak gas $\mathrm{CO}$ dibandingkan plot vegetasi yang ada. Wilayah vegetasi memiliki keefektivan yang sangat tinggi untuk pengurangan polutan gas CO. Didapatkan hasil dari perhitungan keefektivan area vegetasi dalam mereduksi CO adalah 8,5\% jika dilakukan perbandingan dengan area terbuka. Hasil penelitian Izzah (2019) menemukan bahwa hubungan CO dengan angin dalam area vegetasi memiliki hasil yang substansial. Plot terbuka yang tidak ditumbuhi tanaman menyebabkan hasil CO yang berbeda dengan plot vegetasi, hal ini disebabkan karena tidak adanya penyerapan $\mathrm{CO}$ pada plot terbuka yang dilakukan oleh tanaman sehingga tidak ada reduksi konsentrasi gas CO. Area bervegetasi CO pada area terbuka serta konsentrasi gas $\mathrm{CO}$ di kedua area mempunyai preferensi menurun dari sumber emisi $(0 \mathrm{~m})$ terhadap plot yang memiliki jarak yang lebih jauh. Hal ini menerangkan bahwa jalur hijau di tepi jalan sebaiknya memiliki area vegetasi yang tinggi untuk mereduksi konsentrasi gas CO. Tingkat konsentrasi gas CO akan berkurang ketika vegetasi pada suatu kawasan semakin luas. Izzah (2019) melakukan penelitian untuk melihat bagaimana jalur hijau memengaruhi reduksi konsentrasi gas CO dengan cara 2 metode of experience yaitu menguji eksistensi pohonn pelindung sebagai jalur hijau dan juga dilihat bagaimana jauh atau dekatnya vegetasi dari jalan. Pengolahan data yang dilakukan untuk melihat reduksi konsentrasi gas $\mathrm{CO}$ oeh vegetasi ini dilakukan metode statistika ANOVA. Berikut Tabel 4.13 dan Tabel 4.14 menampilkan hasil penelitian dari Izzah dkk (2019). 
Tabel 4.13 Rata - Rata Konsentrasi CO pada Tiga Waktu Dalam Plot Pada Pengambilan Sampel Udara

\begin{tabular}{|c|c|c|c|c|}
\hline \multirow{2}{*}{ Waktu } & \multirow{2}{*}{$\begin{array}{c}\text { Jumlah } \\
\text { kendaraan } \\
(\mathbf{s m p / j a m})\end{array}$} & $\begin{array}{c}\text { Area vegetasi } \\
\left(\boldsymbol{\mu g} / \mathbf{N m}^{\mathbf{3}}\right)\end{array}$ & $\begin{array}{c}\text { Area Terbuka } \\
\left(\boldsymbol{\mu g} / \mathbf{N m}^{\mathbf{3}}\right)\end{array}$ & \multirow{2}{*}{ Rata-rata } \\
\hline $10.00-11.00$ & 14.508 & $1.351,21$ & $1.943,32$ & $1.647,26$ \\
\hline $12.00-13.00$ & 13.190 & $1.219,26$ & $2.009,51$ & $1.614,39$ \\
\hline $14.00-15.00$ & 15.624 & $1.764,40$ & $2.195,91$ & $1.980,15$ \\
\hline
\end{tabular}

Sumber: Izzah dkk, 2019

Tabel 4.14 Perubahan Konsentrasi CO pada Jarak 0, 10 dan 30m

\begin{tabular}{|c|c|c|c|c|}
\hline \multirow{2}{*}{ Jarak (m) } & \multicolumn{4}{|c|}{ Konsentrasi Gas CO (mg/m3) } \\
\cline { 2 - 5 } & $\begin{array}{c}\text { Area vegetasi } \\
\left(\boldsymbol{\mu g} / \mathbf{N m}^{\mathbf{3}}\right)\end{array}$ & $(\boldsymbol{\%})$ & $\begin{array}{c}\text { Area Terbuka } \\
\left(\boldsymbol{\mu g} / \mathbf{N m}^{\mathbf{3}}\right)\end{array}$ & $(\boldsymbol{\%})$ \\
\hline 0 & $1.351,21$ & 100,00 & $1.943,32$ & 100,00 \\
\hline 10 & $1.219,26$ & 14,50 & $\mathbf{A} 2.009,51$ & 7,10 \\
\hline 30 & $1.764,40$ & 23,55 & $2.195,91$ & 15,05 \\
\hline
\end{tabular}

Sumber: Izzah dkk, 2019

Hal yang sama terjadi di Jl. Rasuna Said Kota Padang bahwa vegetasi berupa pohon pelindung yang berjumlah 65 buah dengan jarak antar pohon rata-rata 2 meter membantu mengurangi konsentasi CO. Pada jalan Prof. Hamka konsentasi $\mathrm{CO}$ bernilai tinggi disebabkan karena jumlah pohon pelindung yang sedikit dan jarak antar pohon yang cukup jauh (3-5 meter). Jarak antar pohon pelindung yang jauh membentuk jalur terbuka sehingga tidak terjadi pengurangan $\mathrm{CO}$ secara maksimal. Terbukti bahwa konsentrasi CO pada jalan Prof. Hamka tergolong tidak sehat.

\subsubsection{Pengaruh Tanaman Pelindung Jalan terhadap Penyebaran Gas Polusi} (CO) Lalu Lintas di Daerah Perkotaan

Menurut penelitian Li, dkk (2016) bahwa konsentasi CO lebih rendah pada jalan yang memiliki vegetasi. Hasil ini menunjukan bahwa terjadinya reduksi $\mathrm{CO}$ oleh vegetasi yang ada di pinggiran jalan. Penelitan ini juga menjelaskan bahwa vegetasi memperbaiki kualitas udara terutama konsentrasi $\mathrm{CO}$ di jalan raya. Keefektivan vegetasi dalam mereduksi CO disebabkan oleh beberapa faktor, yaitu tinggi vegetasi dan kecepatan angin. Hasil penelitian Li dkk (2016) ditunjukan oleh

Gambar 4.1 dibawah ini 


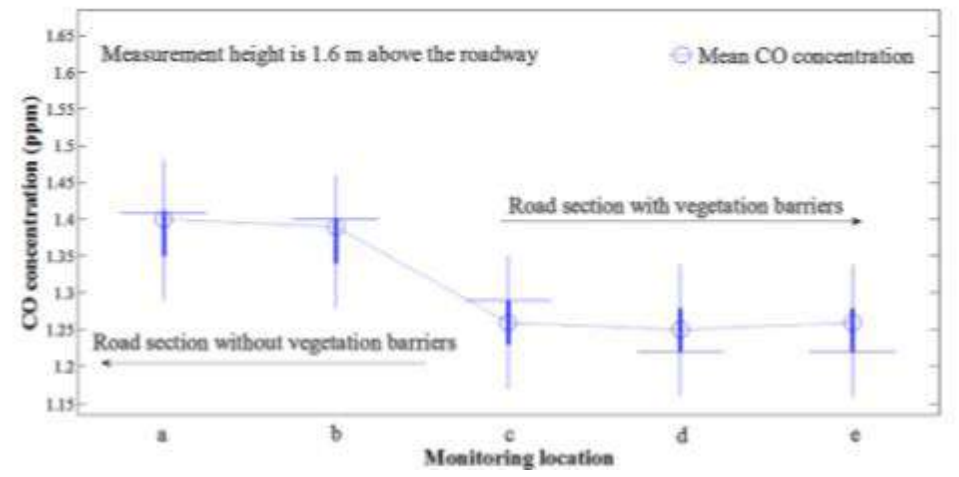

Gambar 4.1 Grafik Hasil Pengukuran CO terhadap Keberadaan Vegetasi (Sumber: Li dkk, 2016)

Penelitian ini relevan terhadap studi kasus di J1 Rasuna Said dan Jl Prof Hamka. Terdapat kesamaan berupa penurunan konsentrasi $L$ CO pada area vegetasi dan pohon pelindung. Tinggi tiap pohon pelindung pada J1 Rasuna Said mencapai 10 meter sedangkan di Jl Prof Hamka masih terdapat pohon yang masih rendah. Sehingga kondisi ini membuktikan bahwa tinggi vegetasi memengaruhi penurunan dari konsentrasi CO. Berdasarkan kecepatan angin pada studi kasus yang dapat dilihat pada Tabel 4.4 bahwa kecepatan angin di Jl. Rasuna angin rata-rata lebih tinggi dibandingkan kecepatan angin Jl Prof. Hamka. Jadi salah satu faktor penurunan konsentrasi CO di J1 Rasuna Said adalah kecepatan angin.

4.3.5 Pengaruh Hambatan Vegetasi berupa Pohon Pelindung terhadap Konsentrasi CO

Menurut penelitian Lin Dkk (2017) yang dapat dilihat pada Tabel 4.15 berikut ini, konsentrasi CO akibat vegetasi menunjukkan penurunan rata-rata 23,6-56,1\% seperti yang dapat dilihat pada Tabel 4.15 di bawah ini. Lin dkk (2017) melakukan penelitian dengan melakukan pengukuran pada 2 jalan berbeda di daerah Chapel Hill dan Mebane. Rata-rata tinggi pohon pelindung di daerah Chapel Hill adalah 48 meter sedangkan tinggi pohon di Mebane berkisar dari 6 sampai 8 meter. Ratarata luas vegetasi di Chapel hill juga lebih rendah dibanding Mebane. Chapel Hill memiliki luas vegetasi sekitar 2-5 m sedangkan luas vegetasi di Mebane mencapai 3-6 m. Besar kecilnya luas vegetasi disebabkan oleh banyak sedikitnya jumlah pohon dan banyak sedikitnya daun yang ada pada pohon pelindung. Hasil Reduksi CO rata-rata lebih besar di Mebane dibanding Chapel Hill yang salah satu 
faktornya adalah tinggi pohon pelindung. Semakin tinggi pohon pelindung semakin besar tingkat reduksi yang terjadi.

Tabel 4.15 Pengurangan Konsentrasi CO oleh Pengaruh Vegetasi di Kota Chapel Hill dan Kota Mebane

\begin{tabular}{|c|c|c|}
\hline Daerah sampling & Tanggal sampling & Reduksi CO (\%) \\
\hline \multirow{3}{*}{ Chapel hill } & $11 / 20$ & 18,11 \\
\cline { 2 - 3 } & $11 / 25$ & 18,89 \\
\cline { 2 - 3 } & $12 / 03$ & 23,57 \\
\hline \multirow{3}{*}{ Mebane } & $10 / 13$ & 56,05 \\
\cline { 2 - 3 } & $12 / 12$ & $-8,85$ \\
\cline { 2 - 3 } & $12 / 22$ & 17,5 \\
\hline
\end{tabular}

(Sumber: Lin Dkk, 2017)

Berdasarkan studi kasus di Kota Padang bahwa vegetasi yang ada di J1 Rasuna Said lebih banyak dibanding Jl Prof Hamka seperti yang terjadi di Mebane dan Chapel Hill. Maka terbukti bahwa konsentrasi CO di Jl Rasuna Said lebih kecil dibandingkan J1 Prof Hamka dipengaruhi oleh jumlah vegetasi atau jumlah pohon pelindung yang ada di sekitar jalan raya.

\subsection{Reduksi CO di Kota Padang}

Persentase reduksi CO yang terjadi di J1 Rasuna Said dapat diperkirakan melalui Tabel 4.16 berikut ini. Nilai 100\% diambil dari Baku mutu CO menurut PP No. 41 Tahun 1999 yaitu $30.000 \mu \mathrm{g} / \mathrm{Nm}^{3}$. Kemudian didapatkan juga persentasi kadar $\mathrm{CO}$ rata-rata perhari di J1 Rasuna Said yang ditanami 65 pohon pelindung. Kemudian didapatkan selisih persentase CO antara J1 Prof Hamka dengan Jl Rasuna Said per hari yang berarti nilai ini merupakan persèntase reduksi $\mathrm{CO}$ akibat jumlah pohon pelindung pada lokasi sampling. Metode ini didapatkan berdasarkan penelitian Izzah dkk (2019) yang dapat dilihat pada Tabel 4.16. Izzah dkk (2019) mendapatkan persentasi reduksi $\mathrm{CO}$ oleh jalur vegetasi yang juga dipengaruhi jarak pengambilan sampel $(0,10,30 \mathrm{~m})$ sedangkan persentase reduksi $\mathrm{CO}$ oleh pohon pelindung pada Tabel 4.16 dipengaruhi oleh jumlah pohon pelindung.

Tabel 4.16 Rata-Rata Konsentrasi CO di JI Prof Hamka dan JI Rasuna Said

\begin{tabular}{|c|c|c|c|c|c|}
\hline \multirow[b]{2}{*}{$\begin{array}{c}\text { Hari/ } \\
\text { Tanggal }\end{array}$} & \multicolumn{4}{|c|}{ Konsentrasi Gas CO $\left(\mu \mathrm{g} / \mathrm{Nm}^{3}\right)$} & \multirow[b]{2}{*}{ Persentasi Penurunan (\%) } \\
\hline & $\begin{array}{l}\text { Jl. Prof } \\
\text { Hamka }\end{array}$ & $(\%)$ & $\begin{array}{l}\text { Jl. Rasuna } \\
\text { Said }\end{array}$ & $(\%)$ & \\
\hline Senin & $17.555,83$ & 58,52 & $8.016,36$ & 26,72 & 31,8 \\
\hline Rabu & $10.306,74$ & 34,36 & $4.580,78$ & 15,27 & 19,09 \\
\hline Sabtu & $6.493,25$ & 21,65 & $3.057,67$ & 10,19 & 11,45 \\
\hline
\end{tabular}


Berdasarkan Tabel 4.16 yang menunjukan persentase penurunan CO bahwa persentase reduksi tertinggi dengan nilai 31,8\% pada hari Senin. Dinyatakan bahwa jumlah pohon pelindung yang berjumlah 39 di J1 Prof Hamka menghasilkan CO sebesar 58\% dari nilai ambang batas CO menurut PP No. 41 tahun 1999 yaitu $30.000 \mu \mathrm{g} / \mathrm{Nm}^{3}$, sedangkan konsentrasi CO di Jl Rasuna Said bernilai 26,72\% dari nilai ambang batas CO di udara ambien menurut PP No 41 tahun 1999. Persentase penurunan $\mathrm{CO}$ merupakan selisih dari nilai konsentrasi CO di J1 Prof Hamka terhadap nilai konsentrasi CO di Jl Rasuna Said. Nilai persentase reduksi tertinggi yang didapatkan bernilai $31,8 \%$ sedangkan persentase reduksi terendah terjadi pada hari Sabtu dengan nilai $11,45 \%$. Perbedaan persentase reduksi CO terjadi karena perbedaan jumlah kendaraan pada masing - masing lokasi studi kasus.

\subsection{Kemampuan Pohon Pelindung dalam Menyerap Konsentrasi CO di Kota}

\section{Padang}

Variabel yang digunakan untuk menilai kesesuaian pohon berdasarkan fungsi ekologis dalam menyerap polusi diantaranya adalah kepadatan tajuk pohon, ketebalan daun, jumlah daun, serta jarak tanam terhadap pohon lain. Berdasarkan hasil penilaian kesuaian karakter fisik pohon terhadap fungsi ekologis dalam menyerap polusi yang dilakukan, pohon pelindung yang ada di Jl. Rasuna Said dapat dikatakan memiliki kemampuan menyerap polusi yang baik. Berdasarkan penilaian, rata-rata 65 pohon pelindung yang ada di J1 Rasuna Said memenuhi kriteria sangat sesuai. Sedangkan untuk kategori pohon pelindung yang rata-rata kurang sesuai dalam menyerap polusi berjumlah 39 pohon yang berada di J1 Prof Hamka.

Tabel 4.17 Skoring Kemampuan Pohon Pelindung dalam Menyerap Polusi di Jl Prof Hamka dan Jl Rasuna Said Kota Padang

\begin{tabular}{|c|c|c|c|c|c|c|c|}
\hline \multirow{2}{*}{$\begin{array}{c}\text { Lokasi } \\
\text { Pohon } \\
\text { Pelindung }\end{array}$} & \multirow{2}{*}{$\begin{array}{c}\text { Jumlah } \\
\text { Pohon } \\
\text { Pelindung } \\
\end{array}$} & \multicolumn{4}{|c|}{$\begin{array}{c}\text { Skoring kemampuan } \\
\text { menyerap polusi }\end{array}$} & \multirow{2}{*}{ Nilai } & \multirow{2}{*}{ Ket } \\
\hline & & A1 & A2 & A3 & A4 & & \\
\hline $\begin{array}{l}\text { Jl. Prof } \\
\text { Hamka }\end{array}$ & 39 & 2 & 3 & 2 & 1 & 50 & Kurang sesuai \\
\hline $\begin{array}{l}\text { J1. Rasuna } \\
\text { Said }\end{array}$ & 65 & 4 & 3 & 4 & 3 & 88 & Sangat sesuai \\
\hline
\end{tabular}

Keterangan :

A1 : Kepadatan tajuk

A2 : Daun tipis

A3 : Jumlah daun banyak

A4 : Jarak tanam rapat 


\section{BAB V}

\section{KESIMPULAN DAN SARAN}

\subsection{Kesimpulan}

Berdasarkan penelitian yang telah dilakukan, maka dapat disimpulkan hal-hal sebagai berikut:

1. Karakteristik lalu lintas di Jl Prof Hamka dan Jl Rasuna Said sangat memengaruhi kadar CO pada jalan raya. Tingginya volume kendaraan mengakibatkan semakin tinggi pula polusi $\mathrm{CO}$ pada udara di sekitar kendaraan.

2. Kondisi meteorologi seperti suhu, kecepatan angin dan kelembapan udara memengaruhi konsentrasi CO di Jl Prof Hamka dan J1 Rasuna Said Kota Padang. Peningkatan Suhu berbanding lurus dengan Kadar CO. Semakin tinggi kecepatan angin, maka kadar CO pada suatu kawasan semakin rendah. Kelembapan udara berbanding lurus dengan peningkatan kadar CO.

3. Keberadaan pohon pelindung di J1 Prof. Hamka dan J1. Rasuna Said Kota Padang berpengaruh terhadap terhadap penurunan konsentrasi CO. Persentase $\mathrm{CO}$ yang direduksi oleh pohon pelindung yang berjumlah $65 \mathrm{di}$ J1 Rasuna Said terbesar ialah 31,8\% jika dibandingkan dengan J1 Prof Hamka yang memiliki 39 pohon pelindung

\subsection{Saran}

Saran yang dapat diberikan untuk penelitian terkait tema ini selanjutnya yaitu:

1. Disarankan untuk melanjutkan penelitian ini dengan menambahkan jenis emisi gas buang kendaraan bermotor lainnya seperti $\mathrm{NO}_{x}, \mathrm{SO}_{\mathrm{x}}$ dan $\mathrm{HC}$;

2. Disarankan untuk melanjutkan penelitian ini dengan memperhitungkan jenis pohon pelindung secara langsung dalam mereduksi kadar $\mathrm{CO}$;

3. Pemerintah diharapkan dapat memperbanyak pohon pelindung di Kota Padang dengan mempertimbangkan kriteria pohon pelindung yang memiliki efektivitas tinggi dalam mereduksi gas $\mathrm{CO}$. 


\section{DAFTAR PUSTAKA}

Agnesia, W. 2010. Analisa Kandungan Timbal (Pb) pada Tanaman Peneduh Jalan di Kecamatan Medan Polonia Tahun 2010. Skripsi FKM USU

Ahrens CD. 2007. Meteorology Today: An Introduction to Weather, Climate, and the Environment. Ed. 8th. Canada (CA): Thomson Brooks/Cole.

Alhakim, A. H. 2014. Evaluasi Efektivitas Tanaman Dalam Mereduksi Polusi Berdasarkan Karakter Fisik Pohon Pada Jalur Hijau Jalan Pajajaran Bogor. Thesis. Bogor: Institut Pertanian Bogor

Anggraini, N. 2016. Hubungan Kepadatan Lalu Lintas dengan Konsentrasi $\mathrm{COHb}$ Pada Masyarakat BerisikoSTinggi di Sepanjang Jalan Nasional Kota Semarang. Thesis. Semarang: Universitas Diponegoro.

Antari, AARJ dan Sundra, IK. 2002. Kandungan Timah Hitam (Plumbum) Pada Tanaman Peneduh Jalan di Kota Denpasar. http://ejournal.unud. ac.id/abstrak/4.pdf. 4 Februari 2020

Badan Pengelolaan Lingkungan Hidup Daerah Jakarta, 2013. Zat - zat Pencemar Udara, Jakarta.

Badan Pengelolaan Lingkungan Hidup Daerah Jakarta, 2013. Pengertian Pencemaran Udara, Jakarta: BPLH Jakarta

Badan Pengendalian Dampak Lingkungan Jakarta (BPLHD). 2005 Pemantauan Kualitas Udara Ambien DKI Jakarta. Jakarta: BPLH Jakarta

Badan Pusat Statistik. 2020. Indonesia dalam angka 2020. www.bps.go.id diakses pada tanggal 30 Juni 2020 E D J A J A A N

Badan Pusat Statistik Kota Padang. 2017. Padang dalam Angka 2017. www.padangkota.bps.go.id. Diakses tanggal 19 Februari 2020

Badan Pusat Statistik Provinsi Sumatera Barat. 2020. Jumlah Penduduk Kota Padang.www.provinsisumaterabarat.sps.bps.go.id. Diakses tanggal 19 Februari 2020

Badan Lingkungan Hidup Kab. Bantul. 2013. Buku Kualitas Udara. Bantul: BLH Bantul.

Bayu, E. 2012. Pengaruh Kepadatan Kendaraan Bermotor Terhadap Konsentrasi Karbon Monoksida Ambien (Studi Kasus Jalan Taman Siswa Yogyakarta). Universitas Gajah Mada. Yogyakarta. 
Chandra, B. 2007. Pengantar Kesehatan Lingkungan. Penerbit Buku Kedokteran. Jakarta

Carpenter, PL, TD Walker, FO Lanphear. 1975. Plants in the Landscape. San Fransisco : W.H.Freeman and Company.

Nurdahlia. 2017. Pengaruh Arah Angin Terhadap Dispersi Konsentrasi Karbon Monoksida (CO) pada Udara Roadside di Kota Padang. Skripsi Jurusan Teknik Lingkungan Universitas Andalas

Dharmawan, W., Susanti, D. 2012. Pengukuran Sensitivitas Sensor Gas CO dari Material $\mathrm{WO}_{3}$ Hasi; Proses Sol Gel dan Kalsinasi Tterhadap Variasi Konsentrasi dan Temperatur Operasi. Surabaya: Institut Teknologi Sepuluh Nopember UNTVERSTTAS ANDALAS

Departemen Pekerjaan Umum. 2006. UU No. 26 Tahun 2007 Tentang Penataan Ruang. Jakarta: Dep. PU RI

Department of Transport UK, 1994. Manual of Environmental Appraisal.London: Department of Transport, HMSO.

Dinas Lingkungan Hidup Provinsi Sumatera Barat. 2017. Kualitas Udara. DLH Kota Padang.

Dinas Pertamanan dan Pemakaman Kota Bandung (2007). Rekapitulasi Ruang Terbuka Hijau di Kota Bandung Sampai Tahun 2006. Bandung: Dinas Pertamanan dan Pemakaman Kota Bandung

Endrayana, P. 2011. Jurnal tentang Simulasi Model Dispersi Polutan Karbon Monoksida di Pintu Masuk Tol. Pasca Sarjana Matematika, Jurusan Matematika. Institut Teknologi Sepuluh November. Surabaya.

Envi News. 2012. Upaya mengurangi emisi udara dari sektor transportasi, Pontianak. Badan Lingkungan Hidup Prov. Kalbar

Environmental Protection Agency. 2012. Motor Vehicle and Toxic Air Pollutants. New Hampshire: EPA Office of Transportation and Air Quality

European Environment Agency. 2017. Air Pollution Source. Copenhagen, Denmark: EEA Office

Fakuara, Y. 1986. Hutan Kota: Peranan dan Permasalahannya. Departeman Manajemen Hutan. Fakultas Kehutanan, IPB. Bogor.

Fardiaz, Srikandi. 2010. Polusi Air \& Udara. Yogyakarta: Kanisius. 
Grey, G.W. dan Deneke, F.I. (1978). Urban Forestry. John Wiley and Sons.

Hanafri, K.S. 2011. Analisis Manfaat Kanopi Pohon Dalam Mereduksi Polutan. Diakses 10 Januari 2020. repository.ipb.ac.id/.../A11ksh_BA B\%20II\%20Tin

Hendrasarie, N. 2007. Kajian Efektivitas Tanaman dalam Menjerap Kandungan Pb Udara. Jurnal Rekayasa Perencanaan 3 (2): 2007

Hidayat, IW. 2008. Evaluasi Jalur Hijau Jalan Sebagai Penyangga Lingkungan Sekitarnya dan Keselamatan Pengguna Jalan Bebas Hambatan Jagorawi [Tesis]. Program Pascasarjana Institut Pertanian Bogor. Tidak dipublikasikan.

Hobbs, F.D 1995. Perencanaan dan Teknik Lalu Lintas. Gajah Mada University Press, Yogyakarta

Ihsantika, Aliya. 2013. Pentingnya Penghijauan di Kota Jakarta. Bogor: IPB

Istirokhatun. 2016. Kontribusi Parameter Meteorologi dan Kondisi Lalu Lintas terhadap Konsentrasi Pencemar $\mathrm{NO}_{2}$ di Kota Semarang. Semarang: Universitas Dipenegoro.

Izzah, A. N., Nasrulah, N., Sulistyantara, B. 2019. Efektivitas Jalur Hijau dalam Mengurangi Polutan Gas CO. Jurnal Ilmu Pertanian Indonesia. Vol. 24 (4): 337-342, ISSN: 0853-4217. Institut Teknologi Pertanian.

Junaidi. 2002. Analisis Kumulatif Kadar Debu PT. Semen Andalas Indonesia di Lingkungan AKL DEPKES RI Banda Aceh. Medan: Universitas Sumatera Utara.

Karliansyah, NW. 1999. Klorofil Daun Angsana Dan Mahoni Sebagai Bioindikator Pencemaran Udara, Jurnal Lingkungan Dan Pembangunan 19 (4): 290-305.

Kementrian Perhubungan. 2012. Informasi Transportasi. Sekretariat Jenderal Pusat Data dan Informasi: Jakarta

Kiran, G. S., Kinnary, S. 2011. Pengurangan CO oleh Pohon Kota di Jalan Kota Vadodara. International Journal of Engineering Science and Technology, Vol. 3, No. 4, ISSN: 0975-5462. Faculty of Science. University of Baroda.

Kusminingrum, Nanny. 2008. Potensi Tanaman dalam Menyerap $\mathrm{CO}_{2}$ Dan $\mathrm{CO}$ untuk Mengurangi Dampak Pemanasan Global. Bandung. 
Li, X.B., Lu, Q.C., Lu, S.J. 2016. The Impact of Roadside Vegetasition Barriers on the Dispersion of Gaseous Traffic Polution in Urban Street Canyon. China: Ocean and Civil Engineering, Jiao Tong University.

Lin, M. Y., Hagler, G., Baldauf, R., Isakov, V., Lin, H. Y., Khlystov, A. 2016. Efek dari Hambatan Vegetasi pada Jumlah Partikel dan Konsentrasi CO. Science of the Total Environment. Desert research Institute, USA.

Majid. 2011. Racun Gas CO. http://Racun Gas Karbon Monoksida.pdf-Adobe Reader (18 Februari 2020)

Marhaeni, A D R. 2017. Pengaruh Faktor Meteorologi terhadap Fluktuasi Konsentrasi Konsentrasi PMIO dan $\mathrm{O}_{3}$ di DKI Jakarta.(Skripsi). Bogor: Departemen Geofisika dan Meteorologi FMIPA. Institut Pertania Bogor.

Martuti, N. K. T. 2013. Peranan Tanaman terhadap Pencemaran Udara di Jalan Protokol Kota Semarang. Biosaintifika 5 (1) (2013). Jurusan Biologi. FMIPA. Universitas Negeri Semarang.

Mansur, M dan Pratama, B. A. 2014. Potensi Serapan Gas Karbondioksida $\left(\mathrm{CO}_{2}\right)$ Pada Jenis-Jenis Pohon Pelindung Jalan (Potential Absorption of Carbon Dioxide $\left(\mathrm{CO}_{2}\right)$ in Wayside Trees). Bogor: Bidang Botani, Pusat Penelitian Biologi-LIPI

MKJI. 1997. Manual Kapasitas Jalan Indonesia (MKJI). Direktorat Bina Jalan Kota (BINKOT) Sweroad

Morlock, E. K. 1991. Perencanaan Teknik dan Perencanaan Transportasi (Terjemahan). Erlangga. Jakarta J A J A A N

Mulianto, R. M. 2005. Kesehatan Lingkungan. Yogyakarta: Graha Ilmu

Mukono, J. 2011. Aspek Kesehatan Pencemaran Udara. Surabaya: Airlangga University Press.

Nevers, N.D. 2017. Air Pollution Control Enggineering Third Edition. New York: Mcgraw-Hill, International Editions

Nasrullah, N, et al. 2001. Seleksi Tanaman Lanskap yang Berpotensi Tinggi Menyerap Polutan Gas $\mathrm{NO}_{2}$ dengan Menggunakan Gas $\mathrm{NO}_{2}$ Bertanda $15 \mathrm{~N}$. Bulletin Taman dan Lanskap Indonesia Vol. 4/1/2001 : 1-5 
Ningrum, I.S., Yoza, D., Arlita, T. 2016. Kandungan Timbal (Pb) pada Tanaman Peneduh di Jalan Tuanku Tambusai Kota Pekanbaru. Pekanbaru: Universitas Riau

Nisalah, R., Budiharjo, M. Arief dan Endro S. 2010. Analisis Pengaruh Kepadatan Lalu Lintas terhadap Konsentrasi Particulate Matter 10 (PM10). Semarang: Universitas Dipenegoro

Nugrahani, P dan Sukartiningrum. 2008. Indeks Toleransi Polusi Udara (APTI) Tanaman taman Median Jalan Kota Surabaya. Jurnal Pertanian Mapeta 10 (2) : 86-92

Patra, Astra Dwi. 2002. Faktor Tanaman dan Faktor Lingkungan yang Memengaruhi Kemampuan Tanaman Dalam Menyerap Polutan Gas $\mathrm{NO}_{2}$ [Tesis]. Program Pascasarjana Institut Pertanian Bogor.

Pemerintah Republik Indonesia. 1999. Peraturan Pemerintah Republik Indonesia No. 41 Tahun 1999 tentang Pengendalian Pencemaran Udara. Jakarta: Sekretaris Kabinet Republik Indonesia

Peraturan Menteri Negara Lingkungan Hidup No. 12 Tahun 2010. Petunjuk Teknis Evaluasi Kriteria Transportasi Berkelanjutan di Perkotaan. Jakarta: Kementrian Lingkungan Hidup

Putra, E.B.D., Sudibyakto, H.A. 2012. Pengaruh Kepadatan Kendaraan Bermotor terhadap Konsentrasi Karbon monoksida Ambien (Studi Kasus Jalan Taman Siswa Yogyakarta). Yogyakarta: Universitas Negeri Yogyakara

Rezki, N., Yusfi, M. Dan Yendri, D. 2012. Rancang Bangun Protoipe Penurangan Bahaya Gas Polutasn dalam Ruangan dengan Metode Elektrolisis Berbasis Mikrokontroler. Padang: Fakultas Teknik Informatika Universitas Andalas

Sastrawijaya. 2009. Pencemaran Lingkungan. Jakarta: Rineka Cipta

Sengkey, Jansen, Wallah. 2011. Tingkat Pencemaran Udara CO akibat Lalu Lintas dengan Model Prediksi Polusi Udara Skala Mikro. Jurnal Ilmiah Media Engineering. 1(2): 119-126.

Siringoringo, H. H, 2000. Kemampuan Beberapa Jenis Tanaman Hutan Kota Dalam Menjerap Partikulat Timbal. Buletin Penelitian Hutan

SNI 19-7119.9-2005. 2005. Udara Ambien - Bagian 9: Penentuan Lokasi Pengambilan Contoh Uji Pemantauan Kualitas Udara Roadside. Indonesia: BSN. 
Santosa, I. 2012. Model Pencemaran Udara dari Kendaraan Bermotor Menggunakan Metode volume Terhingga (Studi Kasus di Kota Bogor). Disertasi. Jurusan Agrometeorologi. Bogor: IPB

Saputra, Y.E. 2009. Karbon monoksia dan Dampaknya terhadap Kesehatan. http://COdandampaknya terhadap Kesehatan Chemistry.Org Situs Kimia Indonesia.htm ( 7 Februari 2020 )

Siahaan, J. 2012. Analisis Pengaruh Faktor Meteorologi Terhadap Konsentrasi Nitrogen Dioksida $\left(\mathrm{NO}_{2}\right)$ Dan Ozon $\left(\mathrm{O}_{3}\right)$ Permukaan Di Jagakarsa Dan Kemayoran Jakarta. Skripsi. Jakarta: Universitas Trisakti

Siswantoro, Lagiyono dan Siswiyanti. 2012. Analisa Emisi Gas Buang Kendaraan Bermotor 4 Tak Berbahan Bakar Campuran Premium dengan Variasi Penambahan Zat Aditif. Tegal: Universitas Pancasakti

Soedomo, M. 2001. Kumpulan Karya Ilmiah mengenai Pencemaran Udara. Penerbit ITB Bandung.

Soerjani. 1987. Lingkungan: Sumber Daya Alam dan Kependudukan dalam Pembangunan. Jakarta: UI Press

Sugiarta AAG. 2008. Dampak Bising dan Kualitas Udara pada Lingkungan Kota Denpasar. Jurnal Bumi Lestari. 8(2): 162-167.

Supriyadi, E. 2009. Penerapan Model Finite Length Line Source untuk Menduga Konsentrasi Polutan dari Sumber Garis (Studi Kasus: Jl. M.H. Thamrin, DKI Jakarta), Tugas Akhir. Bogor: Institut Pertanian Bogor.

Tifani, W. A., Purnomo, A., Hajimi. 2015. Pengaruh Penghijauan dalam Mereduksi CO pada Daerah Traffic Light di Kota Pontianak. Jurnal Kesehatan Lingkungan Vol. 7, No. 1, Hal. 69-73. Poltekkes Kemenkes Pontianak.

Tjasyono, H.K. 2004. Klimatologi Terapan. Bandung: Pionir Jaya.

Turyanti A, Santikayasa IP. 2006. Analisa pola unsur meteorologi dan konsentrasi polutan di udara ambien (studi kasus Kota Jakarta dan Bandung). J. Agromet Indonesia. 20(2): 25-37.

Wardhana, W.A. 2011. Dampak Pencemaran Lingkungan (Edisi Revisi). Yogyakarta: Penerbit Andi.

WHO. 2012. Global Adult Tobacco. Survey: Indonesia Report 2011. Jakarta: National Institue of Health Research and Development Ministry of Health 
Wijaya, P. I. 2018. Analisis Pencemaran Udara Akibat Kepadatan Jalan Lalu Lintas Kota Padang (Studi Kasus: CO di Jalan Prof Dr Hamka, Jalan Khatib Sulaiman, dan Jalan Rasuna Said). Jurnal Buana Vol. 2, No. 2 ISSN: 2615-2630. Program Studi Geografi Fakultas Ilmu Sosial. Universitas Negeri Padang.

Yulfida Y, Marsaulina I, Ashar T. 2012. Perbandingan Kadar CO dan Nitrogen Dioksida $\left(\mathrm{NO}_{2}\right)$ di Udara Ambien Berdasarkan Keberadaan Pohon Angsana (Pterocarpus Indicus) di Beberapa Jalan Raya di Kota Medan Tahun 2012. Universitas Sumatera Utara: Medan

Yuliastuti, A. 2008. Estimasi Sebaran Keruangan Emisi Gas Buang Kendaraan Bermotor Di Kota Semarang. Skripsi. Jurusan Perencanaan Wilayah Dan Kota. Semarang: Universitas Diponegoro. DALAS

Yang JJ, McBride, Zhou J, Sun Z. 2005. The urban forest in Beijing and its role in air pollution reduction. Urban Forestry \& Urban Regreening 3: 65 78 .

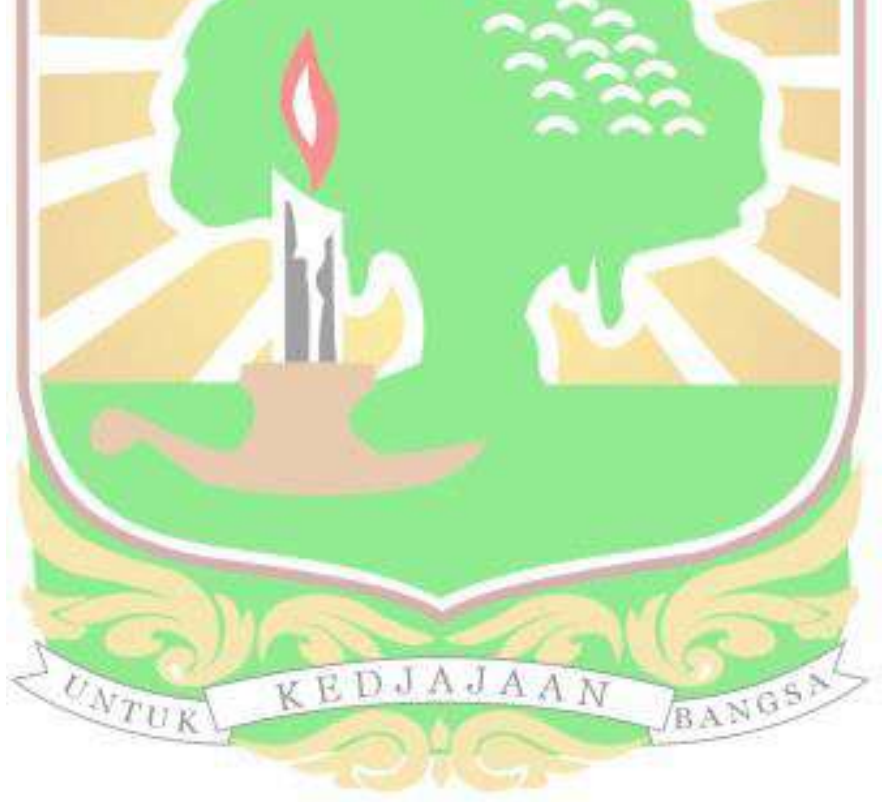


LAMPIRAN 


\section{LAMPIRAN A1}


LAMPIRAN A1

PERATURAN PEMERINTAH REPUBLIK INDONESIA

NOMOR

: 41 TAHUN 1999

TANGGAL : 26 MEI 1999

BAKU MUTU UDARA AMBIEN NASIONAL

\begin{tabular}{|c|c|c|c|c|c|}
\hline No & Parameter & $\begin{array}{c}\text { Waktu } \\
\text { Pengukuran }\end{array}$ & Baku Mutu & Metode Analisis & Peralatan \\
\hline 1 & $\begin{array}{l}\mathrm{SO}_{2} \\
\text { (Sulfur dioksida) }\end{array}$ & $\begin{array}{l}\text { 1 Jam } \\
24 \text { Jam } \\
1 \text { Tahun } \\
\end{array}$ & $\begin{array}{l}900 \mu \mathrm{g} / \mathrm{Nm}^{3} \\
365 \mu \mathrm{g} / \mathrm{Nm}^{3} \\
60 \mu \mathrm{g} / \mathrm{Nm}^{3} \\
\end{array}$ & Pararosanilin & Spektrofotometer \\
\hline 2 & $\begin{array}{l}\mathrm{CO} \\
\text { (Karbon } \\
\text { monoksida) }\end{array}$ & $\begin{array}{l}\text { 1 Jam } \\
\text { 24 Jam } \\
1 \text { Tahun }\end{array}$ & $\begin{array}{l}30.000 \mu \mathrm{g} / \mathrm{Nm}^{3} \\
10.000 \mu \mathrm{g} / \mathrm{Nm}^{3} \\
-\end{array}$ & NDIR & NDIR Analyzer \\
\hline 3 & $\begin{array}{l}\mathrm{NO}_{2} \\
\text { (Nitrogen } \\
\text { dioksida) } \\
\end{array}$ & $\begin{array}{l}\text { 1 Jam } \\
24 \text { Jam } \\
1 \text { Tahun }\end{array}$ & $\begin{array}{l}400 \mu \mathrm{g} / \mathrm{Nm}^{3} \\
150 \mu \mathrm{g} / \mathrm{Nm}^{3} \\
100 \mu \mathrm{g} / \mathrm{Nm}^{3}\end{array}$ & Saltzman & Spektrofotometer \\
\hline 4 & $\begin{array}{l}\mathrm{O}_{3} \\
\text { (Oksidan) }\end{array}$ & $\begin{array}{l}1 \text { Jam } \\
1 \text { Tahun }\end{array}$ & $\begin{array}{l}235 \mu \mathrm{g} / \mathrm{Nm}^{3} \\
50 \mu \mathrm{g} / \mathrm{Nm}^{3}\end{array}$ & Chemiluminescent & Spektrofotometer \\
\hline 5 & $\begin{array}{l}\mathrm{HC} \\
\text { (Hidrokarbon) }\end{array}$ & $3 \mathrm{Jam}$ & $160 \mu \mathrm{g} / \mathrm{Nm}^{3}$ & Flamed Ionization & Gas Chromatografi \\
\hline 6 & $\begin{array}{l}\mathrm{PM}_{10} \\
(\text { Partikel < } 10 \mu \mathrm{m})\end{array}$ & 24 Jam & $150 \mu \mathrm{g} / \mathrm{Nm}^{3}$ & Gravimetric & Hi-Vol \\
\hline & $\begin{array}{l}\mathrm{PM}_{2,5} \\
(\text { Partikel }<2,5 \mu \mathrm{m})\end{array}$ & $\begin{array}{l}24 \text { Jam } \\
1 \text { Tahun }\end{array}$ & $\begin{array}{l}65 \mu \mathrm{g} / \mathrm{Nm}^{3} \\
15 \mu \mathrm{g} / \mathrm{Nm}^{3}\end{array}$ & Gravimetric & $\mathrm{Hi}-\mathrm{Vol}$ \\
\hline 7 & TSP (Debu) & $\begin{array}{l}24 \text { Jam } \\
1 \text { Tahun }\end{array}$ & $\begin{array}{l}230 \mu \mathrm{g} / \mathrm{Nm}^{3} \\
90 \mu \mathrm{g} / \mathrm{Nm}^{3}\end{array}$ & Gravimetric & Hi-Vol \\
\hline 8 & $\mathrm{~Pb}$ (Timah Hitam) & $\begin{array}{l}\text { 24 Jam } \\
1 \text { Tahun }\end{array}$ & $\begin{array}{l}2 \mu \mathrm{g} / \mathrm{Nm}^{3} \\
1 \mu \mathrm{g} / \mathrm{Nm}^{3}\end{array}$ & $\begin{array}{l}\text { Gravimetric } \\
\text { Ekstraktif } \\
\text { Pengabuan } \\
\end{array}$ & $\begin{array}{l}\text { Hi-Vol } \\
\text { AAS }\end{array}$ \\
\hline 9 & $\begin{array}{l}\text { Dustfall } \\
\text { (Debu Jatuh) }\end{array}$ & 30 Hari & $\begin{array}{l}10 \text { Ton } / \mathrm{km}^{2} / \text { bulan } \\
\text { (pemukiman) } \\
20 \text { Ton } / \mathrm{km}^{2} / \mathrm{bulan} \\
\text { (industri) }\end{array}$ & Gravimetric & Cannister \\
\hline 10 & Total Fluorides $(\mathrm{F})$ & $\begin{array}{l}24 \text { Jam } \\
90 \text { Hari }\end{array}$ & $\begin{array}{l}3 \mu \mathrm{g} / \mathrm{Nm}^{3} \\
0,5 \mu \mathrm{g} / \mathrm{Nm}^{3}\end{array}$ & $\begin{array}{l}\text { Specific Ion } \\
\text { Electrode }\end{array}$ & $\begin{array}{l}\text { Impinger atau } \\
\text { Continuous analyzer }\end{array}$ \\
\hline 11 & Fluor Indeks & 30 Hari & $\begin{array}{l}40 \mu \mathrm{g} / \mathrm{cm}^{3} \text { dari } \\
\text { kertas lamed filter }\end{array}$ & Colorimetric & Limed Filter Paper \\
\hline 12 & $\begin{array}{l}\text { Khlorine \& } \\
\text { Khlorine dioksida }\end{array}$ & 24 Jam & $150 \mu \mathrm{g} / \mathrm{Nm}^{3}$ & $\begin{array}{l}\text { Specific Ion } \\
\text { Electrode }\end{array}$ & $\begin{array}{l}\text { Impinger atau } \\
\text { Continuous analyzer }\end{array}$ \\
\hline 13 & Sulfat Indeks & 30 Hari & $\begin{array}{l}1 \mathrm{mg} \mathrm{SO}_{2} / 100 \mathrm{~cm} 3 \\
\text { dari lead peroksida }\end{array}$ & Colorimetric & $\begin{array}{l}\text { Lead Peroxida } \\
\text { Candle }\end{array}$ \\
\hline
\end{tabular}

Catatan :

Nomor 10 s/d 13 Hanya di berlakukan untuk daerah/kawasan Industri Kimia Dasar

Contoh : - Industri Petro Kimia

- Industri Pembuatan Asam Sulfat. 


\section{LAMPIRAN A2}


Udara ambien - Bagian 9: Penentuan lokasi pengambilan contoh uji pemantauan kualitas udara roadside 



\section{Daftar isi}

Daftar isi

Prakata

ii

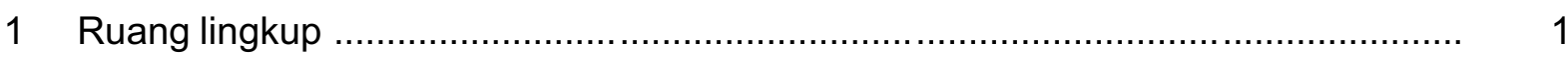

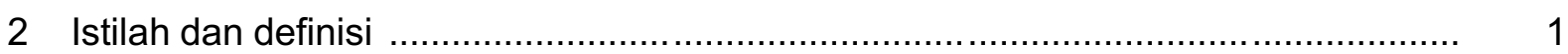

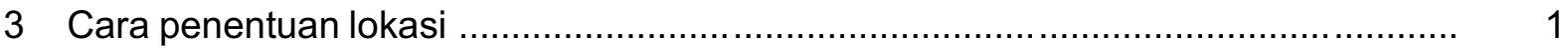

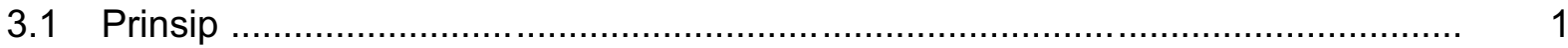

3.2 Persyaratan penempatan alat pengambilan contoh uji ...................................... 2

3.3 Langkah-langkah pengambilan contoh uji .................................................. 2

3.4 Pemantauan kondisi metrologis untuk stasiun tetap …..................................... 2

Lampiran A (normatif) Pelaporan ......................................................................... 5

Lampiran B (informatif) Penempatan alat dan titik sampling ......................................... 6

Lampiran C (informatif) Hal-hal yang dianggap perlu dalam pelaporan ......................... 7

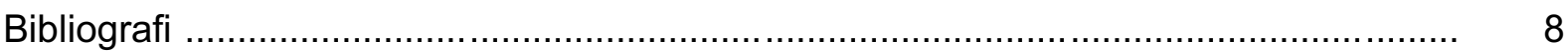




\section{Prakata}

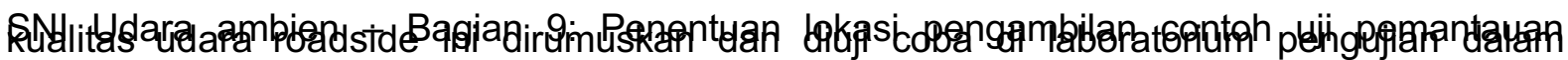
rangka validasi metode serta telah dikonsensuskan oleh Subpanitia Teknis Parameter Uji Kualitas Udara dari Panitia Teknis Sistem Manajemen Lingkungan (Panitia Teknis 207S).

Standar ini telah disepakati dan disetujui dalam rapat konsensus dengan peserta rapat yang mewakili produsen, konsumen, ilmuwan, instansi teknis, pemerintah terkait dari pusat maupun daerah pada tanggal 5-6 Agustus 2004 di Jakarta. 


\section{Udara ambien - Bagian 9: Penentuan lokasi pengambilan contoh uji pemantauan kualitas udara roadside}

Standar ini digunakan untuk menentukan titik pengambilan contoh uji kualitas udara ambien roadside yang meliputi:

a) Pemilihan lokasi pengambilan contoh uji pemantauan kualitas udara ambien dengan kriteria roadside.

b) Penempatan peralatan pengambil contoh uji pemantauan kualitas udara ambien kriteria roadside.

\section{$2 \quad$ Istilah dan definisi}

2.1 probe

sampel masuk contoh uji dari alat pengambilan contoh uji

\section{2}

roadside

daerah/lokasi jalan yang akan dipantau

\section{3}

stasiun road side

hotspot stasiun yang berlokasi di daerah yang sangat tajam konsentrasi polutannya dibandingkan dari daerah lainnya

\section{4}

absorpsi

penyerapan secara kimiawi oleh tumbuhan, bangunan dan penghalang lainnya terhadap contoh uji

\section{5}

adsorpsi

penyerapan secara fisika oleh tumbuhan, bangunan dan penghalang lainnya terhadap contoh uji

\section{6}

canyon

jalan raya seperti terowongan (sebagai contoh, jalan yang kedua tepinya dibatasi oleh bangunan tinggi)

\section{Cara penentuan lokasi}

\subsection{Prinsip}

Pemilihan lokasi dan penentuan titik pengambilan contoh uji, harus mewakili daerah yang

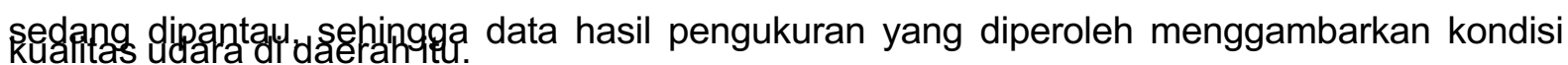




\subsection{Persyaratan penempatan alat pengambilan contoh uji}

Persyaratan yang digunakan untuk pemilihan lokasi dan titik pengambilan contoh uji adalah:

a) Pilih lokasi pengambilan contoh uji di stasiun roadside.

b) Tempatkan alat pengambil contoh uji yang alirannya bebas.

c) Tempatkan alat pengambil contoh uji pada lokasi yang tidak terpengaruh oleh peristiwa adsorpsi maupun absorpsi.

d) Tempatkan alat pengambil contoh uji di tempat yang aman yang bebas dari pengganggu fisika.

e) Hindari daerah yang rawan kerusuhan, bencana alam seperti banjir.

f) Perhatikan tipe jalan (lebar, sempit, canyon atau jalan tol, demikian juga persimpangan jalan, perhentian kendaraan)

CATATAN Lihat Lampiran B (informatif).

\subsection{Langkah-langkah pengambilan contoh uji}

a) Tempatkan peralatan pengambil contoh uji pada lokasi yang mempunyai prasarana seperti listrik.

b) Tempatkan peralatan pengambil contoh uji di daerah terbuka (gedung atau bangunan

b) yang rendah dan saling berjauhan).

c) Penempatan peralatan berjarak $1 \mathrm{~m}$ sampai dengan $5 \mathrm{~m}$ dari pinggir jalan yang akan diambil contoh uji dan pada ketinggian 1,5 m sampai dengan $3 \mathrm{~m}$ dari permukaan jalan.

d) Ukur kepadatan lalulintas dari jalan yang akan diambil contoh uji kemudian dikategorikan

d) kepadatan lalulintas (kurang 2000, 2000 - 10000 dan lebih dari 10000 kendaraan per hari).

Peta pedoman atau acuan dalam menentukan suatu lokasi pemantauan kualitas udara roadside:

Arah angin dominan

$$
\begin{aligned}
& \text { lokasi pengambilan } \\
& \text { Contoh uji }(1 \mathrm{~m}-5 \mathrm{~m})
\end{aligned}
$$

Jalan Raya

lokasi pengambilan

Contoh uji (1 m - 5 m)

\section{Gambar 1 Peta pedoman atau acuan dalam menentukan lokasi pemantauan kualitas udara roadside}

\subsection{Pemantauan kondisi meteorologis untuk stasiun tetap}

Untuk mendukung pemantauan kualitas udara roadside, perlu dilakukan pemantauan kondisi meteorologiss yang meliputi arah angin, kecepatan angin, kelembaban dan temperatur serta radiasi global. Sebelum pengukuran dimulai yakinkan penunjukan arah utara dari balingbaling alat. Penetapan lokasi pemantauan meteorologiss sebagai berikut: 
3.4.1 Ketentuan lokasi stasiun pemantau yang relatif dekat dengan jalannya bangunan atau pohon tertinggi (Gambar 2)

Pada bagian ini menjelaskan dimana jarak lokasi peralatan pemantau dengan bangunan dan pohon tertinggi, kurang dari 10 kali tinggi bangunan atau pohon tersebut.

a) Tinggi probe alat pemantau meteorologis (anemometer, $\mathrm{RH}$ meter etc) minimal 2,5 kali dari tinggi penghisap alat pemantau mutu udara ambien yang membentuk sudut $30^{\circ}$ terhadap bangunan atau pohon tertinggi.

b) Tinggi alat pemantau meteorologis (anemometer, $\mathrm{RH}$ meter etc) minimal $2 \mathrm{~m}$ lebih tinggi dari bangunan atau pohon tertinggi di sekitarnya.

c) Tinggi probe (sampling inlet) alat pemantau mutu udara minimal 1.5 - 3 meter.

Tinggi alat sensor (baling-baling etc.) peralatan pemantau kondisi meteorologiss minimal 10 meter dari permukaan tanah.

3.4.2 Ketentuan stasiun pemantau yang relatif jauh dari bangunan atau pohon tertinggi (jarak stasiun ke bangunan atau pohon tertinggi minimal 10 kali tinggi bangunan atau pohon tertinggi (gambar 3))

Pada bagian ini menjelaskan dimana jarak lokasi peralatan pemantau dengan bangunan dan pohon tertinggi, lebih kurang dari 10 kali tinggi bangunan atau pohon tersebut.

a) Tinggi alat pemantau meteorologis minimal 2,5 kali dari tinggi probe alat pemantau kualitas udara ambien

b) Tinggi probe (sampling inlet) alat pemantau mutu udara minimal 1.5 - 3 meter

c) Tinggi alat sensor (baling-baling etc.) peralatan pemantau kondisi meteorologiss minimal 10 meter dari permukaan tanah.

Anemometer

Sample inlet

Keterangan gambar:

a adalah tinggi sample inlet $(1,5 \mathrm{~m}-3 \mathrm{~m})$;

b adalah tinggi alat pemantau meteorologis (anemometer, $\mathrm{RH}$ meter etc) minimal 2,5 kali tinggi sampel inlet udara (minimal $10 \mathrm{~m}$ );

C adalah jarak shelter (tempat peralatan) dari pinggir jalan $(1 \mathrm{~m}-5 \mathrm{~m})$.

Gambar 2 Lokasi peralatan pemantau meteorologiss yang relatif dekat dengan bangunan atau pohon terting gi 


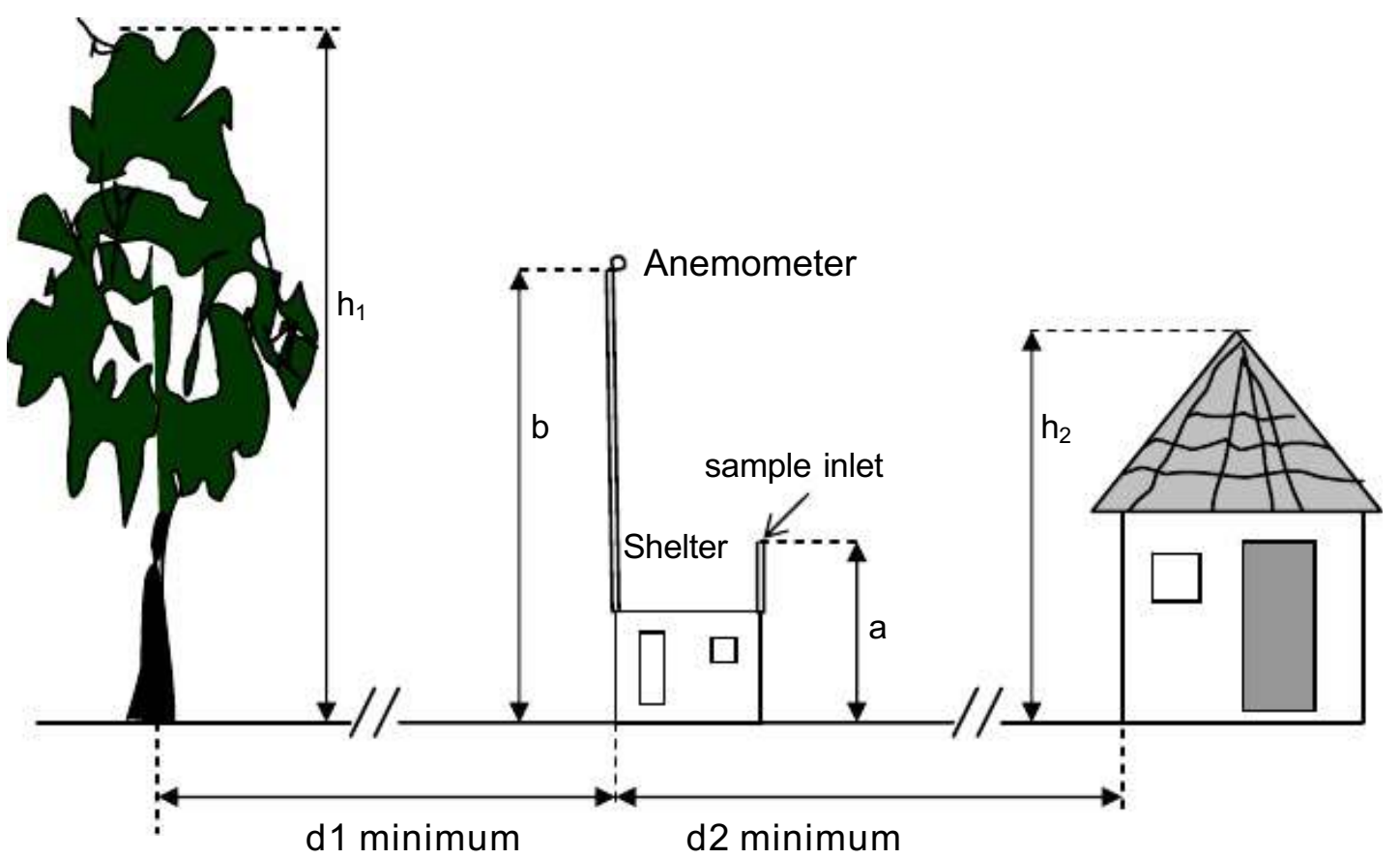

\section{Keterangan gambar:}

a adalah tinggi shelter $+0,5 \mathrm{~m}$ (minimal $3 \mathrm{~m}$ );

b adalah tinggi alat pemantau meteorologis (anemometer, $\mathrm{RH}$ meter etc) minimal 2,5 kali tinggi sampel inlet udara (minimal $10 \mathrm{~m}$ );

d1 adalah jarak dari pohon terdekat

d2 adalah jarak dari bangunan terdekat

h1 adalah tinggi dari pohon terdekat;

h2 adalah tinggi dari bangunan terdekat.

Gambar 3 Lokasi peralatan pemantau meteorologiss yang relatif jauh dengan bangunan atau pohon tertinggi 


\section{Lampiran A \\ (normatif) \\ Pelaporan}

Catat pada buku kerja hal-hal sebagai berikut:
1) Nama lokasi/jalan
2) Tanggal pengukuran
3) Nama petugas bangunan, pohon, jalan)
5) Data kondisi meterologi
6) Denah lokasi

4) Catatan fasilitas pemantauan (fasilitas sampling, jarak titik pengambilan contoh dari

CATATAN Lihat Lampiran B (informatif) 



\section{Lampiran C \\ (informatif)}

Hal-hal yang dianggap perlu dalam pelaporan

1. Nama stasiun

2. Mulai pengukuran (date and time)

3. Selesai pengukuran (date and time)

4. Lokasi pengukuran (nama jalan)

5. Jarak lokasi sampling (ambien air sampling inlet ) dari jalan, pohon dan bangunan

6. Jarak lokasi dan tinggi peralatan pemantau meteorologis dari jalan, pohon dan bangunan

7. Parameter yang diukur, termasuk status perawatan alat dan kalibrasi

8. Catat klassifikasi tipe jalan (lebar, sempit, canyon, toll atau yang lainnya, seperti persimpangan jalan, halte, perparkiran dIl)

9. Catat klassifikasi kepadatan lalulintas (dalam 3 klas: kurang dari 2000, 2000 - 10000, dan lebih dari 10000 kendaraan per hari)

10. Catat rata-rata kecepatan kendaraan dengan ketelitian $\pm 5 \mathrm{~km} / \mathrm{h}$

11. Catat komposisi kendaraan kecuali mobil penumpang dengan ketelitian $\pm 2 \%$

12. Catat jarak dari persimpangan terdekat yang mempengaruhi pengukuran

13. Catat radius lokasi yang mewakili titik sampling

14. Catat peta lokasi pengukuran 


\section{Bibliografi}

Hoggesunan Peraturan Tentang Pengendalian Pencemaran Udara. BAPEDAL 770- 0007Steinar Larssen, et al 1999. "Criteria for Euroairnet the EEA Air Quality Monitoring and Information Network". European Environmental Agency (EEA).

Soedomo M., 1999. "Kumpulan Karya ilmiah mengenai Pencemaran Udara", Penerbit ITB, Bandung

World Bank, 1997. "Urban Air Quality Management Strategy in Asia: Jakarta”, World Bank Technical Paper 379 


\section{LAMPIRAN B}




\section{DOKUMENTASI}

\section{B1. Vegetasi pada Studi Kasus (Jalan Prof Hamka dan Jalan Rasuna Said}

Kota Padang)

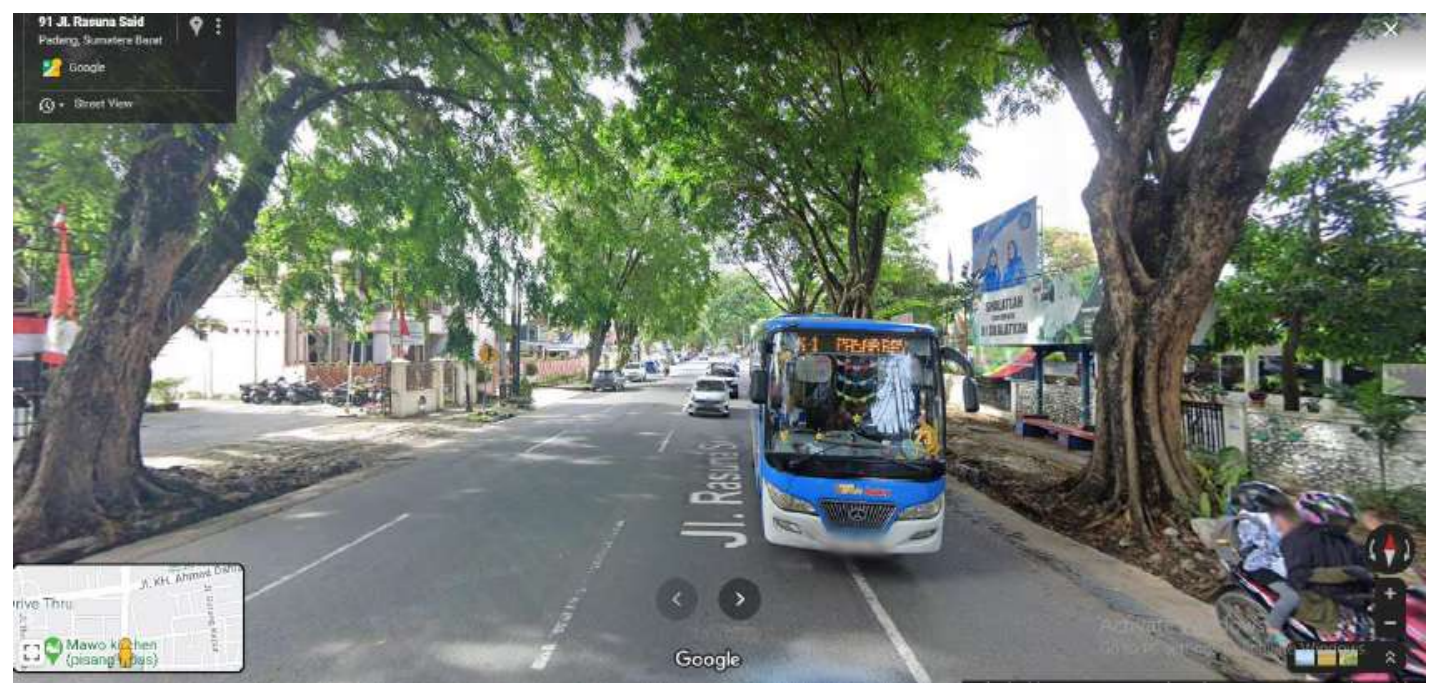

Gambar B.1 Dokumentasi Jalan Rasuna Said Kota Padang

(Sumber: Google Maps)

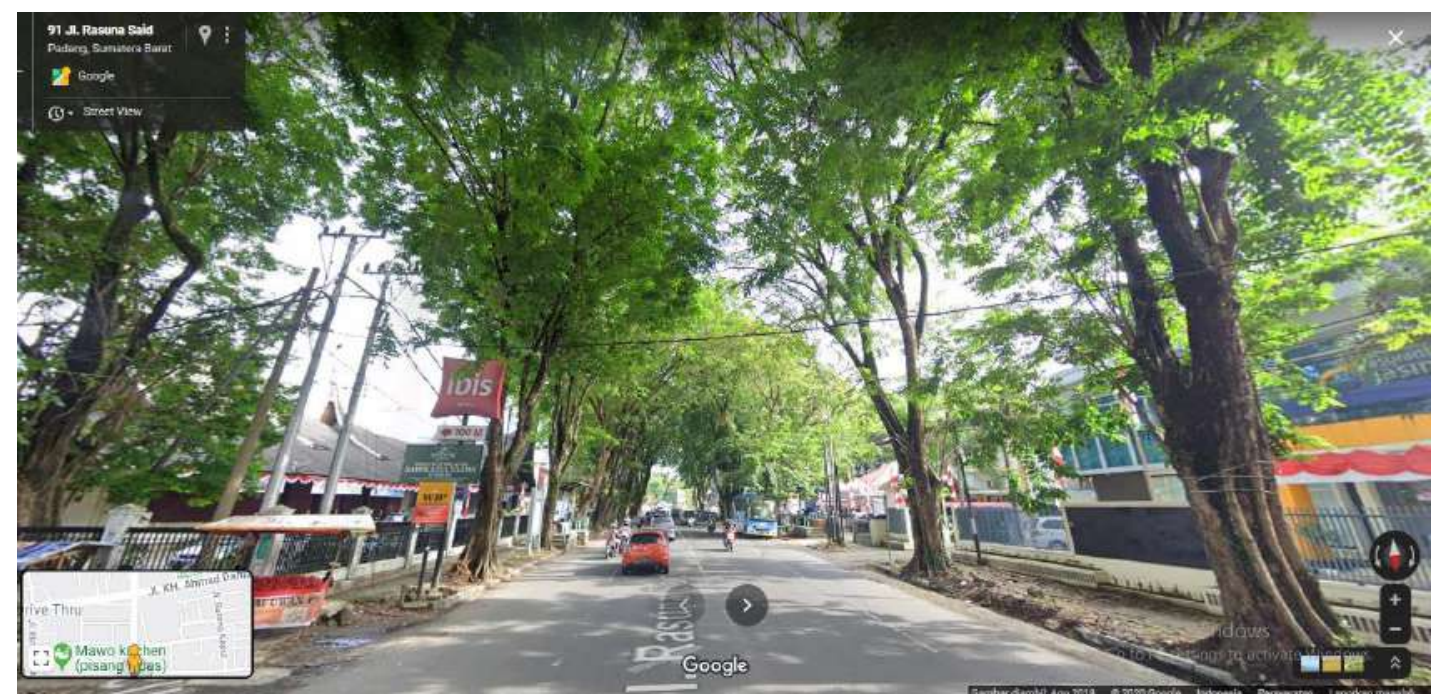

Gambar B.2 Dokumentasi Jalan Rasuna Said Kota Padang

(Sumber: Google Maps) 


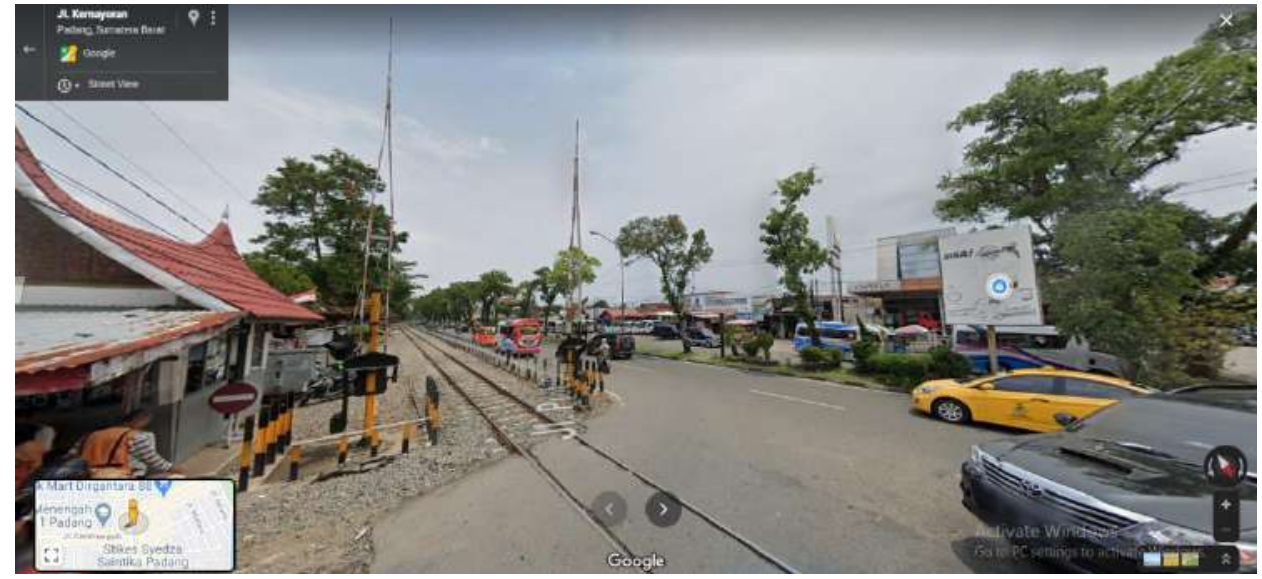

Gambar B.3 Dokumentasi Jalan Prof. Hamka Kota Padang (Sumber: Google Maps)

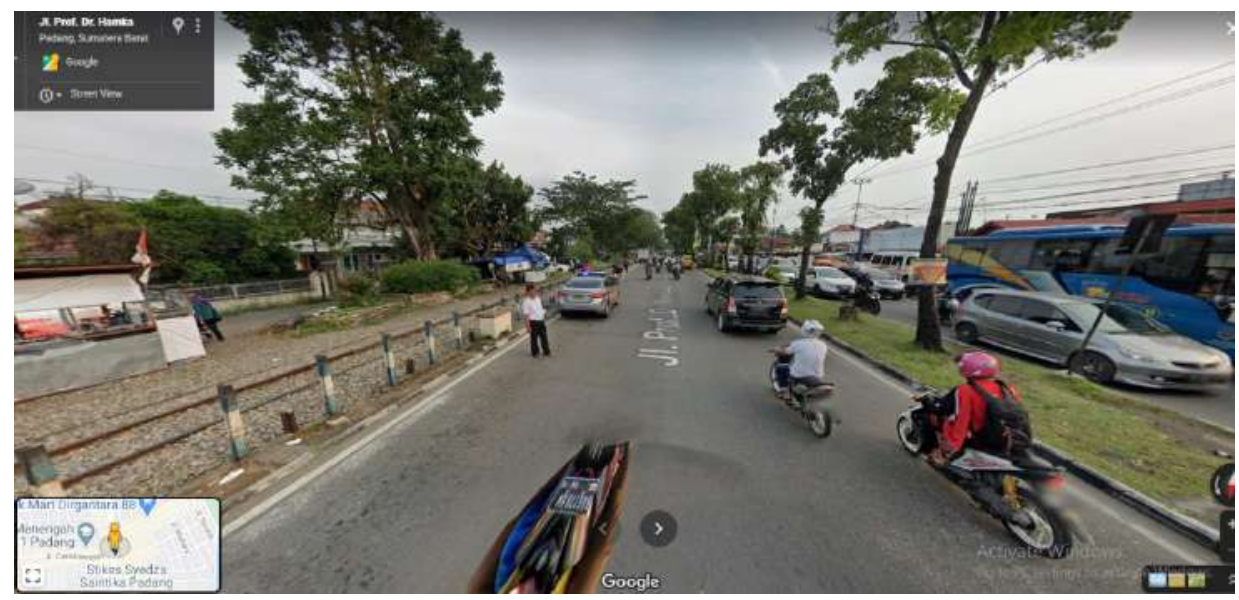

Gambar B.4 Dokumentasi Jalan Prof. Hamka Kota Padang (Sumber: Google Maps) 


\section{TA}

ORIGINALITY REPORT

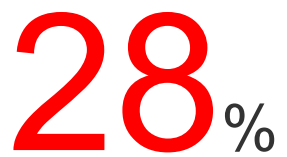

SIMILARITY INDEX
$28 \%$

INTERNET SOURCES
$1 \%$

PUBLICATIONS
$\%$

STUDENT PAPERS

PRIMARY SOURCES

1 media.neliti.com

Internet Source

2 repository.its.ac.id

Internet Source

3 eprints.upnjatim.ac.id

Internet Source

4 scholar.unand.ac.id

Internet Source

5 journal.ipb.ac.id

Internet Source

6 journal.unnes.ac.id

Internet Source

7 repository.radenintan.ac.id

Internet Source

8 lib.unnes.ac.id

Internet Source 
11 aryaarismaya.blogspot.com

Internet Source

12 etheses.uin-malang.ac.id

Internet Source

13 jurnal.universitaskebangsaan.ac.id

Internet Source

14 repository.usu.ac.id

Internet Source

15 docplayer.info

Internet Source

16 repository.ipb.ac.id

Internet Source

17 id.123dok.com

Internet Source

18 es.scribd.com

Internet Source

19 digilib.unimed.ac.id

Internet Source 
Exclude quotes

On

Exclude matches

$<1 \%$

Exclude bibliography

On 